Florida International University

FIU Digital Commons

$10-16-2020$

\title{
A Rising Regional Power: Making Sense of Ethiopia's Influence in the Horn of Africa Region
}

Yonas K. Mulat

ymula001@fiu.edu

Follow this and additional works at: https://digitalcommons.fiu.edu/etd

Part of the Comparative Politics Commons, and the International Relations Commons

\section{Recommended Citation}

Mulat, Yonas K., "A Rising Regional Power: Making Sense of Ethiopia's Influence in the Horn of Africa Region" (2020). FIU Electronic Theses and Dissertations. 4590.

https://digitalcommons.fiu.edu/etd/4590

This work is brought to you for free and open access by the University Graduate School at FIU Digital Commons. It has been accepted for inclusion in FIU Electronic Theses and Dissertations by an authorized administrator of FIU Digital Commons. For more information, please contact dcc@fiu.edu. 


\title{
FLORIDA INTERNATIONAL UNIVERSITY \\ Miami, Florida
}

\section{A RISING REGIONAL POWER: MAKING SENSE OF ETHIOPIA'S INFLUENCE IN THE HORN OF AFRICA}

\author{
A dissertation submitted in partial fulfillment of the \\ requirements for the degree of \\ DOCTOR OF PHILOSOPHY \\ in \\ POLITICAL SCIENCE \\ by \\ Yonas Ketsela Mulat \\ 2020
}


To: Dean John F. Stack, Jr.

Steven J. Green School of International and Public Affairs

This dissertation, written by Yonas Ketsela Mulat and entitled A Rising Regional Power: Making Sense of Ethiopia's Influence in the Horn of Africa, having been approved in respect to style and intellectual content, is referred to you for judgment.

We have read this dissertation and recommend that it be approved.

Felix Martin

Eric Lob

Hilary Jones

John Clark, Major Professor

Date of Defense: October 16, 2020

The dissertation of Yonas Ketsela Mulat is approved.

Dean John F. Stack, Jr.

Steven J. Green School of International and Public Affairs

Andrés G. Gil

Vice President for Research and Economic Development and Dean of the University Graduate School

Florida International University, 2020 


\section{DEDICATION}

I dedicate this work to my late father Ketsela Mulat who taught me the values of hard work,

humility and education

AND

to my son Amanuel 


\section{ACKNOWLEDGMENTS}

I am grateful to everyone who has helped me in my journey of becoming a Ph.D. First and foremost, I would like to express my sincere gratitude to my advisor, Prof. John Clark whose constant encouragement was vital to finish my studies. His patience and motivation helped me complete this dissertation. His deep knowledge of and love for Africa and its people have helped me during the research and writing of this thesis. I could not have imagined having a better advisor and mentor.

Besides my advisor, I would like to thank the rest of my thesis committee members Prof. Felix Martin, Prof. Hilary Jones, and Dr. Eric Lob, for their insightful comments and encouragement, but also for the hard question which motivated me to widen my research from various perspectives. Prof. Martin's care and advice went well beyond my dissertation, as he always inquired about my personal life and shared his valuable experience from his days as a Ph.D. Student.

Many thanks go to people at FIU and the Department of Politics and International Relations for their assistance with my studies. I would like to thank Dr. Shlomi Dinar for his insightful comments to the draft dissertation and his kind support in extending my PhD. Completion date. I also want to thank Dr. Clement Fatovic, Dr. Dario Moreno, Dr. Judith Stiehm, Dr. Tatiana Kostadinova, Dr. Roland Cox, Dr. Erin Damman, Dr. Danielle Clealand, Maria Wilkinson-Diaz, and Erika Posada. I also want to thank Maria Melendez-Vargas and Elva Molina for helping me navigate the institutional review board process. 
l'd like to thank my fellow graduate students: Fiacre Bienvenu, Nicolas Terradas, Bryant Sculos, Marc Mayo, Anand Shastri, Ahmad Mirtaheri, Arash Reisinzhad, Bibek Chand and Craig Lang for all the stimulating discussions and for all the fun we have had during the many busy times. My long-time friends and colleagues from Addis Ababa University - Demissie Fantaye, Alexander Vadala, Deresse Getachew - and Sebawit Bishu from FIU read and commented on the dissertation proposal.

I cannot begin to express my gratitude to my family for the love, support, and encouragement along this journey. Special thanks to my mother, Mulu Makonnen, for her prayers and love that sustains me throughout my life. I also want to thank my brother Samson, and sisters Frehiwot and Bethlehem, for their love and belief in my success. I am deeply indebted to Dr. Mekbib, Gera, Hirut and Teddy for being my loving family away from my home country. Last but not the least, I would like to thank my wife Kidist, for putting up with my long hours of research including weekends at the library. The completion of my education would have been unthinkable without her patience, understanding, and, most of all, love.

Finally, I am grateful to have had the privilege of attending Florida International University. This experience has afforded me the opportunity to work with some of the best and brightest, and the resources to achieve great success. Thank you for this opportunity. 


\title{
ABSTRACT OF THE DISSERTATION
}

\section{A RISING REGIONAL POWER: MAKING SENSE OF ETHIOPIA'S INFLUENCE \\ IN THE HORN OF AFRICA}

\author{
by \\ Yonas Ketsela Mulat \\ Florida International University, 2020 \\ Miami, Florida \\ Professor John Clark, Major Professor
}

This research investigates the conditions under which a state's regional influence increases, or a state becomes a regional power, using an in-depth analysis of the case of Ethiopia in the Horn of Africa. I make a two-fold argument (a) developments in the Horn of Africa over the last two decades show that the regional influence of Ethiopia has been growing, and (b) analysis of attributional capabilities - population, military, economy - alone do not fully explain this development. This dissertation tests a hypothesis derived from neo-classical realism recognizing that relative power (vis a vis the neighbors), although key to understanding both regional political standing and foreign policy, does not fully explain the rise of a regional power. I then use historical institutionalism to identify critical junctures in Ethiopia's history that have contributed to state capacity. The research capitalizes on qualitative secondary sources and archival data to identify critical junctures that (a) expanded Ethiopian identity from a northern core to a larger community and (b) identified the people of Ethiopia more strongly with the central state over time. I conclude that, the theoretical shift to national level 
institutional transformation and critical junctures explain external relations in a weak-states regional system as in the Horn of Africa where national borders are contested, nation-building projects are unfinished, and cross-border intervention in support of insurgencies is prevalent. 


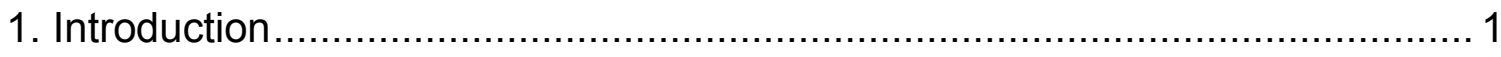

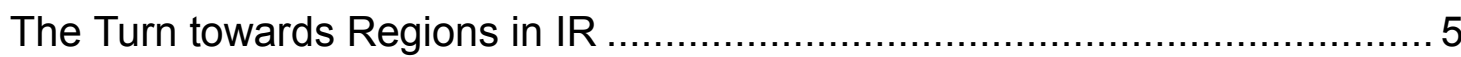

Regional Powers: State of the Research ................................................... 8

The Research Parameter: Horn of Africa as a Sub-region............................ 13

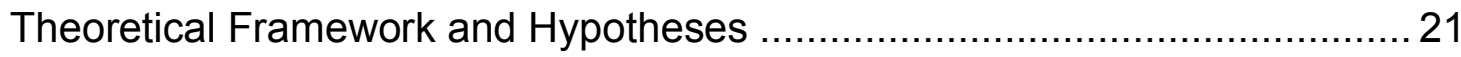

Methodology and Methods of Gathering Data ........................................... 27

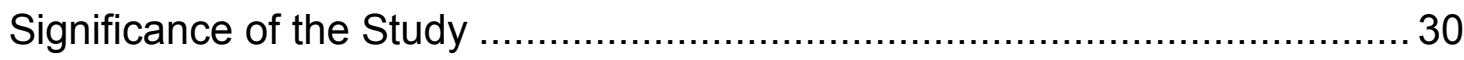

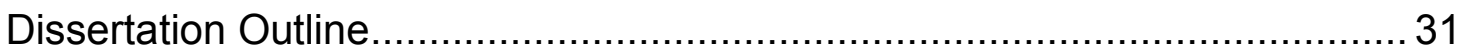

2. Ethiopia as a Regional Power - Bilateral Relations with Somalia and Eritrea . 33

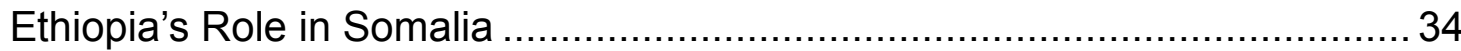

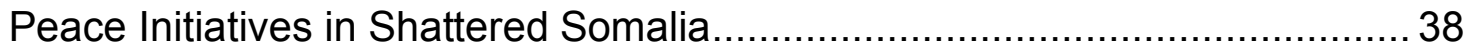

The Arta Peace Process and the TNG................................................... 43

The Eldoret/Mbaghati Peace Conferences and the TFG ............................ 47

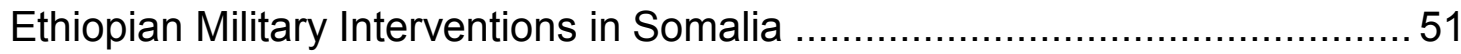

Ethiopia Relations with Eritrea: Military Defeat and Containment ...................61 61

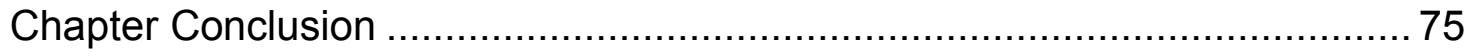

3. Ethiopia as a Regional Power - Projection of interest, Provision of public

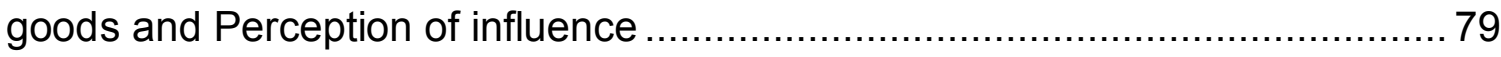

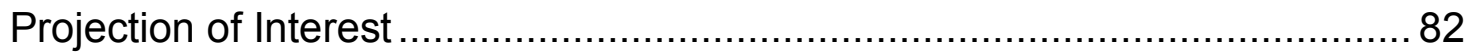

Projection of Ethiopia's Values: Federalism in Somalia ............................... 88

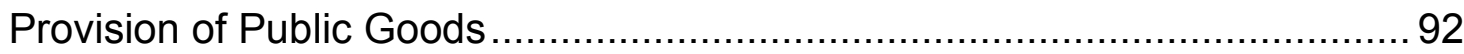

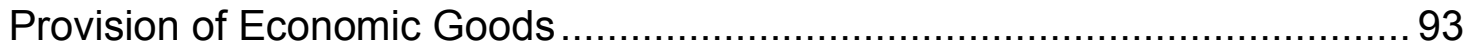

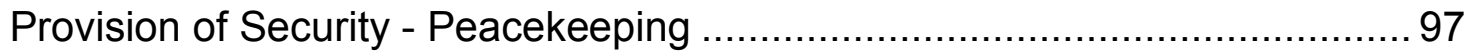

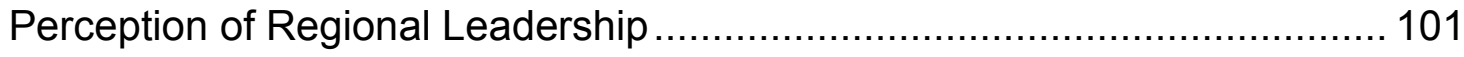

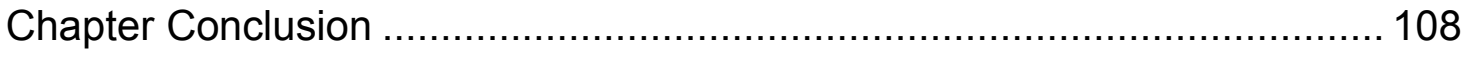


4. Analysis of the Distribution of Material Capabilities ................................... 111

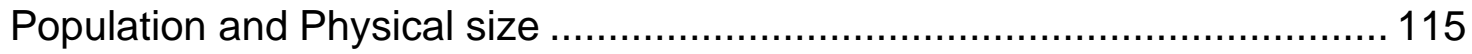

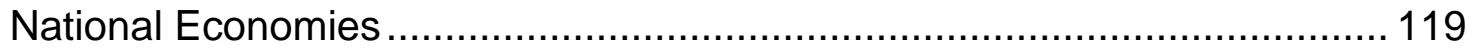

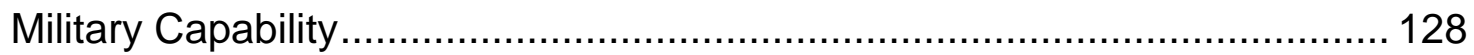

Chapter Conclusion: Ethiopia Punching Above Weight ............................. 135

5. A Historical Institutional Analysis of the Ethiopian State ............................ 137

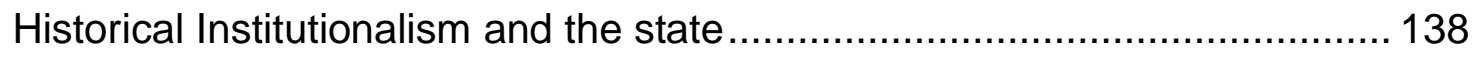

The Ethiopian State in a Historical Context.............................................. 144

Formation of the Modern Ethiopian State .............................................. 146

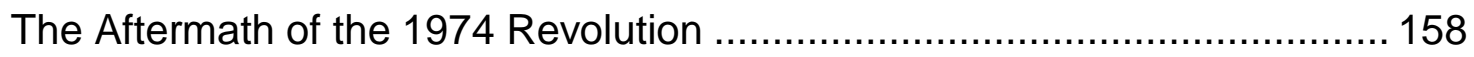

State Power under the EPRDF regime ................................................ 173

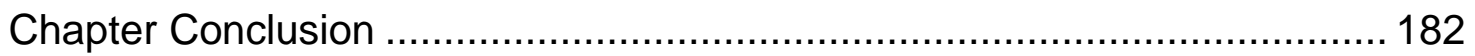

6. National Identity as a factor in Regional Standing .................................. 187

Implications of Adwa for Ethiopia's national identity................................... 192

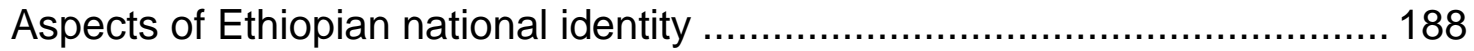

Adwa - Mobilization of National Identity in war ........................................ 194

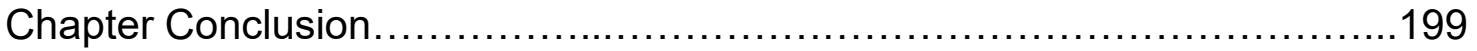

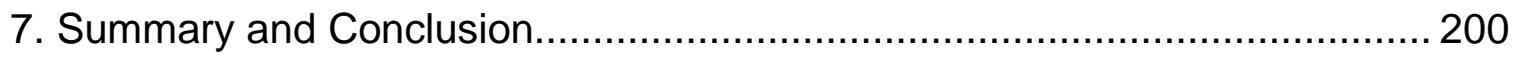

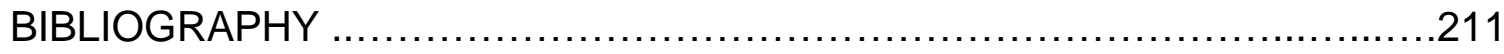

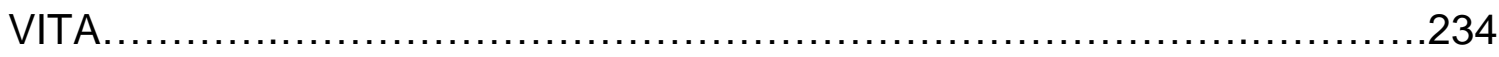




\section{LIST OF TABLES}

TABLE

PAGE

Table 1. Ethiopia's Power Stations $100 \mathrm{MW}$ and Above (Post 2000)...........94

Table 2. Ethiopian Peacekeeping Contributions..............................98

Table 3. Summary of Capability Variables by Various Authors................114

Table 4. Demographic Indicators - Horn of Africa (2015) ....................117

Table 5. Selected Economic Indicators - Horn of Africa (2015)..............120

Table 6. Total GDP-PPP - Horn of Africa (in billions USD 2015 value) .......122

Table 7. GDP Growth Rate (2006 - 2015) - Horn of Africa..................124

Table 8. Six Years GDP Forecast - Horn of Africa...........................125

Table 9. Ethiopia's Import and Export Horn of African (2015) „...............127

Table 10. Military Expenditure Horn of Africa Countries (2011-2016) ........130

Table 11. The Military Balance - Horn of Africa 2016......................131

Table 12. Selected_Rebel Movements in the last days of the Derg...........170

Table 13. Ethiopia: Population by Ethnicity ................................174 


\section{LIST OF ABBREVIATIONS}

AFRICOM United States Africa Command

AMISOM African Union Mission in Somalia

ARPCT Alliance for the Restoration of Peace and Counter Terrorism

ARS Alliance for the Re-Liberation of Somalia

ARS-D Alliance for the Re-Liberation of Somalia-Djibouti

ARS-A Alliance for the Re-Liberation of Somalia-Asmara

ASWJ Ahlul Sunnah wal Jamaa'h

AU African Union

AU-PSC African Union Peace and Security Council

CJTF-HOA Combined Joint Task Force - Horn of Africa

EPRDF Ethiopian Peoples' Revolutionary Democratic Front

EPLF Eritrean People Liberation Front

FDRE Federal Democratic Republic of Ethiopia

GWoT Global War on Terror

HoA Horn of Africa

IGAD Inter-Governmental Authority on Development

NFD Northern Frontier District

NRC National Reconciliation Conference

NSC National Salvation Council

OAU Organization of African Unity

OIC Organization of the Islamic Conference

OLF Oromo Liberation Front 


\begin{tabular}{ll} 
ONLF & Ogaden National Liberation Front \\
OPLF & Oromo People Liberation Front \\
PFDJ & People's Front for Democracy and Justice \\
RRA & Rahanwein Resistance Army \\
SDM & Somali Democratic Movement \\
SNA & Somali National Alliance \\
SNF & Somali National Front \\
SNM & Somali National Movement \\
SNRC & Somalia National Reconciliation Conference \\
SPM & Somali Patriotic Movement \\
SPM-O & Somali Patriotic Movement-Ogaden \\
SPM-H & Somali Patriotic Movement-HARTI \\
SRRC & Somalia Reconciliation and Restoration Council \\
SSA & Somali Salvation Alliance \\
SSC & Somali Salvation Council \\
SSDF & Somali Salvation Democratic Front \\
SSNM & Southern Somali National Movement \\
TFG & Transitional Federal Government (of Somalia) \\
TFI & Transitional Federal Institutions (of Somalia) \\
TFP & Transitional Federal Parliament (of Somalia) \\
TNG & Transitional National Government (of Somalia) \\
TPLF & Tigray People's Liberation Front \\
UIC & Union of Islamic Courts \\
\hline
\end{tabular}




$\begin{array}{ll}\text { UNAMID } & \text { United Nations Assistance Mission in Darfur } \\ \text { UNITAF } & \text { Unified Task Force } \\ \text { UNOCI } & \text { United Nations Operation in Cote D'Ivoire } \\ \text { UNOSOM } & \text { United Nations Operation in Somalia } \\ \text { UN-PKO } & \text { United Nations Peacekeeping Operations } \\ \text { UNPOS } & \text { United Nations Political Office for Somalia } \\ \text { UNSC } & \text { United Nations Security Council } \\ \text { USC } & \text { United Somali Congress } \\ \text { USC/SSA } & \text { United Somali Congress Salvation Army } \\ \text { USC/SNA } & \text { United Somali Congress Somali National Alliance } \\ \text { WSLF } & \text { West Somali Liberation Front }\end{array}$




\section{Introduction}

Despite a long history of independence and statehood, Ethiopia has suffered repressive military rule, catastrophic civil war, and drought and famines of biblical proportions over the past half century. As a result, the dominant image of Ethiopia has been that of a war-torn, impoverished country epitomized by recurrent droughts and famines. Yet, since the turn of the $21^{\text {st }}$ century, Ethiopia has recorded rapid economic growth, and has emerged as a beacon of stability in the turbulent Horn of Africa. Consequently, it has gained increasing strategic importance in the region. Ethiopia is thus increasingly described as a regional power given its military and diplomatic clout, demographic size, and increasing engagement in regional peace and security issues that indicate the will to lead and influence the region (Kidist 2014; Le Gouriellec 2018; Felter 2018; Dehez, 2008; Cheru et al 2017; Zahorik 2014; Verhoeven 2015; Nelson 2016).

This dissertation investigates the phenomenon of Ethiopia's emergence as a regional power in the Horn of Africa sub-region. During the Cold War, research in international security has been dominated by superpower competition with a secondary place given to regions and regional powers. To the extent that regions were the subjects of the study of international security, primacy was given to the scale of interest in and penetration of specific regions by the respective superpowers, and by former colonizers, and how these impacted regional peace and stability. In recent times, however, the place of regions in International Relations (hereafter IR, or the field that studies international relations) has 
attracted greater attention. The region as a unit of analysis has progressively acquired theoretical and empirical weight as an expression of interests and interactions at a level above the state and below the international (Buzan and Waever 1991). The growing regionalization of international politics has been attributed to the end of the Cold War, retreat of the superpowers, fading US global interest and hegemony in distant regions, and the supposed inability of the Westphalian state to address cross-border problems. These changes have led to concomitant challenges that are beyond the capacities of individual states and that require concerted effort—and leadership—at the regional level.

Within the broader corpus of literature on regions and IR, a wide debate has surfaced on how regional powers affect regional security structures and the success (or lack thereof) of regional integration, or how they interact with powers at the global level. The growing importance of regional power centers is predicated on the view that the end of the Cold War and retreat of global powers has enabled regional powers to exert their influence in their respective zones. More specifically, inquiries on regions and powers have mainly focused on how the existence of regional powers, and the nature of their regional leadership, taken as independent variables, impact regional outcomes such as security architectures, regional peace and stability, or the success or failure of regional integration schemes.

This research investigates the conditions under which a state's regional influence increases, or a state becomes a regional power, by using the case of 
Ethiopia in the Greater Horn of Africa ${ }^{1}$. The claim that Ethiopia has a unique place in African history has somewhat become conventional. During the Imperial and Derg $^{2}$ regimes, consigned to the annals of history in 1974 and 1991, respectively, Ethiopia had assumed active continental and sub-continental roles. For example, that Ethiopia is one of only two Sub-Saharan African countries (the other being Liberia) to have never been colonized is often cited as a source of its soft power. More importantly, this has enabled Ethiopia's significant international presence including membership in the League of Nations (LoN), and later the United Nations (UN) in which Ethiopia was one of three African founding members including Egypt and Liberia.

Moreover, the Ethiopian government, and Emperor Haile Selassie ${ }^{3}$ personally, played an instrumental role in the formation of the OAU. The capital Addis Ababa has been serving as the seat of first the Organization of African Unity $(\mathrm{OAU})$ and later its successor, the African Union (AU), and UN-Economic Commission for Africa (ECA). Ethiopian troops were part of the UN peacekeeping forces in Korea (1950-53) and the Congo (1960). Additionally, Ethiopia had provided military and diplomatic support for the decolonization of African countries and the end of white minority rules in Zimbabwe and Apartheid South Africa.

\footnotetext{
${ }^{1}$ In this dissertation the "Horn of Africa" and "the Horn" will be used interchangeably.

${ }^{2}$ Derg, meaning Committee in the local parlance, is often used to refer to the military regime which was headed by Col. Mengistu Hailemariam and ruled Ethiopia for seventeen years from 1974 until 1991.

${ }^{3}$ Emperor Haile Selassie ruled Ethiopia from 1930 to 1974.
} 
Despite such potential for regional leadership and clout, neither regime managed to impose their authority over the Horn of Africa, much less emerge as a regional power. The country has been beset by crippling internal political and economic problems. Secessionist movements in Eritrea and the Ogaden region, inhabited by Ethiopian Somalis and subject of irredentist claims by Somalia, sapped the resources of the state and provided regional competitors an opportunity to intervene and weaken the Ethiopian state. However, in contrast to previous governments, the current regime of the Ethiopian Peoples' Revolutionary Democratic Front (EPRDF) that came to power in 1991 through military victory has arguably been successful in projecting its influence regionally. This dissertation seeks to analyze the sources of this growing influence.

Thus, this study addresses the core question, what are the factors that contributed to Ethiopia's rise as a regional power in the Horn of Africa? I begin with the argument that Ethiopia has actually, if gradually, attained the status of a regional power and has been able to shape outcomes in regional politics. The structure of power relationships in the Horn of Africa is still in transition and may not be characterized by the preponderance of a single country à la Nigeria and South Africa in West and Southern Africa, respectively. However, Ethiopia has a disproportionately greater involvement in regional politics.

To the extent that Ethiopia has become a regional power under the EPRDF, the dissertation attempts to determine whether this could be attributed to (a) the regional distribution of material capabilities (economic and military power vis-à-vis its neighbors) or factors at the national or domestic levels including (b) institutional 
development in aspects of evolution of the Ethiopia state or (c) Ethiopia's sense of national identity and historical importance, which imbues the population with a commitment to acting as a regional power. In other words, the study attempts to determine whether internal variables are essential for the emergence of regional power, or whether regional powerhood can be abstracted only from the distribution of power capabilities across countries in the Horn of Africa. The answer to this question, in turn, will show the region as a viable level of analysis in the debates on regionalism in IR.

\section{The Turn towards Regions in IR}

Since its emergence as a distinct subject of inquiry in the aftermath of the First World War, IR has largely been dominated by state-centric or system-centric approaches of the classical and neo-versions of realism and liberalism. Having said that, dividing the international system into regional subsystems has also been a fairly common tradition, and some of the literature in IR, in particular in the field of area studies, have been based on regions as their basic unit of analysis or subject matter. But much of the study of regions during the Cold War gave primacy to the extent of interest in and penetration of specific regions by the respective superpowers, and by former colonizers, the implications on regional peace and security.

A focus on regions as the building blocks of the international order, however, regained momentum chiefly in the "new regionalism" in the field of economic integration literature in the wake of the end of the systemic constraints 
of the Cold War. The end of the bipolar international structure led to a revival of the region while increasing the scope of action of any potential hegemon in a particular region (Hentz and Boas 2003; Wilson and Sherwood 2000; Lake and Morgan 1997). Scholars of regionalism see world regions as the fundamental driving forces of world politics or the constituent parts of international relations. Although "not all international relations scholars are going to be persuaded of the centrality of regions in world politics" (Archaya 2007:4), the general awareness is that the revival of regionalism is a significant trend in the International Relations literature.

Regions particularly have gained analytical purchase in international political economy (or more specifically regional economic integration schemes) and, more germane to this dissertation, in security studies. A number of scholars have addressed security within specific regions including Africa (Keller and Rothchild 1996), the Middle East (Ayoob 1986), Asia (Acharya 2001), and Europe (Hodge 1999). Ayoob (1995) concludes that using the region as a level of analysis in security studies allows an additional level between the international and the state, simultaneously independent of, but affected by, security at the state and global levels.

Perhaps the most consistent attempt to understand the region as a distinct and organic unit in security studies has come from Barry Buzan and his colleagues (1983, 1991, 1998, 2003). Buzan highlights the importance of regions on the grounds that security threats are likely to travel more easily over "short distances than over long ones" (Buzan 2003:12). This is even more so in the case of weak 
states whose security concerns emanates from their neighbors, whose priorities realistically extend to their immediate environs, and whose economic ties with their immediate neighbors are strongest.

Buzan and Waever define a regional security complex as "a group of states whose primary interests link together sufficiently closely that their national securities cannot realistically be considered apart from one another" (1991:190). They brought together the regional approach in IR and security studies in a comprehensive tome (2003) in which regions were conceptualized as internally interdependent but mutually exclusive security complexes and "the level where states or other units link together sufficiently closely that their securities cannot be considered separate from each other" (2003:43). Buzan and Waever apply the regional level to identify regional security complexes in Asia, Europe, the Americas, Africa, and the Middle East ranging from weak proto-complexes - such as East and West Africa - to highly articulated super-complexes - as in the case of Asia.

In another major work, Peter Katzenstein (2005) argues that the preferences of the US, the sole superpower that really matters and has the resources to maintain a global presence, are critical to the shape and functioning of all regions. However, Germany and Japan, which he identifies as the "core states," play a vital role in this hegemonic order by providing "steady support for American purpose and power while also playing an important role in the regions affairs" (Katzenstein 2005:237). A dual hierarchy emerges between the U.S. imperium and the core states (Germany in Europe and Japan in Asia), and 
between the latter and others in their respective regions. Regions here are conceptualized as distinctively institutionalized but "porous" spaces hierarchically linked with the core states under an overarching U.S. imperium. Regions are made porous by globalization and by the extra-regional connections of states within them. Yet, over the medium term, the fate of security in most world regions is more heavily impacted by intra-regional relations than by outside intervention from further afar.

\section{Regional Powers: State of the Research}

As specified above, this dissertation deals with a common and important question that in recent years has attracted considerable interest both in academic and policy-making circles - that of the emergence of regional powers. A survey of the literature on regional powers reveals several distinct currents. First, although various measurements of power have been applied in determining which countries have become a regional power or hegemon, the major tendency is to favor objective material capabilities relative to other states in the region rather than ideational criteria, ${ }^{4}$ such as self-perception or ascription by other actors. Second, the list of powerful states whose influence in their respective regions are unparalleled seems to remain the same, further illustrating a degree of continuity in the selection criteria.

\footnotetext{
4 These include material, military and motivational factors (Myers 1991); economic (GNP), military development (defense expenditure), and demographic factors (Godenhardt and Nabers 2011); and more comprehensively, relative population size, GDP, GDP/capita, Composite Index of National Capability (military personnel, military expenditure, national energy consumption, nominal urban population, nominal total population), military spending, and military spending as a proportion of GDP (Ingersoll and Fraiser 2012).
} 
Third, most writers begin with an implicit assumption that these countries have already become regional hegemons, or have the wherewithal to achieve the status, without delving into the circumstances (especially internal) that either contributed to their rise as regional powers, or, in some cases, that led to their decline from that status. Fourth, in terms of structure, most of the works, with the exception of few recent books, are edited volumes of case countries which focus on specific geographical areas like the Middle East (Furtig 2014) or along thematic issues including regional powers and threat perception (Myers 1991), typologies of regional leadership (Flemes 2010; Osterud 1992); regional powers and the type of regional orders they build (Godenhardt and Nabers 2011; Lake and Morgan 1997); and regional powers and global redistribution (Nel, Nabers, and Hanif 2015).

In one of the earliest edited volumes on the subject, Oyvind Osterud characterizes "regional great powers" as countries that not only exercise unequalled influence within their respective regions, but might also be 'great power on a world stage' (in Neumann 1992:12). The contributors to this volume acknowledge that which states qualify as regional great powers depends on the particular criteria used in a specific time, the aspirations of the political elite as manifested in their foreign policies, and on the different sectors that contribute to a nation's capabilities. Moreover, different states might be seen as enjoying, or aspiring towards, regional power status and the status may actually prove temporary. 
The case studies in the volume edited by Neumann illustrate the nature of regional leadership and develop a typology of regional "powerhood" of a selected number of countries - Brazil, India, Indonesia, Poland, South Africa and Vietnam. Brazil, for instance, cannot be seen as a regional great power because the government places low priority on expanding its international influence directly but seeks to increase its economic power on the global stage. Indonesia qualifies as a regional power in terms of political impact but comes short on economic measures; whereas Vietnam has failed to exert regional influence except at the military level. Israel and (apartheid) South Africa succeeded in dominating their respective regions, but this came at the cost of hostile relations with their regional neighbors. Poland, curiously identified as a regional power in the interwar period, has lost its status mainly due to World War II and Soviet influence afterwards.

Daniel Flemes' edited volume (2010) considers the foreign policies of eight countries that have achieved, or aspire to achieve, a regional power status - Brazil, China, India, Iran, Israel, Russia, South Africa and Venezuela. The conceptual framework offers contending measurements of hegemony and leadership. Douglas Lemke looks at material capabilities of regional powers, whereas Dirk Nabers offers an account of how leadership and hegemony are not necessarily determined by material capabilities and hard power but may be exercised differently in the context of different regional settings.

The case studies illustrate how much the leadership credentials of different regional powers vary. Brazil practices "middle powermanship" and is ultimately not convincing as either a regional or global player; India seems to consciously avoid 
a dominant regional role, except through an extension of its global policy; South Africa has developed a strong regional policy at different levels in which the concept of responsible power is blended with that of a "southern power" that challenges Western/U.S global hegemony (van der Westhuizen cited in Godehart and Nabers 2011). The status of Israel, Iran, and Venezuela seems to be more a case of aspiring regional powers and mostly conferred by mainly the Western countries as a hope (Israel) or apprehension (Iran and Venezuela).

As an indication of the growing institutionalization of the regional powers research agenda, the German Institute of Global and Area Studies (GIGA) at University of Hamburg in Germany introduced a research initiative and a graduate program in 2007. The research agenda of this research program provided the most comprehensive and oft-used defining characteristics of regional powers - that regional powers have to be part of the geographically delimited region, ready to assume leadership, in possession of the necessary material and ideational capacities to do so, and consequently are highly influential in their region (Flemes and Nolte 2010).

Some of the recent books on the subject of regional powers have been authored by scholars affiliated to the GIGA research program. These works exhibit deeper analytical rigor and theoretical depth, indicating the growing sophistication and in-depth knowledge of the topic. In terms of methodology two books have continued in the tradition of the edited volume format - one by Godehardt and Nabers 2011 cited above and another by Furtig (2014) which analyzes the absence of a regional hegemon in the Middle East). A third book compares the 
leadership style of three powers - Russia, Brazil and India - located in different regions (Ingersoll and Fraizer 2012), and a fourth one is a case study of South Africa (Schlovin 2014).

Godehardt and Nabers (2011) develop a theoretical framework to understand the role of regional powers in creating and maintaining regional security orders. They begin with the assertion common to all scholars of regions as a consequence of the retreat of the global powers since the end of the Cold War, international security dynamics are less fathomable without considering the regional level as a primary focus for most states. These security dynamics, which include the identification, management and prevention of security threats, are in turn heavily influenced by regional powers.

Using the concept of Regional Security Complexes, Godehardt and Nabers (2011) address how security orders are defined and how regional powers are identified. They then turn their focus to an analysis of how the roles ${ }^{5}$ and foreign policy orientations ${ }^{6}$ of regional powers, conditioned by material capabilities, affect the identification of a regional power and development of regional security orders. Not all states with superior resources will assume the role of a regional power and, when they do, the security orders they engender differ from one power to the other. They identify five types of regional security orders - hegemonic, strength-based,

\footnotetext{
${ }^{5}$ They identify three roles regional powers with the requisite material capabilities might assume leadership, custodianship and protection.

${ }^{6}$ Orientations are defined as 'inclinations, dispositions or preferences of a state with respect to the development and maintenance of the security order' and comprises three types - status quo/revisionist, unilateral/multilateral, proactive/reactive.
} 
concert, integration, and unordered (where a regional center of power is absent). A comparative analysis of Russia in Central Asia (hegemony-based), Brazil in South America (concert-based) and India in South Asia (strength-based) within their own security complexes demonstrates an application of the framework.

My research topic fits into the growing research program on regional powers, a program that "refers to regional power hierarchies and places the focus on the question of whether a regional power exists in the corresponding regions, what the reasons for that are, and what the implications of its existence or absence are" (Nolte 2010). This study contributes to this research program by investigating the conditions under which a country becomes a regional power rather than taking that status as a given. It reverses the order in a manner of speaking, takes a step back and investigates the conditions under which a potential regional power can evolve into or emerge as an actual regional power. The case of Ethiopia and the Horn of Africa is interesting as the region is undergoing a transformation. Even though the Horn of Africa has had no apparent center of power, an incipient but still inchoate regional security architecture is taking shape at the center of which Ethiopia is increasingly assuming an active part. Aside from enriching our knowledge of the specific region, the study has broader significance to the regional power research and international relations theories.

\section{The Research Parameter: Horn of Africa as a Sub-Region}

Although the study of regions corresponds to the significance of regions to contemporary international order, differences emerge on the question of what 
regions are. Geographical contiguity is an essential part of the definition of a region. However, cultural, economic, or political ties also determine what constitutes a region or a sub-region. Moreover, with the recent advent of constructivism in IR, proximity or shared cultural, political, or economic ties are no longer considered sufficient for "region-ness." Regions are increasingly viewed in nongeographic, ideational terms "in terms of purposeful social, political, cultural, and economic interaction among states which often (but not always) inhabit the same geographical space" and collective identities, self-generated or recognized as such by outsiders (Adler et al 2006). For the purpose of this research, I will use the attributes of regional subsystems identified by Thompson (cited in Ayoob 1995:56) as "geographic proximity, regularity and intensity of interaction between actors to the extent that a change at one point in the subsystem affects other points, internal and external recognition of a group of states as a distinctive area, and a size consisting of at least two or probably more actors".

The Horn of Africa, the geographical focus of this study, has seen a high share of the scourge of violence even by African standards. Over the last several decades, the region has witnessed radical social revolutions (Ethiopia 1974 and 1991), regular cross-border interventions, two full-scale inter-state wars (EthiopiaSomalia in 1977, Eritrea-Ethiopia in 1998-2000), and countless intrastate conflicts leading to the secession of two states (Eritrea and South Sudan - three if we include the de facto state of Somaliland) and the collapse of another (Somalia). Countries in the region are among the poorest in the world and suffer from 
perennial humanitarian crisis including drought and famines of biblical proportions.

The region seems to epitomize a Hobbesian state of nature.

In geographical terms, the Horn refers to the Northeastern part of Africa that protrudes into the Indian Ocean in the Southeast and straddles the Red Sea in the Northeast. Conventionally, it comprises the key states of Ethiopia, Somalia and Djibouti, Sudan, South Sudan and Kenya. The term Greater Horn, however, is often used to include Uganda and other countries in the immediate vicinity like Egypt, Libya and Yemen often involve regional issues with implications on regional power balance ${ }^{7}$. Sudan got its independence in 1956; Kenya in 1963; Djibouti in 1977; British Somaliland and Italian Somaliland joined to form Somalia in 1960; while Eritrea was federated with Ethiopia in 1952 and gained its independence in 1993 after a three-decade long armed struggle leaving Ethiopia landlocked.

As a geographically large and diverse continent, Africa does not present a plausible scope for an aspiring regional power. In fact, in a weak state system where the capacity of state actors is constrained, it is often the sub-region that serves as the geographical platform to extend a state's influence. Arguably, only South Africa enjoys the requisite resources to harbor ambitions of continental

\footnotetext{
${ }^{7}$ The role of external actors in a regional security complex remains a point of difference. According to Lake and Morgan (1997) geographical contiguity should not necessarily be criteria for membership of a regional security complex and countries with significant interest and involvement in should be considered part of the regional complex even if geographically they are not part of the region. According to this view, the USA is an integral part part of the Middle East regional Security complex. Buzan and Waever (2003:80) reject Lake and Morgan's conflation of the global and the regional and the treatment of global powers as parts and members of the regional security complex. For them, geographical proximity is an essential factor of a regional complex and outside involvement comes in the form of either intervention or outlay. Outside powers always retain the option to exit and the degree of their commitment to the region heavily depends on domestic political considerations. Regional countries have no option of exiting from the complex and have to sink or swim together.
} 
leadership. This holds true in the case of the Horn of Africa and Ethiopia whose security threats emanate regionally and whose impact are realistically restricted to regional relations.

However, subdividing Africa into its sub-regional components is problematic and several alternatives exist. Institutions such as the World Bank and the International Monetary Fund (IMF), and the US Government commonly separate Sub-Saharan Africa (SSA) from the Arab countries of North Africa, which for geocultural and political purposes, are grouped together with the Middle East forming Middle East and North Africa (MENA). The United Nations Statistical Office on its part divides Africa into five sub-regions - Northern, Eastern ${ }^{8}$, Western, Central and Southern.

Alternatively, the various regional organizations have different arrangements and composition. The Intergovernmental Authority for Development (IGAD), the major regional organizations, comprises Djibouti, Eritrea, Ethiopia, Kenya, Somalia, South Sudan, Sudan and Uganda. On the other hand, the East African Standby Force (EASF), an integral part of the African Standby Force (ASF) of the AU's new African Peace and Security Architecture (AU-PSA), adds Burundi, Rwanda, Seychelles and the Comoros Islands to the IGAD member states. By the same token, the Nile Basin Initiative (NBI), the hydro-political regime promoting cooperation among riparian states of the Nile river, includes Tanzania and the

\footnotetext{
${ }^{8}$ More pertinent for our purpose, the Eastern African regions according to the UN statistical office comprises a comprehensive list of countries that include the IGAD members plus countries normally associated with Southern or Central Africa including Rwanda, Burundi, Zambia, Tanzania, Zimbabwe, Malawi, and Madagascar ( http://unstats.un.org/unsd/methods/m49/m49regin.htm ) .
} 
Democratic Republic of Congo (DRC) and, more importantly, brings Egypt into the regional geopolitical equation.

\section{Map 1. The Horn of Africa Region}

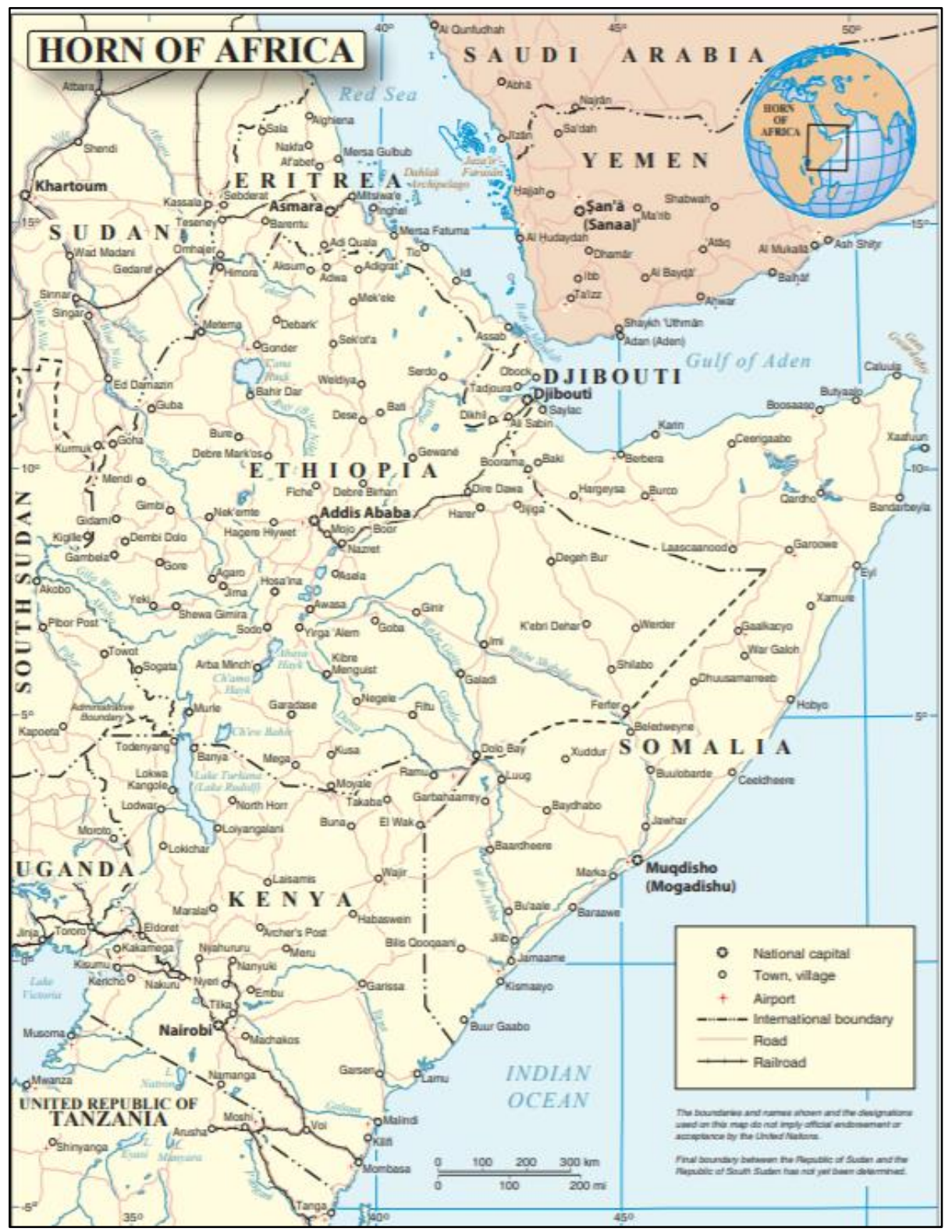

Source: United Nations (2012)

Such overlapping and often competing regional representations complicate the geographical parameters of the research. The EASF is critical because it is one 
arena where the low-key competition between Kenya and Ethiopia for regional influence plays out. The NBI and the Nile river basin in general is critical for Egypt because an uninterrupted flow of the water is a matter of survival and national security. As the source of $86 \%$ of the river flow, it is not surprising if Egypt views Ethiopia's growing regional influence with consternation. In fact, Egypt is more likely to attempt to preempt Ethiopia's growing regional sphere of influence arguably even more than the two competitors, Sudan and Kenya.

Notwithstanding these caveats, this research will primarily focus on the IGAD member countries. Inter-Governmental Authority on Drought and Desertification (IGADD) was formed in 1985 in the aftermath of severe drought and attendant famine in the region to facilitate food security and combat climate related risks (Yihun 2014). After its' reorganization as IGAD in 1994, and despite the inclusion of 'development' in its name, it played significant role in regional security including in negotiating the civil wars in Sudan and Somalia and, after its independence, in the civil war in South Sudan. IGAD's extensive part in regional conflict and security brought all members including Uganda and Kenya, whose foreign relations has been influenced by their interest in Central Africa (Great Lakes Region) and Eastern Africa. Using IGAD membership as defining the region, therefore makes sense.

Turning to the security structure, Buzan and Waever (2003:242) regard the Horn as a pre-complex and identify three factors that militate against its emergence as a fully developed regional complex. First, they claimed the security problems affecting countries in the region are unrelated and there is the lack of notable 
linkages between the Ethiopia-Somalia security dynamic on the one hand and the Ethiopia-Eritrean security dynamic on the other. Secondly, they contended that insular states that delineate the regional security complex and avoid overlaps with other ones, one of the criteria demarcating a pre-complex from a well-defined one, do not exist. In terms of the polar structure, Buzan and Waever argue the Horn of Africa is multipolar with no center of power or regional hegemon that can exercise unparalleled influence. By the same token, Ingersoll and Fraizer (2012) characterize the region as 'unordered' with no clear concentration of power, roughly equal distribution of material capabilities among Sudan, Ethiopia and Kenya and an absence of a clear pattern of leadership among these countries. None of the books discussed in the literature review identify a regional power in the Horn of Africa.

With regards to the question of regional hegemony in Africa, Jeffrey Herbst identifies Nigeria, South Africa, Ethiopia and the DRC as countries with the potential for regional dominance as they have the largest population size and command the largest armies on the continent. However, Herbst argues only Nigeria and South Africa are more likely to emerge as regional hegemons. Meanwhile, the DRC "cannot project power over its own territory, much less into in to other countries, in a professional and unbiased manner" and "[G]iven its profound poverty and ethnic divisions, Ethiopia also cannot play the disinterested big brother" (Herbst 2000:314).

As I pointed out above, much has changed in the past twenty years, however, since Herbst made his argument in 2000, when Eritrea and Ethiopia were 
mired in a bloody war. Despite the deterioration of political openness, the Ethiopian government is often praised for a record of economic growth and poverty alleviation, and for maintaining internal political stability in a turbulent corner of the world. The EPRDF government of Ethiopia is a chief ally of the US in the Global War on Terror (GWOT). More significantly, as stated above, Ethiopia has been exerting its influence in its neighborhood with some success. I explore these questions further in the chapters below.

A cursory assessment of Ethiopia's post-1991 regional policy and relations exhibits both continuity and changes. The core interest remains the maintenance of regime and national security, often conflated as one and the same. But the Ethiopian government has pursued a proactive regional policy and has been able to project its influence more than the previous regimes were able to do. The Ethiopian National Defense Forces (ENDF) engage actively both in war (Eritrea and Somalia) and in peace (Abiyei, South Sudan, Darfur, and Somalia). Plus, Ethiopia is the largest troop contributor of UN and AU peacekeeping operations. ${ }^{9}$ Furthermore, Ethiopia is at the front of mediation efforts in Somalia and South Sudan and has been able to shape the outcomes of peace negotiations as in the formation of Somalia's Transitional Federal Government (TFG) in 2004. Incipient designs can also be discerned to shape the regional political landscape and create a region in its image. Ethnic federalism in Ethiopia could potentially serve as an

\footnotetext{
${ }^{9}$ As of June 2020 Ethiopia is the largest troop and police contributor to UN peacekeeping missions with 6,638 troops, police and military advisors. Moreover, almost all 4,000 members in United Nations Interim Security Forces in Abiyei (UNISFA) including the Force Commander, come from Ethiopia. (United Nations 2020)
} 
ideational template to address identity-based tensions. Ethiopia has been accused of pushing for an ethnic federalism in South Sudan as part of the ongoing negotiation; Ethiopia provides support for ethnic-based Eritrean opposition groups; and the TFG in Somalia adopted a federal state structure. The puzzle thus lies in the fact that, despite the precarious redistributive economic system and inherent challenges of domestic political consolidation, Ethiopia has been relatively effective in projecting its influence in the region. The next part proposes tentative conjunctures to this puzzle using theories of IR.

\section{Theoretical Framework and Hypotheses}

Theories of international politics have been dominated by realism and neorealism according to which the structure of polarity at the global level, or by extension of that of a region, is derived from the distribution of power or material capabilities among its constituent states. As the foregoing review of literature on regional powers stipulates, the existence (or absence) of a preponderant power in a region takes into account access to resources; size of population; geopolitical variables such as location and physical size of a country; military indicators including size of military and military expenditure; and various economic pointers including GDP, GDP per capita, industrialization and urbanization. According to realism, understanding a state's behavior and actions requires an examination of its relative capabilities and its external environment, factors that will be translated relatively smoothly into foreign policy and shape how the state advances its interests. Domestic differences between countries are thought to be relatively unimportant 
because pressures from the international system are strong enough to oblige states to behave in the same way regardless of their internal characteristics.

Hypothesis 1: A state's growing influence in its region, or a state's emergence as a regional power, is a function of its material capabilities in relation to other state actors in that regional system. The fundamental empirical prediction is thus, over the long term, the relative amount of material power resources countries possess will shape the magnitude and ambition of their foreign policies. As their relative power rises, states will seek more influence in their region and beyond, and as it falls their actions and ambitions will be scaled back accordingly. It follows that Ethiopia's growing regional influence is a function of growing material capabilities compared to other states in the Horn of Africa.

However, the ultra-parsimonious assumptions of structural realism have steadily been challenged from a number of corners that stress the influence of domestic factors on foreign policy. The first and most common group is composed of Innenpolitik theories, which are influenced by liberalism. These essentially reverse the logic of neorealism and argue that state-level or "second image" 10 factors are dominant. Different variants of this school favor specific domestic independent variables, but they all share a common assumption that foreign policy is best understood as the product of a country's internal dynamics. In other words, to understand why a particular country is behaving in a particular way, one should peer inside the black box and examine internal factors, such as ideology, national character or identity, partisan politics, or socioeconomic structure. An oft-cited example of domestic political characteristics as the source of international behavior

\footnotetext{
10 This follows from Kenneth Waltz's work (1959) which classifies first (individual), second (state) and third (system) image politics which was systematized in Theory of International Politics (1979).
} 
is the 'democratic-peace theory,' which argues that democratic states are unlikely to use violence in their relations with one another.

A variant of realism that draws attention to the influence of domestic variables on states' foreign policies other than the anarchic structure or distribution of capabilities is 'neoclassical realism'. The term 'neo classical realism' (hereafter NCR) was coined by Gideon Rose (1998) to describe an emerging body of work in the realist tradition that attempted to bring together the structural worldview of neorealism with the ability to understand changing foreign policies associated with classical realism. NCR concurs with the neorealist premise that the anarchic international system constrains the foreign policy alternatives of states. In other words, the scope and ambition of a country's foreign policy is driven primarily by its place in the international system and by its relative material power capabilities. It also accepts that the underlying 'political philosophy' behind realism of a general doubt about "the capacity of human reason to create a world of peace and harmony" (Schweller 2003:75).

However, NCR rejects structural realism's penchant for privileging systemic over 'second' and 'first-image' variables (Rose 1998; Thayer 2000). ${ }^{11}$ The impact of power capabilities on foreign policy is indirect and complex as structural pressures have to be translated through intervening variables at the domestic level. Unlike Innenpolitik theories, NCR contends that the single most important factor determining the broad patterns of a nation's foreign policy is their relative

\footnotetext{
${ }^{11}$ For overviews of neoclassical realism see Rose 1998; Taliaferro et al 2009; Brooks 1997; Wivel 2005.
} 
material power vis-a-vis the rest of the regional/international system. But "domestic processes act as transmission belts that channel, mediate and (re)direct policy outputs in response to external forces) primarily changes in relative power...Hence, states often react differently to similar systemic pressures and opportunities, and their response may be less motivated by systemic level factors than domestic ones" Schweller (2004:164). On the basis of this general argument we can develop a second hypothesis.

Hypothesis 2: In order to understand a state's rising influences in regional affairs, or its emergence as a regional power, and analyze their foreign policy - that is, the means through which their hegemonic conduct is typically exercised - focus should shift towards second image or domestic-level variables. In other words, a state that emerges as a regional power has certain domestic characteristics that enable it to do so. Ethiopia's rise as a regional power can be explained by such domestic characteristics.

According to this proposition, the surplus of material power compared to others in a region is necessary but insufficient for "regional powerhood" and must be complemented by domestic-level factors. However, such broad-brush assertion begs the question of which domestic factors are more causally significant than others and various NCR scholars have privileged different domestic variable. Some analyze state-society relations centered on the "national executive state" with the ability to define the national interest. State elites are constrained by national politics as they must bargain with domestic actors to make and implement policies (Taliaferro et al 2009; Lobell 2009; Dueck 2009) Others put the emphasis on ideational elements at the domestic level such as ideology and nationalism (Taliaferro 2009; Sterling-Folker 2009; Schweller 2009). Leaders may sometimes 
need to appeal to nationalist sentiments to mobilize the public for war or economic development (Dueck 2006). Yet others underscore the importance of individual-level variables such as the beliefs, perceptions and motivations of political leaders who influence decision-making processes and structures (Wivel 2005; Rose 1998). How leaders perceive the relative power of the state (or the relative power of others for that matter) implies that the mere quantities of physical resources may be understood differently by different state elites.

Another intervening variable emphasized by some neoclassical realists is the strength of a country's state apparatus to extract and direct resources in its relations with society. Schweller for instance attributes the tendency by some states to 'underbalance' when faced with outside threats to the state's effectiveness at resource extraction, which in turn is contingent on elite consensus, elite cohesion, social cohesion, and regime vulnerability to opposition. In a study of why "as states grow increasingly wealthy, they build large armies, entangle themselves in politics beyond their borders, and seek international influence" (Schweller 2009:3), Fareed Zakaria introduces the notion of "state strength/power" as an intervening variable between national capabilities and the behavior of officials. State power is "that portion of national power the government can extract for its purposes and reflects the ease with which central decision makers can achieve their ends" (Zakaria 1998:9).

In a similar vein, Thomas J. Christensen introduces the notion of "national political power" to highlight how success varies among states compelled to mobilize resources to respond to perceived shifts in international balance of power, 
or 'balance internally' in Waltzian parlance. He defines national political power as "the ability of state leaders to mobilize their nation's human and material resources behind security policy initiatives [which acts as] a key intervening variable between the international challenges facing the nation and the strategies adopted by the state to meet those challenges" (Christensen 1996:11 and 13). A third hypothesis can be derived based on the salience of domestic factors, and the variables outlined above in the various NCR literature.

Hypothesis 3: In a weak-state regional system, countries where institutional strength of the state arises, where heterogeneous populations reach political accommodation and political integration, viable culture and national identity are able to extend their power regionally or emerge as a regional power. Ethiopia's growing regional influence is a result of an evolution of the state. The Ethiopian state since its formation in mid-19 ${ }^{\text {th }}$ century has evolved to accommodate ethnic and social diversity which often constitute critical obstacles to the creation and management of regional order.

I contend that hypothesis 3 to be the major source of Ethiopia's regional influence - arising largely from the evolution of the Ethiopian state capable of managing ethnic diversity and preempting possibilities for external intervention. The strength of NCR thus lies in its inclusion domestic-level variables. That makes it appropriate for Africa where, as in much of the developing world, threats that originate at the domestic level are more salient than those originating from neighboring countries. Often, domestic instability within a weak state can lead to cross-border destabilization. In Africa, states do not typically directly threaten other states, and even when they do, it is through local proxies and support to insurgencies. In most instances, regimes in Africa find it difficult to consolidate their powers in the face of internal opposition, let alone project their influence regional or externally. States 
rarely have the monopoly of the use of force in their territories. Their authority rarely extends beyond the immediate environs of the capital; and hence they are continuously vulnerable to destabilizing interventions from their neighbors. In short, a measure of state control is essential and domestic challenges need to be overcome before a state can project its influence regionally.

The case of Ethiopia in the Horn of Africa demonstrates that changes in the state have been critical in the proactive regional role the current government plays. The interaction between the independent factors as identified in my preferred hypothesis and the dependent variable (Ethiopia's emergence as a regional power) to be indirect and a three-stage process. In other words, evolution of nation building processes to embrace multi-nationality and diversity has secured Ethiopia from external pressure which in turn translates into greater projection of regional influence. However, these variables interact with material capabilities, a necessary but insufficient factor, as the variable that determines the structure of polarity within a region.

\section{Methodology and Methods of Gathering Data}

Due to its attention to domestic level variables, NCR carries a distinct methodological preference for theoretically informed narratives that trace the ways different factors relate to yield particular outcomes. Significant area expertise, often requiring deep understanding of the state structure as an intervening variable, is critical for an accurate understanding of countries' foreign policy. The theory also favors 'thick description' of how different countries' political institutions 
work, strengthened by foreign language knowledge and archival research. The basic concepts of NCR "are simple and generalizable across cultures and political systems [but] the application of the approach to any given country requires a great deal of knowledge about the nation in question" (Christensen 1996:248).

The research employs a case study approach of Ethiopia in the Horn of Africa. According to Gerring, a case study is an "in-depth study of a single unit (a relatively bounded phenomenon) where the scholars aim is to elucidate features of a larger class of similar phenomena" (Gerring 2004:341). Case studies are criticized for relying on a single sample and reaching conclusions that are not generalizable or applicable to other cases. However, case studies enable us to understand the fine grains and detail specific issues or areas and help us confirm or refute hypothesis derived from specific theories. Besides, the research adds to our knowledge of regionalism and engages in theory-building exercise adding to the literature eon international relations and regionalization. A series of case studies using the comparative method has the possibility to say something generalizable. The conclusion derived from the dissertation is likely to apply best to sub-regions of weak states, as in the case of the Horn of Africa. Moreover, the subject matter lies at the intersection of the comparative politics and international relations - the nature of the state and regional power structures. It also has the potential for comparative relevance by showing how a region with weak states develops hierarchical power structures.

The research uses process tracing and historical institutionalist approaches to reveal the link between the independent and dependent variables within a 
contextualized case analysis. The Process Tracing Method tries to "identify the intervening casual process-the casual chain and casual mechanism- between an independent variable (or variables) and the outcome of the dependent variable" (George and Bennett 2005:206). Historical institutionalism is a field of comparative politics studies causal mechanism underlying institutional changes and continuities assists us understand key changes in the Ethiopian state that explain contemporary power changes (Thelen 1999; Mahoney 2000; Mahoney and Thelen 2010). Despite its weakness, the state remains central in the conduct of foreign relations and it is the institution that should be analyzed when it comes to state strength. Among the key concepts of historical institutionalism, critical junctures ${ }^{12}$ - disruptive periods of political uncertainty that give political leaders the opportunities to initiate changes (Pierson 2004) are useful to understand changes in the Ethiopian states. Critical junctures in contemporary political history of Ethiopia will be identified to make sense of changes within the state in terms of state strength and capacity. With regards to data gathering methods, the research capitalizes on qualitative information, much of which is available from secondary sources. These comprise archival research of books, journals, newspapers and internet sources.

12 Other key concepts include path dependency - referring to the inertia to initial conditions reproducing institutions over time and establishing patterns of long-term continuity - and compliance - the discretion enjoyed by political actors to make use of gaps between rules as formulated and their actual enforcement. 


\section{Significance of the Study}

This study has both theoretical and policy relevance. It will add to our understanding of regions in general and regional powers. More specifically, it shed slight on how a hierarchical regional structure emerges in a regional set up with no apparent center of power and more or less equal distribution of capabilities. However, the research challenges a static understanding of power hierarchies and demonstrates the dynamics of a regional structure should be sought at the national level. By so doing it also contributes to theories of change within the broader NCR theoretical framework with reference to the interaction of state and regional level factors.

The research could further link with studies of state history, structure and strength. Much of the literature on the nature of the state concentrates on the implications of state capacity on political developments such as democratic transition and consolidation; or the emergence duration and termination of civil conflicts. However, how state strength (as opposed to "national strength") affects foreign policy in general or regional roles in particular has not been systematically studied. My approach is fairly novel in the sense that it links the fields of IR and comparative politics and examines the effects of state capacity on external relations and regional powers status in particular.

An attendant concern with the case study methodology is whether conclusions drawn from the research are applicable to other cases. The Horn of Africa sub-region is a weak state system that has been without an apparent center of power. Therefore, the conclusions may not apply to regions with already 
established obvious power centers. However, in general terms the shift of focus to domestic factors has the potential to apply to other regions as well. For instance, it could be argued that the two oft-cited regional powerhouses in Africa - South Africa and Nigeria - had to undergo profound domestic changes to extend their regional influence - namely the end of apartheid in the case of the former and of military rule in the latter. The specific state-level variables may change from one region to the other, but their overall relevance is brought into focus. Second, even in regional arrangements with obvious power centers, the approach could help analyze the emergence of alternative and competitors. The research could also be the basis for further investigation on the implications of regional powers on regional security or economic integration. By so doing it could prove important on how to approach emerging countries, a policy question of whether to harness their increasing power in problematic regions for the sake of stability and development.

\section{Dissertation Outline}

The dissertation has seven chapters including the Introduction and Conclusion (Chapters 1 and 7). As pointed out earlier, the dependent variable in this research is the emergence of Ethiopia as a regional power, and the next logical step is to make the case for Ethiopia's rising regional presence and role in the Horn of Africa.

Chapters 2 and 3 discuss how this growing sphere of influence manifests in regional relations. Chapter two contends with the bi-lateral relations with Eritrea and Somalia. Chapter 3 investigates how Ethiopia has projected its interests, provided public goods and perceives its role as a regional power. Once the case 
has been made for the rise of Ethiopia's regional power, the following chapters evaluate the variables the hypotheses develop.

Chapter 4 presents and analyzes the evolution of the regional distribution of material capabilities to determine the extent of regional domination and tests whether Ethiopia's growing influence can be attributed to a significant surplus in terms of relative material indicators. Chapter 5 tests the preferred hypothesis - a historical institutional analysis of the Ethiopian state with the intention of identifying points of inflection that contributed to state strength. domestic Ethiopian politics heeding attention to the nature and evolution of the state in its relation to the society. Chapter 6 explores Ethiopian national identity as a factor in Ethiopia's emergence as a regional power. The final section, chapter 7, presents the significance of the study and its implication from both theoretical and policy-making angles. 


\section{Ethiopia as a Regional Power - Bilateral Relations with Somalia and Eritrea}

The question of regional and sub-regional hegemony is an old question in the field of international relations. Ethiopia's position in the Horn of Africa is one good case where this problem must be studied. As the introductory chapter stipulates, this research investigates whether Ethiopia's rise as a regional power in the region could be attributed to (a) the regional distribution of material capabilities or factors at the national or domestic levels including (b) institutional development in aspects of evolution of the Ethiopia state or (c) Ethiopia's sense of national identity and historical importance, which imbues the population and elites with a commitment to acting as a regional power. The first logical step is to demonstrate whether Ethiopia plays a dominant role in contemporary inter-state relations in the Horn of Africa - a role that can be defined as "regional powerhood". Chapters 2 and 3 aim to substantiate this argument.

This chapter presents the cases of Ethiopia's relations with countries in the region. Relations with Somalia and Eritrea will be discussed extensively and, less extensively with Kenya and Sudan. Several reasons justify the selection of this approach. First, Eritrea - both before and after its independence in 1993 - and Somalia have consistently posed the greatest challenge to Ethiopia's foreign relations despite successive regime changes in Addis. Second, the cases demonstrate Ethiopia's bi-lateral dominance, in addition to the political dynamics 
at the regional level, through alliances and interactions within regional institutions. Third, the cases also illustrate that Ethiopia's dominant role is contested by other regional countries, that regional powers do not always get their way and have to accept sub-optimum outcomes.

\section{Ethiopia's Role in Somalia}

The bulk of existing literature on regional interactions in the Horn of Africa cites Somalia as an instance of Ethiopia's regional dominance. The case of Somalia is a well-documented example of bilateral relations between a rising regional power - Ethiopia - and a former challenger - Somalia. It reveals manifestations of interests from states in the region aiming to exercise their regional influences. After Somalia's central government collapsed in 1991, Ethiopia has played a noticeably prominent role in internal Somali politics. This role has been contested from regional and extra regional states such as Eritrea and Egypt. In addition, the crisis in Somalia underlines the dynamics of multilateral cooperation and opposition among members of the relevant regional organization, the IGAD. The case also illustrates the significance of politics at the global level pertaining to the interest that the long-term social and political collapse in Somalia has attracted especially in the US-led GWOT.

With a homogenous social and economic structure including ethnic identity, language and religion, Somalia has attributes to be an ideal nation-state unlike the 
multi-national states of much of the rest of Africa. ${ }^{13}$ Prior to colonial partition, Somali-speaking people formed a well-defined geographic, cultural, and linguistic unit in the Horn of Africa with a distinct sense of identity (Lewis 1967). The partition of Somali-speaking people among different political entities, however, dates to the late $19^{\text {th }}$ century when the vast area in the Horn inhabited by ethnic Somalis was divided by three European colonial powers within the context of the "scramble for Africa." Britain took control of the northern part, what is currently Somaliland, in addition to parts in north-eastern Kenya populated by ethnic Somalis. Italy seized territories along the south-eastern coast later forming a colony consisting of present-day Somalia apart from Somaliland and France established a colony in what is at present Djibouti. Besides these distant powers, Ethiopia (then Abyssinia) also expanded into territories with a Somali majority population, currently the Somali Region of Ethiopia formerly known as the "Ogaden Province" (Woldemariam 1964; Lewis 1967, 2008).

In 1960, Italian Somaliland and British Somaliland became independent and merged to form Somalia. For Somali nationalists, independence was a critical first step in the quest for a unified Somali state that would ultimately incorporate all Somalis. Somalia's new leadership aspired for a Greater Somalia - practicing what is commonly referred to as 'irredentism' - seeking to bring all ethnic Somalis under

\footnotetext{
${ }^{13}$ Somali society is often characterized as homogenous, predominantly speaking one language (Somali), having the same culture and similar economic system (pastoralist), and following the same religion (Islam). While this is generally the case, Somalis are also divided into four major clans - Darood, Digil/Mirrifle, Dir and Hawiye - which are further divided into hundreds of sub-clans. There are other small tribes such as the Bantu, Bajun, Jiito and the Sab. The Bajun, Jiito and Baraawe have their own indigenous language which is a mix of Somali, Swahili and Arabic. (Abbink 2009; Lewis 1999; Besteman 1999).
} 
one nation-state. ${ }^{14}$ However, the irredentist designs set the new state on a collision course with its neighbors complicating Somalia's relations with Ethiopia and Kenya. The decision by the newly formed OAU in its second annual summit in Cairo in 1964 to keep colonial boundaries sacrosanct dealt a blow to Somalia's territorial aspirations (OAU 1964; Yihun 2014). Thus, "any chances of attaining her [Somalia's] objectives through pan Africanism were limited...[as] Ethiopia and Kenya were destined to exercise more influence on African affairs than Somalia" (Castagno 1964:183).

Once the lawful path for unification was stymied, Somalia increasingly resorted to belligerent means ranging from open hostility to supporting insurgencies in neighboring countries. In Kenya, the Somali government backed the Northern Frontier Districts Liberation Front (NFDLF) in its unsuccessful struggle for secession during the Shifta war that lasted from 1963 to 1967 (Whittaker 2015). Somalia engaged in two armed conflicts with Ethiopia within two decades of its existence. The first clash between Ethiopia and Somalia in 1963-64 needed the intervention and mediation of the OAU and Sudan (Castagno 1964; Woldemariam 1964).

Second and more significantly, Siad Barre's government ${ }^{15}$ revived its ambitions to incorporate the Ogaden into Somalia while Ethiopia appeared to be teetering on the brink of collapse following the 1974 revolution that overthrew

\footnotetext{
14 This nationalist project was symbolized in the national flag which features a five-pointed star each representing former British Somaliland, Italian Somalia, Djibouti, the Ogaden province of Ethiopia and the north-eastern part of Kenya.

${ }^{15}$ Siad Barre came to power in a coup d'etat in 1969 and remained in power until 1990.
} 
Emperor Haile Selassie, leading to the Ogaden War (1977-78). The war began with support for the Western Somali Liberation Front (WSLF) - a secessionist rebel movement in Ethiopia - but eventually involved a full-scale invasion of regular Somali armed forces. In the early stage, the Somali army penetrated deep inside Ethiopian territory beyond the Ogaden region Somalia claimed. Ethiopian forces eventually reversed the tide of war and drove out Somali troops from all the conquered areas with the support of the Soviet Union, Cuba and Yemen (Donna 2010; Tareke 2000).

Ethiopia's re-conquest of the Ogaden and removal of Somali forces turned out to be a serious setback for the nationalist sentiments in Somalia as internal fault lines in the Somali nation that have been kept in check reappeared. Once the dream of a 'Greater Somalia' that had sustained tenuous cross-clan alliances in the first decades after independence collapsed, armed insurgencies proliferated along clan and sub-clan ties (Lewis 1982, 1989). Two opposition groups emerged in response to the political marginalization of the northern provinces - the Somali Salvation Front $(\mathrm{SSF})^{16}$ (in 1976) in the northeastern province inhabited by the Darood/Majeerteen, and the Somali National Movement $\left(\right.$ SNM) ${ }^{17}$ (in 1981) in the northwestern provinces inhabited by the Issaq. By 1989, two more armed groups,

\footnotetext{
${ }^{16}$ Both rebel movements were supported by Ethiopia. One of the leaders of an attempted coup in 1978, Colonel Abdulahi Yusuf Ahmed, together with a group of Majerteen tribe military officers escaped to Kenya and then to Ethiopia and founded the Somali Salvation Democratic Front (SSDF). With the backing of Ethiopia, he later became the President of the Transitional Federal Government (TFG) in 2004.

${ }^{17}$ The SNM was formed in London on 6 April 1981 and secured the help the Ethiopian government (Jhazbhay 2009).
} 
the Somali Patriotic Movement (SPM) and the United Somali Congress (USC), were engaging government forces in the central regions (Vinci 2006; Gilkes 1989). These groups would ultimately overthrow Barre and weaken the Somali state. The absence of a consolidated, strong central state left Ethiopia as a clear regional hegemon.

\section{Peace Initiatives in Shattered Somalia}

The expanding war culminated in the fall of the Barre regime in January 1991 and Barre was forced into exile. However, his exile did not usher a new era of peace and stability. On the contrary, the country descended into a spiral of violence resulting in an extended period of complete state collapse and disintegration, so much so that "Somalia" became a byword for state collapse. Between 1991 and 2008 , there have been no less than eighteen attempts to bring the various warring factions together to form a national government. These efforts follow a similar pattern. First, initiatives for negotiations emanate from groups within Somalia. However, these groups often look for outsiders to facilitate the talks, paving the way for regional neighbors who seldom are neutral bystanders to use their influence to manipulate outcomes by excluding factions they believe are hostile to their interests or are backed by a regional foe. Second, most of the peace negotiations are not inclusive of all factions and thus are susceptible to the veto power of spoilers. ${ }^{18}$ Third, initiatives are often followed by counter-initiatives under

\footnotetext{
18 Some successful localized peace conferences have been held such as in Burao (1991), which led to the formation of a separate administration in Somaliland; Borama (1993), which consolidated Somaliland's success as a separate administration; and Garowe (1998), which established the
} 
the tutelage of another regional country and involving groups excluded from the earlier process. Therefore, most of the peace conferences were directed against and manipulated by one faction leader or another, and constant meddling by external powers.

The UN organized a mission to Somalia (UNOSOM I) in 1991, followed by a follow-on mission in 1993 (UNSOM II). After the departure of UN peacekeeping forces under United Nations Operations in Somalia (UNOSOMII) in 1995 and considering the failure of international actors to pacify Somalia, the newly reorganized IGAD took over the mantle of coordinating the peace initiatives. Ethiopia was given the mandate to mediate Somali opposition forces by IGAD and the OAU. Thus, in November 1996 Ethiopia sponsored a national conference in the Ethiopian town of Sodere in which a diverse group of Somali faction leaders attempted to form interim national institutions by forging a ruling coalition - the National Salvation Council (NSC) - in opposition to the self-proclaimed government of the Somali National Alliance (SNA) led by Hussein Aidid. The conference proceedings, however, were boycotted and neither SNA (dominant in Mogadishu) nor SNM (ruling Somaliland) recognized the legitimacy of Ethiopia's initiative (Mukhtar 2003).

Although the Sodere conference failed to bear fruit in terms of moving Somalia towards national reconciliation, it had two long-term implications for subsequent peace negotiations. First, the meeting encouraged decentralization of

\footnotetext{
Puntland administration. But overall, other peace initiatives have not met the objective of attaining stable governance at the national level (Walls 2009; Crisis Group 2006).
} 
authority to the local administrations and encouraged the formation of regional authorities oriented towards establishing a federal state. A case in point is the consolidation of the Puntland autonomous administration in 1998 under the aegis of SSDF that followed the Sodere conference. Second, the conference adopted the ' 4.5 formula', a fixed proportional quota for regulating clan representation as proposed by Ethiopia, allocating an equal number of seats to each of the four major clans and half of the total number of seats to minorities.

\section{Map 2. Somalia}

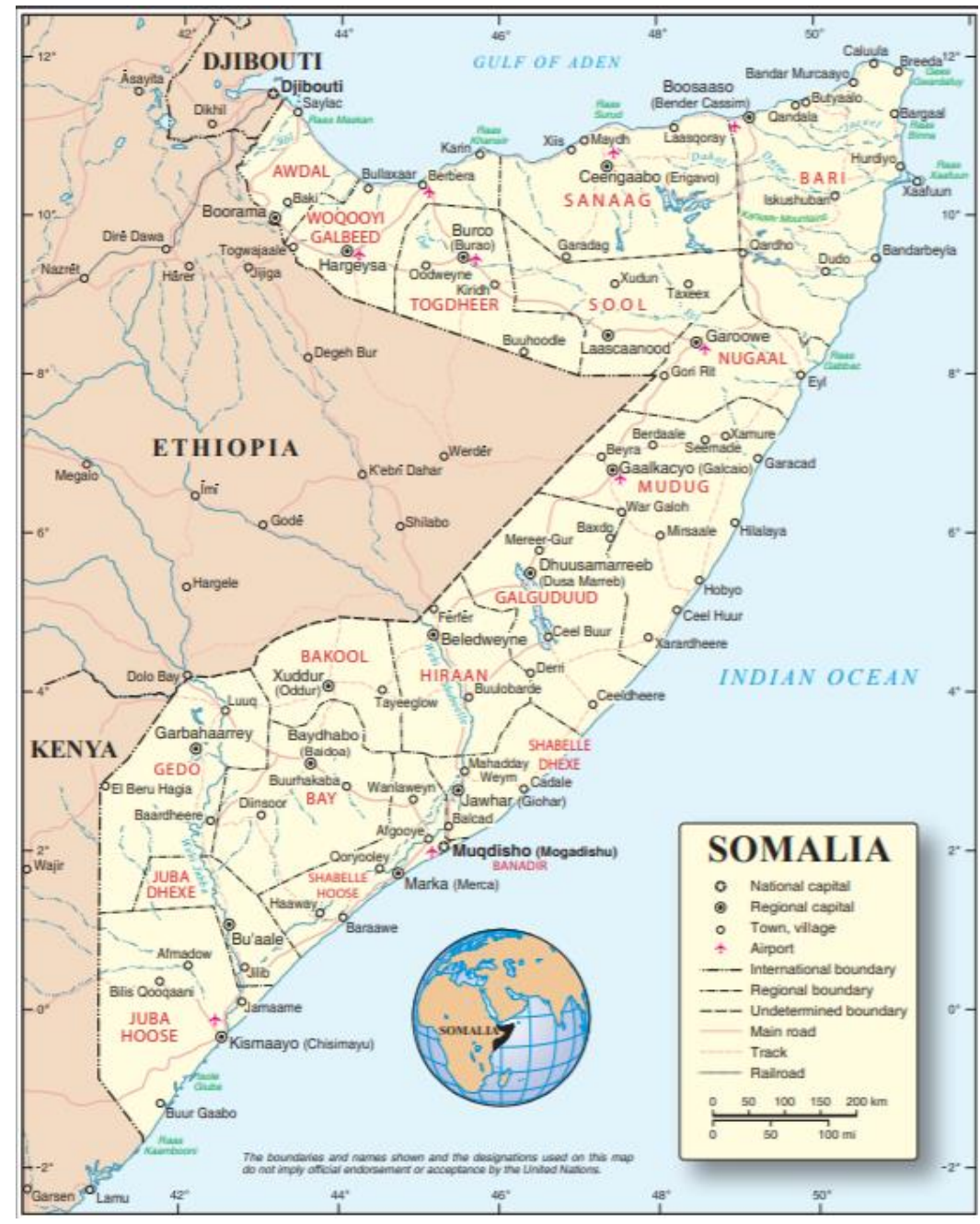

Source: United Nations (2011) 
The adoption at the Sodere peace conference of a clan-based power sharing formula proposed by Ethiopia demonstrated the level of influence Ethiopia enjoyed. In 1995, Ethiopia had adopted an ethnic based federal system and the 'export' of a similar formula to Somalia was seen as an extension of Ethiopia's regional influence and, as will be discussed in the next chapter, an attempt by Ethiopia to keep Somalia divided and weak. Before the Sodere accords, the 4.5 quota formula Ethiopia proposed for the representation of clans could be implemented, Egypt invited many of the same groups to its capital in what came to be known as the Cairo Process (March 1997) in a thinly veiled attempt to counterbalance growing Ethiopian influence in Somalia. Representatives of several Somali factions met under the auspices of Egypt and the Arab League ostensibly to reconcile Hussein Aideed's SNM and the NSC that had been formed during the negotiations held in Sodere.

The negotiation in Cairo was also attended by another major group in Mogadishu, the Somali Salvation Alliance (SSA), led by Ali Mahdi Mohammed. The negotiations partially succeeded in trying to organize a national meeting inside Somalia and in forming the Benadir regional authority in southern Somalia. The Ethiopian-backed NSC leaders, however, refused to participate in the conference or acknowledge its outcomes. This meant that although both the Sodere and Cairo conferences generated tentative transitional national charters, they failed to produce institutions capable of implementing them and ended up highlighting the divisions among Somali armed faction leaders, and among interested regional powers. 
The Ethiopian and Egyptian sponsored conferences at Sodere and Cairo respectively highlighted divisions among Somali faction leaders and involved regional powers. In 1998, a new strategy of rebuilding the Somali state surfaced. Commonly referred to as the "building blocks" approach, the inspiration originated in a position paper drafted by the Ethiopian Ministry of Foreign Affairs and was reluctantly accepted by members of IGAD and other stakeholders including Italy, Egypt, and the UN (Bryden 1999). The proposal recognized that Somalia was far from a state in complete anarchy as portrayed in the international media, and it called for an alternative course of action by supporting existing authorities in areas with basic systems of administration and order.

By the time this idea was floated, regional administrations had already developed in Somaliland (a separatist state in the northwest) and Puntland (a nonseparatist, autonomous state in the northeast), the Rahanweyn Resistance Army's (RRA) administration of Bay and Bakool regions, and the Benadir Regional Authority (see map 2). The "building-block" approach aimed to pull these nascent states together through a federative approach of political reconstruction (Irin 1999). Some parties, notably Egypt, questioned the plan, fearing it favored Ethiopia's allies in Somalia and the federalist plans would render any subsequent central government unable to exercise real authority. However, the approach secured the endorsement of IGAD and much of the Western donor community and provided a platform for temporary political reconciliation in Somalia (Menkhaus 2006; Doornbos 2002). 


\section{The Arta Peace Process and the TNG}

The "building blocks" approach came to a premature end when Djibouti's President Ismail Omar Guelleh launched a new initiative in September 1999. Lifted by its strategic importance during the Eritrean-Ethiopia war of 1998-2000, Djibouti took advantage of the distraction to look for a more assertive stance in search of a more autonomous role for itself in the politics of the Horn (Doornobs 2002). The initiative for the new process was taken by a group calling itself the SPA ${ }^{19}$ composed of representatives of warring factions and civil society groups in Somalia. The peace conference began in May 2000 in Arta, just outside the Djibouti capital, and ended with the endorsement of a Transitional National Charter (TNC), and the formation of a Transitional National Government (TNG) and a Transitional National Assembly (TNA in August 2000. On August 13, 2000 the TNA met for the first time and elected Abdalla Deerow Issaq as Speaker, Abdikassim Salad Hassan as President and Ali Khalif Galaydh as Prime Minister.

At the time of its conclusion in July 2000 , the Arta peace process was hailed as unprecedented. Unlike previous conferences, representation was more comprehensive, and a diverse group of armed groups took part in the negotiations except, notably, Somaliland. Moreover, whereas peace processes in the past were dominated by the armed factions, Arta offered a broader role for civil society groups. A wide array of clan and traditional elders, women, scholars and

\footnotetext{
19 The SPA initially included Puntland's Yusuf and the RRA. Both were closely allied with Ethiopia and left the Arta peace process around the conclusion of the conference apparently at the behest of the Ethiopian government (Elmi and Barisse 2006, New York Times 2000).
} 
representatives of Somali civil society organizations took part. ${ }^{20}$ The peace process also laid the foundation for restoring national institutions of governance. A transitional charter was promulgated to provide the edifice of governance for a three-year period, after which elections for a permanent government were to be held. The charter defined a political arrangement to consolidate the areas where peace had been restored and provided for eighteen regions based on the administrative borders that existed at the fall of the Barre regime in 1991.

The conference also differed from previous attempts in the international attention and support it received. From its inception the process was backed by Djibouti, Egypt, Libya, the Arab League, IGAD ${ }^{21}$ and the $U N^{22}$. The swearing in of the new president was attended by the leaders of Djibouti, Eritrea, Sudan, Yemen, and Ethiopia, and diplomats and officials from several African, European and Arab countries. Senior representatives of the UN, the OAU, the Arab League and IGAD were also present. The TNG embarked on a campaign to consolidate its position internationally by taking up Somalia's vacant seats in the UN, the Arab League, Organization of Islamic Council (OIC) and IGAD. Lacking the ability to open or control the sea and airports of Mogadishu, the TNG was compelled to turn to

\footnotetext{
${ }^{20}$ Out of a total of 810 delegates to the peace conference about ninety were women. Twenty-five seats in the 225-seat Transitional National Assembly (TNA) were allocated for women, and twentyfour seats for minority clans.

${ }^{21}$ IGAD endorsed Djibouti's proposal through its Standing Committee on Somalia in its $7^{\text {th }}$ annual summit in Djibouti. (IGAD 1999)

22 In his annual report on Somalia, the UN Secretary General Kofi Annan praised the peace process as a welcome development for the wide international recognition and asked the UN security council for consolidating its gains. (United Nations 2000)
} 
outsiders for financial assistance. This was forthcoming from Libya and other members of the Arab League. ${ }^{23}$

Despite this, the Arta process and its product, the TNG, did not fare better than previous accords when it came to the goal of national reconciliation or restoring the central government. Internally, securing the compliance of various armed factions proved complicated and the TNG was stymied from the outset by divisions and defections. Several clans and sub clans highlighted the dominance of Mogadishu-based clans, especially the Hawiye/HaberGedir/Ayr sub-clan, and the TNG fell short of living up to its role as government of national unity. Somaliland continued in its refusal to join the negotiations or the transitional administration. Despite initial overtures, Puntland's president Abdillahi Yusuf rejected the outcomes claiming irregularities in the selection of the delegates. He was joined by another major warlord, Hussein Aideed (BBC 2000). This was followed by several armed groups in Mogadishu who vowed not to recognize the new government and accused its leadership of driving the country back to the brink of war. The territorial reaches of the new government thus remained tenuous despite broad international recognition and support and the TNG failed to assert its authority beyond limited pockets of the capital. In fact, in 2002, Mogadishu suffered its heaviest violence that rendered south-central Somalia more insecure and inaccessible than at any time since the early 1990s (Menkahus 2003).

\footnotetext{
${ }^{23}$ This was immediately recognized by the TNG leadership, which went so far as to call for an 'Arab Marshall Plan' for Somalia.
} 
Externally, the formation of the TNG accentuated the deep divisions of the regional players in a pattern reminiscent of earlier initiatives and it set back Ethiopia's design in Somalia. The enthusiasm with which Egypt and other Arab states greeted the new administration and extended diplomatic and financial support meant that Ethiopia viewed the TNG as a bastion of anti-Ethiopian alignment in the Horn (Menkhaus 2003). Ethiopia accused the TNG and its leadership of links to Somali Islamist groups, including the extremist al-Itihaad alIslamia. Some leading TNG figures were associated with al-Itihaad and the less radical Islamist movement, Harakaat al-Islam. As a result, Ethiopian-backed militias opposed to the TNG in 2001 formed a loose alliance of factions called the Somalia Reconciliation and Restoration Council (SRRC) (Irin 2001; Rosenthal 2001). Abdullahi Yusuf, a close Ethiopian ally and president of the autonomous state of Puntland in north-east Somalia, became the alliance's leader.

By the beginning of the $21^{\text {st }}$ century, the rift between the SRRC and the 'Mogadishu Group', of which the TNG was an integral part, defined and polarized the political dynamics in Southern Somalia. The SRRC was "backed by Ethiopia, fiercely anti-Islamist, dominated by some lineages of the Darood clan-family, based mainly in regions outside Mogadishu and federalist", and the Mogadishubased coalition including the TNG enjoyed "support from the Arab world and is staunchly anti-Ethiopian, includes Islamists in its alliance, [and was] dominated by certain lineages from the Hawiye" (Menkhaus 2007; see also Elliot \& Holzer 2009). According to the International Crisis Group "Ethiopia remained the driving force behind the SRRC, providing military material and expertise, albeit on a much 
smaller scale than what Arab states gave the TNG and its militia allies. Neither group achieved a decisive military or political advantage...By November 2002, as

the TNG moved well into the final year of the three-year term that was provided by the Arta Conference, there was little to distinguish it qualitatively from the other Somali factions" (Crisis Group 2006).

\section{The Eldoret/Mbaghati Peace Conferences and the TFG}

For much of its brief existence, the TNG remained largely ineffectual due to the weakness of its leadership coupled with Ethiopia's hostility to the TNG. In light of its failure to restore functional government and with the imminent end of its threeyear mandate, an IGAD summit in Khartoum in January 2002 called for yet another peace initiative to reconcile the TNG with its rivals in the Ethiopian backed SRRC (IGAD 2002). The "Eldoret process", named after a resort city in Kenya, where the talks were held, commenced in October 2002 with a gathering of Somali political leaders. A Technical Committee comprising IGAD frontline states (Djibouti, Ethiopia, Kenya) was assigned to manage the negotiation process (Irin 2002). Given Djibouti's and Ethiopia's partisan support for TNG and SRRC, respectively, Kenya was entrusted with the chairmanship of the committee to provide unbiased and neutral leadership.

In the months leading to the 2002 conference, regional differences were once again clearly drawn. Ethiopia stood behind the SRRC and expected a new, more friendly, transitional authority to come out of the negotiations. Djibouti, Eritrea, and Egypt strongly supported the TNG. It soon became clear that the 
Eldoret process was manipulated by Ethiopia, often with the consent of Kenya, which shared Ethiopia's apprehension of an Islamic state in neighboring Somalia, towards the creation of an SRRC-dominated government as Djibouti struggled to defend the interests of the TNG (Irin 2003). ${ }^{24}$ Divergent interests among the three member countries of the technical committee undermined its functions.

In addition to the dysfunction of the technical committee, several other roadblocks emerged. First, differences arose on whether to allocate seats along clan or faction lines. The formula for factional representation proposed 262 seats to be distributed between sixteen factions, with 100 additional seats reserved for "civil society". Second, the delegates differed on whether to adopt a federal or unitary form of government (Crisis Group 2004). After a protracted and often contentious process, in November 2002, the delegates approved a draft transitional charter that would transform Somalia into a federal state. The charter outlined the Transitional Federal Institutions (TFIs), the most important ones being the Transitional Federal Parliament (TFP) and the Transitional Federal Government (TFG). The TFG was formed in late 2004 and early 2005 at the end of the two years of negotiations in Kenya. The path seemed clear to replace the TNG with an interim federal government that most observers felt was dominated by the SRRC, and, indirectly, Ethiopia. The newly formed TFP elected the pro-

\footnotetext{
${ }^{24}$ Djibouti briefly suspended its role in the technical committee stating the peace process has lost its objectives. The President of Djibouti Ismail Omal Gelleh said "Djibouti and Ethiopia have very different points of view... and Our temperaments are very different, and we react differently to problems. But the major issue is "with Kenya who thinks Djibouti is just a small country and that Ethiopia represents its interests. So, it gave more importance to Ethiopia and ignored our point of view" (Irin 2003).
} 
Ethiopian Abdullahi Yusuf as the President of the new federal government (Samatar 2007). Thus, both the allocation of delegates to the negotiation and members of the new government, and accepted form of administration favored the Ethiopian-backed SRRC and its allies. According to Menkhaus (2007:365) the

82-person cabinet which [Prime Minister] Ghedi formed was nominally a reflection of the 4.5 formula, but in reality concentrated power over key government positions in the hands of the President's clan, and more generally in the hands of the Ethiopian-backed SRRC alliance. The leadership and sub-clans most closely identified with the old TNG were conspicuously marginalized in the new government. What was intended to be a government of national unity was, yet again, a government based on one of the country's two main coalitions at the expense of its rival.

Ethiopia's succeeded in its plan to have Yusuf as President and to reorganize Somalia along a federal system of administration. With regards to the formation of a stable government on the ground in Somalia however, the TFG ran into serious hurdles from the outset. First, disagreements arose on relocating the seat of government to Mogadishu. Factions opposed to Ethiopia's prominent role in the negotiations - namely the TNG and Mogadishu-based faction leaders - struck a deal to set aside their differences and join forces in restoring security to the capital. Following this, several members of the TFG and almost half of the Members of Parliament including the Speaker moved to the capital and insisted the government do likewise since a modicum of stability had by then been established. However, Yusuf was understandably wary of moving to a location far from his power base in Puntland and where security forces were dominated by his archrivals. Therefore, the new government refused to relocate to the Somali capital and remained in 
Nairobi until the Kenyan Government pressed it to move to the Somali town of Jowhar, ninety kilometers north of Mogadishu. The dispute was finally settled in 2004 when the President and the Speaker finally agreed to move the Federal Government to Baidoa (Samatar 2007; Elliot \& Holzer 2009).

Secondly, the TFG President unveiled a proposal to invite foreign troops in a move to establish control on the ground. Previous attempts to reestablish authority had failed mainly due to the state's inability to establish the monopoly of the use of force. Cognizant of these failures, Abdulahi Yusuf soon after his election appealed to the UN and the AU for the deployment of a 20,000 -strong multinational peacekeeping force to safeguard the government and disarm the opposition (Irin 2004). The Mogadishu-based groups, including the rising Union of Islamic Courts (UIC), vehemently opposed the deployment of foreign forces in general, and particularly of Ethiopian (and Kenyan) troops as part of peacekeepers (BBC 2005). IGAD eventually agreed to send peacekeepers and decided that none of the frontline states would be part of the peacekeepers ${ }^{25}$, effectively leaving only Sudan, Uganda and Eritrea (Murithi 2009).

Neither the relocation of the federal government to Baidoa nor IGAD's decision to deploy peacekeepers, however, did little to resolve the differences between the TFG and the Mogadishu-based factions. Divisions continued to fester and by the end of 2005 a three-way contest for power took shape as rival power

25 UN Security Council resolution 1725 to lift UN arms sanctions on Somalia and allow for the deployment of an IGAD-led peacekeeping force endorsed "the specification in the IGAD Deployment Plan that those States that border Somalia would not deploy troops to Somalia". (United Nations 2006) 
centers contended for the control of southern Somalia - the TFG led by Yusuf, confined to Baidoa and sustained by the Ethiopian military; the Mogadishu Group, an array of warlords many of whom were either members of the TFG cabinet or of the parliament and composed of the opposition ministers and their local allies; and the UIC, led by Hassan Dahir Aweys and its chairman, Sheikh Sharif Sheikh Ahmed, the rapid rise of which paved the way for Ethiopia's military intervention in 2006 (Crisis Group 2006).

\section{Ethiopian Military Interventions in Somalia}

The UIC gradually took control of Mogadishu and large portions of southern Somalia. In response Ethiopian troops crossed into Somalia in December 2006 to free the capital city Mogadishu from the UIC and install the TFG. This, however, was not the first time Ethiopian troops crossed into Somali territory. Initial military incursions into Somalia in 1996 and 1998 after the collapse of the Somali state had targeted the Islamist group Al-Itihaad al-Islamia. Al-Itihaad was a Somali fundamentalist movement that sought to establish an Islamic state in Somalia by uniting all Somali-inhabited territories in the Horn of Africa including the Ogaden in Ethiopia (Tadesse 2002). It took advantage the Somalian power vacuum and took control of the Gedo region in 1991. The small town of Luuq in southwestern Somalia, close to the border with Ethiopia, became the seat of its administration where Islamic courts, Islamic education institutions, a police force, and health and welfare centers were established. However, Al-Itihaad's efforts to expand into the Northern regions of Somalia in the first half of the 1990s had been thwarted by the 
SNF and SSDF (in Somaliland and Puntland, respectively) with the support of Ethiopia (Le Sage 2001).

The group maintained its presence and control over parts of southern Somalia until the 1996 to 1999 period when Ethiopia launched major military operations in Somalia (Loewenstein 2010). These interventions followed terrorist attacks inside Ethiopia in 1996 orchestrated allegedly by Al-Itihaad, including an assassination attempt on the Ethiopian Minister of Transport and Communications (an ethnic Somali) on July 8 and the bombing of Wabe-Shebelle Hotel in Addis Ababa on August 4. Ethiopia responded with a cross-border military operation to the Gedo region in Somalia and destroyed Al-Itihaad's main military bases in the towns of Luuq and Buulo Hawwa near the Ethiopian border (Tadesse 2002).

The Eritrean-Ethiopian war of $1998-2000$ added a new dimension to the conflict as Somalia turned into a site of proxy warfare between the two belligerent states. In 1998 and 1999 Ethiopia conducted a series of military incursions into Somalia against an Eritrean backed coalition of forces composed of Al-Itihaad, Aideed's SNA, and Ogaden National Liberation Front (ONLF) and Oromo Liberation Fronts (OLF) fighters opposed to the Ethiopian regime, and using Somalia as an operational base to launch attacks. The Ethiopian military, with the help of the RRA, attacked and dislodged opposition bases in various parts of southern Somalia. The operation ended in 1999 after Hussein Aideed was forced to renounce his support for Eritrea and agreed to disarm Islamist forces including Al Ittihad and Ethiopian rebel fighters in Somalia (Africa Intelligence 1999). 
In the wake of the military defeat at the hands of Ethiopian forces, Al-Itihaad resorted to working within the Somali clan system to build a powerful network of support with various clans and businesses that had ties with various Islamic courts. It turned its activities away from military endeavors toward the provision of welfare and control of remittances ${ }^{26}$ (Le Sage 2001). Soon, it expanded its control to the local sharia courts including in Mogadishu mainly around the courts' stronghold in seaport town of Merka and the Bakara Market. Al Ittihad formed sharia courts spurred by large scale business. Ahmed Dahir Aweys ${ }^{27}$, a self-professed military commander of Al-Ittihad, became the Secretary General of the Joint Islamic Courts (lbid.).

By the time Al-Itihaad's influence within the local Sharia courts expanded, the courts in Somalia had been in existence for close to a decade. Following the collapse of central authority, the internal fragmentation of this ethnically and religiously homogenous nation followed clan and sub-clan lines. Political Islam emerged as a reaction to political collapse and social fragmentation, and as an alternative to Somali nationalism, which could no longer serve as a viable ideology

\footnotetext{
${ }^{26}$ Somalia is heavily dependent on remittances, which total between $\$ 500$ million to $\$ 1.5$ billion annually. Remittances have been essential for the impressive growth in money transfer and telecommunication businesses, commercial imports of consumer goods, the transportation sector, real estate investment and housing construction, and a range of service industries (Menkhaus 2006/2007).

${ }^{27}$ Aweys is a former Somali military officer who fought in the Ogaden War and was sentenced to death by the Barre regime for membership in al-Ittihaad. In 1992, he became al-Ittihaad's vice chairman and military commander and played a key role in its attempt to take control of the north east from the SSDF and its leader Abdillahi Yusuf. Aweys's forces were routed with hundreds killed. Aweys's involvement with AIAI earned him not only Yusuf's enduring hostility, but also that of Ethiopia and the U.S. The latter believes he was involved in the 1998 embassy bombings. Addis Ababa also holds Aweys responsible for terrorist attacks in the mid-1990s, including the bombing of two hotels and the attempted assassination of a cabinet minister (Crisis Group 2006:17).
} 
to hold the country together. Local sharia courts spread as part of a range of locallevel administrative structures that supplied effective day-to-day governance. These courts were widely welcomed by local communities owing to their ability to produce a modicum of stability in the midst of political uncertainty. The sharia court militias, regarded to be more disciplined and principled than the followers of the warlords, became a means of upholding of law and order at the expense of the unpopular warlords (Ahmad 2009; Crisis Group 2005; Barnes and Hassan 2007; Menkhaus 2006).

During their formative years, the Islamic courts by and large remained under the control of moderate and traditional segments of Somali society that followed Sufism - a moderate brand of Islam. However, many later became catalysts for a new, radical Islamist movement. In 2000, a growing network of sharia courts in Mogadishu and the countryside fell under the control of hard-liner Islamists including al-Itihaad, forming the Joint Islamic Courts Council (JICC) and Aweys became the de facto leader of the Courts in Mogadishu (Crisis Group 2006; Le Sage 2001; Menkhaus, 2002 and 2003). In 2004, the moderate Sheikh Shariff became Chairman of the Courts' Executive Council, and Aweys became Chairman of the powerful Consultative Council - the Court's Shura. Although not all of the leadership of the UIC (which eventually assumed the name of the Somali Supreme Council of Islamic Courts - SSCIC) subscribe to the strict Wahhabist views of Aweys and the hard-liners, the moderates within the group were unable to exert a decisive influence over the hard-liners (Barnes and Hassan 2007). 
The rapid rise of radical Islamists triggered growing anxiety in Ethiopia and in the US. ${ }^{28}$ The US initially sponsored an alliance among a group of Mogadishu warlords - the Alliance for the Restoration of Peace and Counter Terrorism (ARPCT) - as a countering force against the UIC. Small scale clashes between the ARPCT and UIC started in the beginning of 2006. By June, the UIC took decisive action against the ARPCT and mobilized its al-Shabaab militia in a battle for the control of Mogadishu. After some of the heaviest fighting in Mogadishu since 1991, the UIC militias routed the US-funded warlords and took control of the city. Within a few weeks, the Union consolidated their control over the capital, dismantled militia checkpoints that the warlords had used as extortion posts and brought a measure of stability Mogadishu had not seen since the collapse of the state. They expanded their jurisdiction to many other regions in south-central Somalia and even managed to repair and reopen Mogadishu Seaport and Airport that had been closed since 1991 (Barnes and Hassan 2007; Ahmad 2009).

However, political and security gains brought by the success of the Islamists tell only part of the story. The UIC took vigorous steps to restrict independent

\footnotetext{
${ }^{28}$ The USA was drawn directly into in the regional politics after the withdrawal of its troops in the mid 1990's. America's concern emanated from a confluence of three factors. First, in the aftermath of 9-11 and the GWoT, a Taliban-like government in Somalia so close to the strategic Red Sea and to the Middle East was a cause for alarm. Even if such a regime would not transpire, the US was increasingly apprehensive of ungoverned spaces that could be used as safe havens by global jihadist movements. The formation of the CTJF-HoA in Djibouti in 2004 indicated these fears. Secondly, and more specifically, the US accused Islamists in Somalia of sheltering individuals accused of masterminding the bombing of US Embassies in Nairobi and Dar es Salaam in 1998, and terrorist attacks on a Jewish resort in Kenya and an Israeli Jet at Nairobi international airport in 2002. Third, the US was troubled by the UIC's associations with groups classified as terrorist organizations by the US state department, including al Qaeda and al Ittihad. Moreover, the presence of senior members of al Ittihad among the ranks of the UIC, and of foreign fighters in the al-Shabaab militia indicated the globalization of the Somali conflict.
} 
social, political and civil society organizations. In the areas they brought under their control, the Islamists outlawed many of the structures of local governance and substituted customary laws with rigid applications of the Sharia. Alternative sources of authority including traditional elders, civic leaders, and parts of the business community who had fended for their own security were marginalized. Hard-liners in the UIC imposed draconian rules against what they perceived to be decadent, Western influences in the daily lives of the people, antagonizing Mogadishu residents who otherwise were thankful for the order the UIC brought (Menkhaus 2006).

For Ethiopia, Mogadishu's stabilization under the UIC was a worst-case scenario. Having a radical Islamist regime straddling the restive region of Ogaden posed serious security threats. Ethiopia regarded the UIC as infiltrated by alItihaad, and a potential entry point to the region for global jihadist movements such as al-Qaeda. Moreover, the UIC took a series of ill-considered steps to provoke Ethiopia including acceptance of arms and advisers from Ethiopia's main rival Eritrea; ${ }^{29}$ declaring jihad against Ethiopia as a reaction to the presence of Ethiopian troops inside Somali territory; support for armed Ethiopia insurgencies the OLF and ONLF; and reviving the age-old irredentist claims on Somali-inhabited portions of Ethiopia (Menkahus 2006/2007; Samatar 2007; Aawsat 2006).

\footnotetext{
29 The UN Monitoring Group's reported that "Eritrea delivered at least ten arms shipments to the UIC between May 2005 to May 2006" (cited in Crisis Group 2006:20). Moreover, the UN stated that Eritrea had deployed 2,000 troops in support of the UIC (Ibid).
} 
As a result, Ethiopia's parliament designated the Courts as a 'clear and present danger' and authorized the Government to use all necessary measures including military force to defend the TFG and Ethiopia's sovereignty (Sudan Tribune). In December 2005, the UIC militia closed in on Baidoa - the seat of the TFG - leading to small-scale skirmishes with TFG and Ethiopian forces, already present in much of the region to defend the TFG. Last ditch attempts by Sudan to mediate the UIC and TFG bore no fruit. As a diplomatic victory to Ethiopia, the UNSC passed resolution 1725 to lift UN arms sanctions on Somalia and gave the green light for an IGAD-led peacekeeping force to strengthen the TFG (United Nations 2006). Within two weeks, Ethiopia invaded Somalia with an estimated force of between 8,000 and 12,000 well-equipped troops with artillery and air support (Crisis Group 2007). In less than two weeks for the Ethiopian forces chased the UIC militias out of Mogadishu and installed the internationally recognized TFG in Mogadishu.

Despite the military victory that successfully averted the immediate threat the UIC posed, Ethiopia's intervention was criticized by many as counterproductive. Ethiopia initially stated it would not engage in a state-building exercise, and its troops would depart Somalia in a matter of weeks (Hull and Abdul 2007). It soon became clear, however, that the TFG was not in a position to fend for itself and required the extended presence of Ethiopian troops. By April 2007, only 1,200 of the 8,000 peacekeepers the AU decided to deploy had arrived in Mogadishu. Therefore, despite pledges to leave within few weeks after the war, 
Ethiopian forces were bogged down in a violent insurgency for over two years, which caused significant civilian deaths and displacement.

Ethiopia's 2006 military incursion unintentionally led to four major security challenges. First, the very presence of the troops of the "historical enemy" of Somalia patrolling the streets of Mogadishu provided a lightning rod for nationalist attacks and mobilization. Ethiopian forces faced a brutal insurgency with rebels who controlled large swaths of the capital and joined the regrouped UIC fighters. The Ethiopian soldiers lacked the ability to maintain extended presence especially in an urban setting. Any provocation by the insurgents was met by an indiscriminate shelling of densely populated residential areas and markets leading to massive civilian casualties. Ethiopian forces inflicted heavy losses on the insurgents; but the protracted insurgency was costly both financially and politically (Moller 2009; Menkhaus 2007). Human Rights Watch issued a report alleging fighters on both sides including Ethiopian troops had committed war crimes (Human Rights Watch 2008). In addition, the UN designated Somalia the worst humanitarian crisis - even worse than Darfur (Reuters). Ethiopia even had its 'Black Hawk down' moment when an its helicopter was shot down and the bodies of Ethiopian soldiers were dragged on the streets of Mogadishu (Ingris 2014).

Second, Ethiopia's intervention became a catalyst for an intense and more radical insurgency by Harakat al-Shabaab al-Mujahidin (known commonly as alShabaab or youth in Arabic) that had so far served as the military wing of the UIC, but now emerged as a separate and more radicalized group (Mosley 2015). Between 2007 and 2009, al-Shabaab successfully exploited widespread anger 
and nationalist indignation against Ethiopia's presence to boost its numbers and drum up support and funds from the Somali diaspora (Bryden 2013). By the time Ethiopian troops departed in 2009, al-Shabaab controlled most of the South and central regions, leaving the TFG and African Union Mission in Somalia (AMISOM) troops in control of less than 20 percent of territory of southern Somalia.

Third, domestically, Ethiopia's intervention contributed to an escalation of the hitherto low-key insurgency in the Somali region of Ethiopia. ${ }^{30}$ The ONLF vowed retaliation against the government in Addis Ababa for its offensive in Somalia and carried out a major attack on a Chinese oil exploration site at Abole in Ogaden in April 2007 claiming the lives of 74 civilians including nine Chinese workers. The attack raised fears that the insurgency in Mogadishu could become a wider war in the region (Menkahus 2007). The Ethiopian military embarked on a brutal, scorched earth strategy of violence, collective punishment, restrictions on food aid and forcing civilians into protected villages. Both the intensified attacks from the rebels and reprisal missions by the Ethiopian military displaced much of the population of the Somali inhabited region. By mid-2007, a major humanitarian emergency had developed. The counterinsurgency campaign brought the insurgency under control, but not before attracting intense international scrutiny of

\footnotetext{
30 The Ogaden has historically been a hard to govern peripheral region where control from Addis Ababa has been sporadic, and links between the Somalis in Ethiopia and related clans across the border in Somalia have shaped politics. The ONLF a Somali-Ethiopian insurgency that existed since 1984 was part of Ethiopia's initial transitional government in 1991 but advocated secession (allowed in the Ethiopian federal constitution) and was soon driven out of the legal political arena and displaced by rival Somali parties with closer links to the EPRDF.
} 
the human rights record of the Ethiopian regime (Human Rights Watch 2008; Lyons 2009).

Fourth, in terms of Somali politics, Ethiopia's intervention did not lead to national reconciliation and consolidation of power. The TFG could not assert its political, military, and administrative authority. The UIC was divided into its leaders who managed to escape to Kenya and Eritrea before Ethiopian forces reached the capital and the highly radicalized al-Shabaab that pursued military actions against Ethiopia. The former group, joined by disaffected members of the TFG (such as Hussein Aideed who initially was Interior Minister in the TFG), gathered in Asmara and formed the Alliance for the Restoration of Somalia (ARS) under the leadership of Aweys and Ahmad.

However, the ARS further split when in June 2008 the UN and Djibouti brokered a reconciliation conference between TFG and ARS. The conference ended with an agreement on the withdrawal of Ethiopian troops in exchange for the cessation of hostilities. The agreement also established a new parliament, expanded to 550 seats to accommodate ARS members (United Nations nd). Sheikh Sharif Ahmed Yusuf, the moderate former chairman of the UIC replaced Ethiopia's favorite Abdulahi Yusuf, who was forced to resign under pressure from IGAD, the AU-PSC and UNSC for his failure to work with the Prime Minister and becoming an obstacle for the Somali peace process (Kasaija 2011:25). Aweys opposed the rapprochement with the TFG and remained in Asmara until he returned to Mogadishu in 2009. And the militant wing of the UIC, Al-Shabaab, rejected any compromise with the TFG until Ethiopian troops were out of the 
country. Thus, by the time Ethiopia's troops withdrew in 2009 the hardliner and moderate wings of the UIC were either in power in the capital or fighting a bloody civil war against Ethiopia, the TFG and AMISOM forces. From an Ethiopian point of view, that was the sub-optimal outcome in terms of political settlement.

\section{Ethiopia's Relations with Eritrea: Military Defeat and Containment}

Beside Somalia, the most consistent test to Ethiopia's security, and aspiration to elevate its status to regional leader, has come from Eritrea. The Eritrean war of secession - at the time the northernmost province of Ethiopia - that started in 1960 and dragged on for almost 30 years claimed the lives of large number of people and drained the resources of the Ethiopian state. Even after independence, the high degree of militarization of the Eritrean regime and its constant meddling in regional affairs posed security challenges to Ethiopia. This sub-chapter deals with recent developments in the relations between Eritrea and Ethiopia with the view of supporting the argument that the military defeat of Eritrea in 2000 and subsequent containment of the challenges from Eritrea sheds light on Ethiopia's regional role and influence.

The two liberation movements, Eritrean People's Liberation Front (EPLF) and the Tigrean People's Liberation Front (TPLF) - the core group forming the EPRDF - worked closely during the armed struggle against the Ethiopian military regime. Relations between the two liberation movements had occasionally been tense and differences had surfaced on ideology, military strategy and administrative system before and after they came to power (Plaut 2001; Gilkes and 
Plaut 1999; Tekeste and Tronvoll 2000; 1996 and 1997; Reid 2001).1991 brought momentous changes in the Horn of Africa. The 30-year secessionist war in Eritrea ended as the EPLF took control of Asmara, the capital of Eritrea, on May 26 and set up a separate transitional administration. Two days later, the EPRDF entered Addis Ababa, seized state power, and formed a transitional government. The two liberation movements maintained strong relations in the initial years after their military victories. Ethiopia accepted Eritrea's overwhelming vote for independence in a referendum held in 1993 and sought support from the UN for recognition of Eritrea's sovereignty. The amicable interactions were embodied in a comprehensive agreement in which the parties agreed to 'cooperate closely on all matters relating to international relations and work towards adopting common strategies and common policies on important regional and international political and security issues to achieve common objectives'. ${ }^{31}$ The two states agreed not to engage in acts that threaten the peace and security of each party, including sheltering groups engaged in undermining the stability of either country through insurgency, propaganda or any other subversive activities. In the economic sphere, Eritrea allowed the use by Ethiopia of Assab and Massawa as free ports, and birr, the Ethiopian currency, served as a common currency.

However, rifts hidden temporarily by the post-victory amity soon reappeared. The first core issue related to economic and trade relations. Ethiopia

${ }^{31}$ They formed what came to be known as the alliance of the frontline states (comprising Eritrea, Ethiopia and Uganda and supported by the USA) against the "Islamist" regime in Sudan; and Ethiopia provided diplomatic backing to Eritrea in its clash with Yemen over the control of the Hanish archipelago in the Red Sea. 
decided to import fuel instead of using the Assab refinery which had major financial repercussions on Eritrea, which in 1997 introduced its own currency, the Nakfa ${ }^{32}$, "after seven years of the privileged use of the birr" (Abbink 1998:559). Ethiopia followed by issuing a new currency, "thus declaring all birr still held by Eritrea, intended for use in purchasing Ethiopian goods and services from the Ethiopian market, where the weak naqfa would not be popular, as null and void" (Ibid.), and began taking steps to formalize the largely irregular trade practices that had existed as a result of the informal, party-to-party relationship between the two movements. The Ethiopian government rejected Eritrea's proposal for the two currencies to have equal value and to be used in both states.

The second issue over which a series of disagreements emerged pertained to border demarcation. During the insurgency, the TPLF and the EPLF had chosen to defer border issues until after the end of the armed struggle. After Eritrea alleged that a local Ethiopian militia entered its territory in 1997, both states agreed to settle the border issue peacefully through a joint border commission. However, in May 1998, Eritrean forces moved into the small village of Badme and its environs which at the time was under Ethiopian administration. Eritrea refused Ethiopia's demand for the immediate withdrawal of its troops (Abbink 1998). What began as smallscale border skirmishes escalated into a full-blown conventional war that lasted for two years and claimed the lives of an estimated 70,000 to 100,000 people and displaced over one million people (Gray 2006).

\footnotetext{
32 Until the introduction of Nakfa, the two countries had used the Ethiopian Birr as their common currency.
} 
The international community was taken by surprise by the war between the hitherto close allies and embarked on a series of concerted effort to settle their hostilities through dialogue. The USA and Rwanda, followed by the OAU, put forward peace proposals calling for the immediate withdrawal of Eritrean troops from the disputed areas and the reinstitution of the status quo ante (OAU 1998). However, these attempts failed mainly due of the unwillingness of the Eritrean government to withdraw from the territories it occupied, although Ethiopia accepted the terms of the proposal (CNN 1998; Gilkes 1998). Instead, Eritrea called for direct talks to precede any withdrawal of its troops, whereas the Ethiopian government refused to enter into any dialogue before Eritrea withdrew its troops from territories occupied on or after the conflict started. In light of the failure of the mediation efforts, the UN Security Council imposed arms embargo on both countries in January 1999 (Resolution 1227) and in May 2000 (Resolution 1297). This move came into effect late in the conflict after both countries had already amassed stocks of weapons, and for failing to stop deliveries of arms and military equipment based on contracts entered into before the conflict.

The two countries took advantage of the protracted peace effort and the pause in fighting to bolster their military in preparation for what seemed an inevitable showdown. They continued to entrench their positions along the fronts; mobilize their population for total war; amass troops along the disputed areas; and engage in frenzied spending to modernize their military. The confrontations centered on the battlefields of Badme (West), Zalambesa (Central) and Bure (East) fronts between 1998 and 2000. The military stalemate was broken when Ethiopia 
launched an offensive in February 1999 and recaptured the symbolic town of Badme (BBC 1999). In light of the military setbacks, Eritrea finally accepted the OAU Framework Agreement and the Technical Arrangements to implement it. However, it was the turn of Ethiopia to refuse to proceed with the implementation demanding the return of all its territories and that Eritrea declare recognition of Ethiopia's sovereignty over the contested territories (Gray 2006:702). A year-long lull in fighting ensued together with fresh but futile activity to broker peace. Finally, Ethiopia recaptured all the remaining territories occupied by Eritrea after a second massive offensive in May 2000. Following this, the Ethiopian government officially announced the end of the war (Tran 2000).

In June 2000 Ethiopia and Eritrea signed a Cessation of Hostilities Agreement under the auspices of the OAU. The Agreement paved the way for a ceasefire and a Temporary Security Zone (TSZ) 25 kilometers deep into Eritrean territory to be patrolled by a UN peacekeeping mission - United Nations Mission in Eritrea and Ethiopia (UNMEE) (United Nations 2000). Subsequently, the two countries signed an internationally brokered peace accord in Algiers in December 2000 (Canada 2000). According to the peace treaty, Eritrea and Ethiopia agreed to submit their disputes to three entities working independently from each other. First, the OAU was requested to "set up an independent, impartial body to look into, and report on, the morass of events surrounding the origins of the conflict" (Plaut 2001:126). Second, a neutral, five-member Eritrea-Ethiopia Boundary Commission (EEBC) was established with a mandate to delimit and demarcate the boundary based on pertinent colonial treaties between Italy and Ethiopia (1900, 
1902, 1908), applicable international law and the 1964 OAU decision to keep colonial boundaries unchanged (Art. 4.2). It was agreed that the decisions of both commissions would be final and binding. Third, the Eritrea Ethiopia Claims Commission (EECC) was set up to decide, through binding arbitration, on all claims for loss, damage or injury related to the conflict and resulted from violations of international humanitarian law, and also investigate the causes of the war. (Art.

\section{$5.1)$}

The Border Commission passed its 125-pages decision in April 2002 awarding Bure and Zalambesa to Ethiopia but, more significantly, handing Badme, the symbolic flashpoint for the entire war, to Eritrea (EEBC 2002). The decision by the EEBC to award Badme to Eritrea looked to support the claims by the Eritrean government that it had gone to war in defense of its territory and Ethiopia had been the aggressor. ${ }^{33}$ For the Ethiopian government, however, losing the symbolic territory to which its troops paid with their lives, and which it regained through costly military victory proved difficult to accept. The fact that Badme had been administered as part of Tigray - the home region of the TPLF, the dominant group in the ruling government coalition EPRDF - further complicated the Ethiopian regime's position (Crisis Group 2008).

Therefore, the Ethiopian government rejected the EEBC decision and appealed for review, although the treaty clearly specified the Commission's

\footnotetext{
${ }^{33}$ In 2005 the EECC found the State of Eritrea to be in violation of international humanitarian law for unlawfully invading the flashpoint of the conflict, Badme, which, before the war, was peacefully occupied by Ethiopia. According to the verdict, the border conflict started when, on 12 May 1998, Eritrean forces invaded some territories under the peaceful control of Ethiopia.
} 
decision shall be final and binding and that each party shall comply with the border as determined. Ethiopia requested any border demarcation should take into account human and physical geography. According to the Ethiopian government, the decision to award Badme to Eritrea would lead to separation of families and would adversely affect communities that might find themselves living on the wrong side of the border or which would lose access to resources such as farmland and water. The Commission on its part argued that the Algiers Agreement expressly committed itself to use only colonial treaties as the basis for making decision excluding existing administrations, humanitarian imperatives, or concerns of local human needs. Moreover, the Commission pointed, out both states had agreed, at the outset, that the decision of the commission would be final and binding and there is no legal basis for it to revisit the decision (Irin 2002).

In 2005, the Ethiopian government issued a five-points peace plan accepting, in principle, the EEBC decision, which it still maintained was unjust and unlawful. Ethiopia continued to maintain that actual demarcation should be preceded by negotiations on minimizing impacts on communities or on addressing normalization of relations between the two countries (Lyons 2009). Eritrea insisted that demarcation must precede any negotiation, dialogue or other process meant to normalize relations, or even amendment to alleviate the adverse human effects of the demarcation. Thus, Ethiopia stopped cooperating with the EEBC by suspending its financial contribution to the Commission and refusing to provide assistance for the Commissions demarcation efforts. In March 2005, the Boundary Commission announced the suspension of its work, citing Ethiopian non- 
cooperation. On 30 November 2007, the Commission dissolved itself unable to demarcate the border on the ground. Upon its dissolution the Commission stated, "Until such time as the boundary is finally demarcated, the delimitation decision of 13 April 2002 continues as the only valid legal description of the boundary" (Crisis Group 2008).

The Eritrean government for its part took steps to impede the operations of UNMEE in frustration at Ethiopia's refusal to accept the commission's decision and the UN's failure to put pressure on Ethiopia to comply with the decision. In October 2005, Eritrea banned UNMEE helicopter flights, compelling the force to consolidate its observation posts from 40 to 18 , reduce its capacity to monitor the TSZ by close to 60 per cent and suspend its mine clearance activities. ${ }^{34}$ This was followed in early December 2005 by a decision to expel UNMEE personnel coming from eighteen North American and European countries (Lacey 2005). In early 2008, Eritrea imposed a complete halt of fuel deliveries, crippling the peacekeeping activities. Finally, the UN Security Council terminated the peacekeeping mission in July and UNMEE forces withdrew in the after it was ordered to leave Eritrean territory by the Eritrean government and Eritrean troops re-occupied the TSZ (Irin 2008).

Both countries took actions that impeded the activities of bodies established as part of the peace deal that they signed. With regards to Ethiopia, Pratt (2006) opines that "primary responsibility for the current state of affairs must lie with the

\footnotetext{
${ }^{34}$ The UN Security Council called on Eritrea to lift the restrictions (Resolution 1640).
} 
Ethiopian government [and] the fact remains that it has clearly gone against its commitment to accept the [border commission]'s decision as final and binding and to allow the commission to demarcate the boundary identified in its delimitation decision". On the other side, the string of obstacles Eritrea placed on the UNMEE resulting in its dissolution is in breach of its pledge in the Cessation of Hostilities agreement to not undermine the peacekeeping mission. Therefore, both countries stand in violation of international law and treaties they entered into willingly. However, although Eritrea's assertion that Ethiopian forces are occupying its sovereign territory holds strong legal credence, it is the Eritrean actions that often generate widespread international condemnation. Fifteen years after the EEBC passed its judgment, the status quo remains intact as Ethiopia occupies territory that was awarded to Eritrea. The core question therefore is how Ethiopia managed to defy the decisions of an international body formed with its concurrence within the context of a legal predicament where there seems to be no room to maneuver.

One explanation is the difference in diplomatic skills between the two countries. Events since the Commission's decision have demonstrated Ethiopia's vastly superior skill in diplomacy. This does not hide the fact that "Ethiopia's acceptance of the Algiers Agreement, which placed in jeopardy the gains from victory in the bitter war against Eritrea, was a remarkable piece of diplomatic ineptitude that could only have resulted from overweening self-confidence" (Clapham 2009:189). However, once the Boundary Commission decisions were made, Ethiopia's refusal to comply should have lost it friends and influence. But a strong tradition of diplomacy has been put to excellent use, enabling Ethiopia to 
overcome what was, from a legal standpoint, a fundamentally weak position. Ethiopia's highly advantageous position within the global and continental institutions was "greatly helped by the long-established diplomatic capacities of the Ethiopian state apparatus, and its ability to present its own interests as the answers to other actors' problems" (Ibid).

Second, Ethiopia's' diplomatic skill in avoiding the implementation of the EEBC decision contrasted with Eritrea's incompetence at diplomacy, which has lost Eritrea the international goodwill it enjoyed in the war with a dominant neighbor. In the first years after the Commission made its decision, the international community's pressure for a speedy acceptance and implementation was directed at Ethiopia, even from close allies such as the US and UK (Irin 2004a and 2004b). ${ }^{35}$ However, Asmara's insistence on the implementation of the Commission's decision as the single most important issue of its foreign policy eventually led to estrangement from its allies. Cliffe states, "the prickly, ultimatumridden way Eritrea conducts its foreign relations [demonstrates] a 'diplomatic deficit"'. For a small country that has the enforcement of the boundary decision as the single central issue of its foreign policy and "is seeking to get international backing, or at least reduce the advantage that Ethiopia has in this regard, its stance is so often counter-productive" (Cliffe 2009). As a result, "Eritrea is today almost hermetically sealed from the outside world...in a permanent state of emergency,

\footnotetext{
${ }^{35}$ The UNSC in its resolutions 1430 (2002), 1466 (2003), 1507 (2003), 1531 (2004) expressed concern about Ethiopia's rejection of significant parts of the Commission's decision, and its current lack of cooperation with the Boundary Commission and it urged Ethiopia to show the political will to reaffirm unequivocally its acceptance of the Boundary Commission's decision, and take the necessary steps to enable the Commission to demarcate the border without delay. (Gray 2006:709)
} 
with its youth almost entirely conscripted into the trenches, the free press has been stifled, the opposition - even within the ruling party - has been crushed, and assistance from the West and the UN is spurned" (Healy 2008).

Moreover, Eritrea's external relations seems to have been preoccupied with undermining Ethiopia in the region. According to Healy (2008:21), since 1998 “Eritrea's regional policy calculations and strategies are singularly designed to weaken Ethiopia politically both domestically and in its regional roles". Reid concurs, "to a very real degree, Eritrea's regional foreign policy has one overriding aim, the undermining and eventual destruction of the regime in Addis Ababa". To this end, Eritrea has consistently provided support for diverse set of groups ranging from ethno-nationalist insurgencies to radical Islamist groups. Within this context Somalia has emerged as a stage for proxy warfare between Eritrea and Ethiopia. In Somalia, any administration, group or peacemaking effort Ethiopia supports is automatically opposed by Eritrea regardless of their ideological predilection or political program. Furthermore, Eritrea openly aligned with countries hostile to Ethiopia (and in some cases hostile also to Ethiopia's Western allies), in particular to Libya, Iran, Egypt and Qatar.

Eritrea's unorthodox alignment with Somali Islamists has some logic in that it is consistent with the deeply ingrained realist adage that the enemy of my enemy is my friend (Lyons 2009). By arming, training and financing major insurgent groups in Somalia, Eritrea intends to weaken successive transitional governments in Somalia that it sees as closely allied with Ethiopia and the US. This will indirectly prompt a threat to Ethiopia because instability in Somalia can spill over to Ethiopia 
through Ogaden. Eritrea's action aims to reduce Ethiopian influence in the region by creating a second front to overstretch Ethiopia security forces with the ultimate goal of compelling Ethiopia to settle the outstanding border issue or accept the EEBC ruling. ${ }^{36}$ Cliffe ( 2008:327) argues, "It would be surprising in the present context if Eritrean tactics in the region and in Ethiopia itself didn't take advantage of the stretched nature of Ethiopian security forces". Reid also argues that the Eritrean support for the UIC with Somali insurgents was more tactical than strategic and it "was not motivated by any ideological reorientation, but from a tactical need to support whichever group could oppose the Ethiopian hegemonic projects". An Islamic state in Somalia would be a threat to the long-term interests of Eritrea because first, "the ruling party is a secular organization; and second because the country is also affected by tensions between Christians and Muslims (Reid 2009).

However, Eritrea's leadership's obduracy and unqualified support to any group opposed to Ethiopia put it on a collision course with much of the international community. "To insist that the settling of this one [boundary] issue must be the precondition to discussion of all other issues....has been at the root of [Eritrea's] relations with international actors such as UNMEE, would-be mediators from the US, EU and African Union, and IGAD and run counter to the country's long-run national interests (Cliffe 2008:326). First, supplying weapons to armed groups in Somalia, violated UN Security Council sanctions ${ }^{37}$ that imposed, among other

\footnotetext{
${ }^{36}$ Eritrea not only facilitated the formation of the ARS after the defeat and scattering of the UIC, but also provided shelter to the then two leaders of the former UIC, namely Sheikh Sharif (and Sheikh Hassan Dahir Aweys.

37 In January 1992 UNSC Resolution 733 unanimously adopted an arms embargo on Somalia in reaction to the ongoing conflict and deteriorating humanitarian situation. In June 2001 UNSC
} 
things, a travel ban and an arms embargo on certain groups in Somalia. ${ }^{38}$ It would not only affect Eritrea's international standing, but amounts to a material breach of international law. Second, support to groups and individuals designated as terrorists ran the risk of antagonizing the UN, and more importantly the US. The US Government warned Eritrea to refrain from supporting groups such as alIttihaad and al-Shabaab, both designated terrorist group, or run the risk of being designated as a state sponsor of terrorism. Eritrea was characterized as not an active partner on counter-terrorism program (Lyons 2009; Woldemichael 2018).

Third, by undermining internationally sanctioned peace processes in Somalia, and the administrations they produced such as the TFG, Eritrea alienated regional groupings such as IGAD and the $A U$, and countries that sent troops to Somalia under AMISOM. In 2007, after IGAD endorsed Ethiopia's controversial intervention into Somalia to remove the UIC, Eritrea suspended its membership accusing the regional grouping of subservience to Ethiopian and U.S. interests in the region (FDRE 2002). In 2009, IGAD called for sanctions against parties who continue to pose obstacles to peace and stability in Somalia through the provision

\footnotetext{
Resolution 1356 allowed for exemptions to the embargo for supplies of non-lethal military equipment for use in humanitarian operations. In July 2002 UNSC Resolution 1425 clarified the scope of the arms embargo, making clear that it prohibited the financing of arms acquisitions as well as the direct or indirect sale or supply of technical advice or military training. In December 2006 UNSC Resolution 1725 authorized the IGAD and AU member states to deploy a regional intervention force to protect Somalia's TFG and partially lifted the UN arms embargo on Somalia to arm and train the TFG security forces. In February 2007 UNSC Resolution 1744 limited the embargo to non-state actors (SIPRI 2019)

${ }^{38}$ The embargo has been violated by several countries including Eritrea and Ethiopia as verified by the periodic reports of a panel of experts and a monitoring group established by the UN Security Council to oversee the sanctions imposed on Somalia. The fact that sanctions were directed on Eritrea than Ethiopia signifies Ethiopia effective diplomacy adding to the feeling of abandonment by the Eritrean government.
} 
of assistance to the extremists, including foreigners who continue to cause mayhem in Somalia. The AU also took the unprecedented step of demanding targeted sanctions on Eritrea for alleged support of terrorist groups in Somalia and its destabilizing role in the region in general. Consequently, the UN Security Council passed Resolution 1907 in December of the same year placing an arms embargo on Eritrea, imposes travel bans on and freezes the assets of some of the country's top political and military officials. In 2011, after Ethiopia gave the UN Sanctions Group evidence Eritrean agents planned to bomb the AU summit in Addis Ababa, more sanctions were added.

A fourth and final explanation to Eritrea's isolation by the international community is Ethiopia's greater weight in the region as reflecting its larger size and population, its status among other countries in Africa, its position as a host to the AU and UN-ECA, and its standing with the US in the GWoT. Ethiopia has successfully used these advantages to win an indefinite suspension of the Commission's ruling. Healy (2008) argues that "Ethiopia is helped by the fact that it is a more open political system than Eritrea: it has elections, however flawed; it has an independent press, even if this is curtailed and journalists are locked up; and an administrative system to accommodate ethnic diversity." By 2006, escalating conflict in Somalia and the Ogaden, the post-electoral crisis in Ethiopia, Washington's increasing counter-terrorism interests in the region and concerns in Sudan with Darfur led to increased reliance on Ethiopian support for its policies and, as a consequence, a disinclination to press for implementation of the EEBC decision. Ethiopia's refusal to hand over the village of Badme, counter to the 
findings of the Boundary Commission, has come about as a result of 'unwarranted' political and diplomatic support provided by the US Government and the international community.

\section{Chapter conclusion}

This chapter started with the goal of establishing the case that Ethiopia's bi-lateral relations with Somalia and Eritrea validate its emergence as a regional power in the Horn of Africa. In Somalia Ethiopia has actively engaged in successive diplomatic efforts to reconcile warring factions and reestablish central authority in Mogadishu for reasons are not always altruistic. Ethiopia's major interest in Somalia is the recentralization of state power under a friendly regime that does not aim to export radical Islam in the region or resurrect Somalia's claim over the predominantly Somali region of Ogaden. In addition, Ethiopia has sought to limit the influences in Somalia of its regional foes Eritrea and Egypt, and limit opportunities for armed groups using Somalia as a springboard for attacks inside Ethiopian territory.

As a matter of strategy, Ethiopia has used both diplomacy and military force to secure its objectives. In terms of these objectives Ethiopia has largely succeeded but, has occasionally settled for sub-optimal outcomes. Diplomatic negotiations initiated or supported by Ethiopia have not led to the pacification of Somalia or the centralization of authority. Of all the regimes that came out of peace

processes the TFG (2006) has been the friendliest to Ethiopia. Its authority however was hampered since its formation. What is more, in 2008, Sheik Sheriff 
Ahmad, former leader the moderate leader of UIC, became President of the TFG, an outcome that was not to Ethiopia's interest. Successive military interventions of 2006 crippled Islamic groups in Somalia but did not lead to concentration of use of violence in the hands of a friendly central state. In 2006, the main military intervention, Ethiopia was bogged down in urban insurgency. Public outrage over Ethiopia's heavy-handed tactics contributed to the rise of al-Shabaab, a group more radical than the UIC. And for a limited time, it intensified armed insurgency activity inside Ethiopian territory by ONLF. Both the insurgency in Ogaden and heavy casualties inside Somalia have politically and diplomatically damaged the Ethiopian government.

With regards to Eritrea, the cause of the $1998-2000$ war is debated often along the lines of supporters of the two regimes. For Ethiopia, Eritrea's aggression is an extension of a belligerent regional policy and its attempt to be the police of the region. Within five years after independence Eritrea had fought with Sudan over Sudan's support for Eritrean Islamic Jihad (1995), Yemen over the Hanish islands in the Red Sea (1996) and Ethiopia (1998). After that Eritrea also has sent troops inside Djibouti in 1998 (when Djibouti provided Ethiopia an alternative seaport) and 2008 (when Djibouti tried to mediate the TFG and ARS). The 1998 war is therefore a manifestation of the hegemonic aspirations of Asmara (Tadesse 2002). On its part Eritrea accuses Ethiopia of hegemonic aspirations in the Horn of Africa. The EPRDF's policy towards Eritrea is an extension of previous Ethiopian regimes attempt to forcefully annex Eritrean territory and gain access to the sea (lyob 2000). 
Be that as it may, the military victory over Eritrea has been a turning point for Ethiopia's regional dominance. A main reason Ethiopian troops crossed into Somalia in 2006 was to counter the threat of Eritrea's support for the UIC. The Eritrean threat has forced Ethiopia to pursue an assertive regional policy diplomatically (through IGAD or multilateral diplomacy with Sudan and Yemen) or militarily (Somalia invasion in 2006) (de Waal 2015). Similar to Somalia, however, Ethiopia did not get all its way in its objectives. Despite military victory, the EEBC awarded the flash point of the war - Badme - to Eritrea. Ethiopia has however successfully circumvented its implementation. And, Ethiopia's attempt to organize Eritrean opposition groups to topple the regime in Asmara has been unsuccessful.

Apart from bi-lateral dominance, Ethiopia's role in Somalia and Eritrea has signified the influential role it plays at the multilateral level through IGAD. Kenya and Uganda seem to prioritize the East African Community (EAC), leaving Ethiopia to pursue its interests in IGAD, whose failurewith regards to the 'no war, no peace' situation between Eritrea and Ethiopia is particularly revealing of Ethiopian influence in the organization. Unsurprisingly, Eritrea condemns this domination. Bereketeab opines that "any discussion that would offend Ethiopia could not be entertained within IGAD". This view is shared by Tadesse who stated the EPRDFled government "use[s] organizations as a vehicle to pressure and isolate hostile countries". In 2007, IGAD's Council of Ministers, at a meeting in Nairobi, unanimously approved Ethiopia's action in Somalia and its support for the TFG. Eritrea strongly denounced IGAD's decision, accused the organization of impartiality and suspended its participation. In addition, IGAD meetings are often 
held in Addis Ababa instead of its headquarters in Djibouti. An Ethiopian has served as the chair of IGAD every year since 2008, and while IGAD is supposed to elect a new chairperson at each of its annual summits, there has been no summit since 2008 when Ethiopia took the chair. In short, the chapter demonstrated Ethiopia's active and assertive role in the Horn of Africa is characterizable as a regional power, but with sub optimal outcomes. 


\section{Ethiopia as a Regional Power - Projection of interest, Provision of public goods and Perception of influence}

The previous chapter detailed the proactive role Ethiopia plays in contemporary Horn of Africa by using the cases of Somalia and Eritrea. These cases demonstrate Ethiopia has increasingly assumed an activist regional policy, has managed to view its national interests through the regional optic and has had a powerful impact on the behavior of actors in neighboring states. Chapter 2 was the first part of my contention that Ethiopia has emerged as a regional power in the Horn of Africa. Chapter 3 extends this line of argument and demonstrates Ethiopia's growing power by using projection of its regional interest, provision of public goods and perception of rising influence in the region. The purpose of chapter 2 was to establish one aspect of the thesis: to establish the argument that Ethiopia can be regarded as a regional power. However, determining the existence or absence of a regional center of power leads us to an examination of how regional powers are conceptually defined. Definitions give us the analytical tools to determine when and where a state can be regarded as a regional power.

Nolte (2010) provides a comprehensive and compelling list of attributes a regional power is expected to have: A regional power is defined as a state which articulates the pretension (self-conception) of a leading position in a region that is geographically, economically and political-ideationally delimited; which displays the material (military, economic, demographic), organizational (political) and ideological resources for regional power projection; and, which truly has great influence in regional affairs (activities and results). In addition, it is expected that a 
regional power is a state which is economically, politically and culturally interconnected with the region; influences in a significant way the geopolitical delimitation and the political-ideational construction of the region; exerts this influence by means of regional governance structures; defines and articulates a common regional identity or project; provides a collective good for the region or participates in a significant way in the provision of such a collective good; defines the regional security agenda in a significant way; leading position in the region is recognized or at least respected by other states inside and outside of the region, especially by other regional powers; is integrated in interregional and global forums and institutions where it articulates not only its own interests but acts as well, at least in a rudimentary way, as a representative of regional interests.

It is, however, difficult to find a regional power that ticks all the boxes of such a maximalist and idealized definition. Thus, a more parsimonious definition of a regional power proposes three defining qualities of regional powers: a) that these states belong to the region considered; b) that they display a superiority in terms of power capabilities, that is, that they possess the largest power share in the region and, c) that they exercise some kind of influence on the region. Being part of the physical geographic of a region is self-evident. With regards to capabilities, states must possess a significant share of the region's material power resources in order to qualify as a regional power (Frazier and Stewart-Ingersoll 2010). ${ }^{39}$ The cases of Somalia and Eritrea were meant to show the third element

\footnotetext{
${ }^{39}$ The distribution of material capabilities among countries of the Horn of Africa will be the subject of chapter four.
} 
of the definition - that is, how regional powers' material preponderance translates into and manifests itself in their interaction with secondary states in the region. The possession of a relatively high share of system capabilities both allows states to play a broader set of functions within the system and increases their interest in doing so.

Prys (2012) has developed an analytical framework for determining the existence of a regional power and for developing typologies of regional powers. Her analytical framework looks at strategies regional powers use in their approach to regional leadership - what she termed the three P's: the outcome dimension or projection, the interactive dimension or provision and the cognitive dimension or perception. A state that is considered a regional power is able to project its interests and values on the region, provide different kinds of public goods to the states in the region, and have the cognitive self-perception and acceptance, both by the power and its followers, of its dominant role in the region. In her book on South Africa and India, Prys uses this framework to determine the dominant role South Africa and India play in their respective regions and what kind of regional power each country is from a set that includes regional detached powers, regional hegemons, and regional dominators, in order of capability and engagement. Destardi (2011) uses a similar framework to develop a taxonomy of the behavior of regional powers into leadership, hegemony and imperial. The purpose of this chapter is to determine Ethiopia's position as a regional power; an analysis of which typology Ethiopia fits is beyond the purview of this chapter and this dissertation. Even so, the three P's framework Prys developed can serve as a 
suitable scaffold to establish the argument that Ethiopia is a regional power in the Horn of Africa.

\section{Projection of Interest}

A regional power is distinguished by its ability to project its interests and values on the rest of the states in the regional sub-system. According to Hurrell, a shift in regional polarity arises when "the regional state is so overwhelmingly dominant that it can enforce its will, or because it succeeds in creating consensual hegemony within a region - maybe by providing economic benefits, or by underpinning regional security, or by claiming to embody a particular view of the world or set of values. Or it might arise when its regional position is actively supported by those outside the region" (Hurrell 2007:140) The strategy through which the powerful state advances its interest - coercion, material benefits, socialization, ideational influences - determines what type of regional power it is. However, in general a state's success in setting its national interest and consistently carry them out is a key indicator of regional powerhood.

As the two case studies established, the Ethiopian government has employed a range of strategies in its regional dealings in its effort to further Ethiopia's national interests. A key document with regards to Ethiopia's external relations is the Foreign Affairs and National Security Policy and Strategy White Paper (hereafter "white paper") issued in 2002 (FDRE 2002). According to Mohammed (2007) the white paper identifies three concentric rings of national security concerns (FDRE 2002:61). In the innermost ring are local issues in 
sensitive areas that have the potential to spark conflicts which may escalate and expose the country to external meddling and intervention (p.56). In the middle ring are the most immediate threats to Ethiopia's security within the regional strategic context that can stem from neighboring states through invasion or destabilization, the latter by supporting rural guerrillas or urban terrorists (p.60). These include vulnerabilities to militant Islamic groups based in Sudan and Somalia, and the threat Eritrea poses to Ethiopia. The outermost ring is the strategic challenge posed mainly by Egypt, Ethiopia's principal rival for control over the Nile, and a possible future militant Islamist state in the Arabian Peninsula (p.79).

The Ethiopian government has utilized a mix of diplomacy and coercion to thwart regional threats. In the case of Sudan, Ethiopia used direct military pressure and support for the Sudanese opposition. As a result, Sudan expelled most militant groups and adopted a strategy of seeking peace in Southern Sudan. In Somalia, Ethiopia took direct military action against extremist groups on Somali soil (See Chapter 2). Diplomatically, Ethiopia supported efforts to rebuild a central government for the country, albeit one under Ethiopia's de facto influence. Mohammed argues (2007) that the main threat to Ethiopia has come from Eritrea which has required Ethiopia to maintain a large standing army with the capacity to project across its national borders. Eritrean-sponsored insurgencies in the southeast and south-west regions of Ethiopia have proven to be a constant challenge. After its army was shattered in 2000 , Eritrea is now banking on the even greater vulnerability of the neighboring states to provoke Ethiopian destabilization through insurgency. 
Ethiopia also harbors a strategic concern over radical Islam in Egypt and the Arabian Peninsula. Whereas Ethiopia's history has been marked by mutual respect and tolerance among faiths, Mohammed underlines that it "has needed to keep a watchful eye on the activity of foreign militants in the Horn, who regularly introduce destabilizing agendas. An attempt by radical Islamists to create Islamic states in north-east Africa, fully backed by the power and wealth of the Gulf states, would be a profound threat to Ethiopia. However, the activities of those militants actually present in the Horn - located in Sudan in the 1990's and in Somalia recently - remain a smaller-scale threat". (Ibid.) The rise of the UIC in Somalia is considered to be a confluence of Ethiopia's strategic and immediate regional challenge - a Taliban-like radical Islamic state in the vicinity of the Horn of Africa getting military and diplomatic support from Eritrea and Egypt.

According to the national security white paper, Somalia's persistent statelessness means the realistic goal of Ethiopia's policy towards Somalia should be "damage-limitation" to guarantee that the instability does not imperil Ethiopia's interests and the region through three alternative strategies (FDRE 2002:80). The first option is helping the relatively peaceful and stable regions of Somalia that do not shelter extremists and terrorists in order that the relative peace they enjoy is maintained and even strengthened. Shoring up ties with regions such as Somaliland and Puntland in security, trade, and transport is to Ethiopia's advantage and benefits Somalis living in the area. The second option involves creating the requisite capability to defend and foil any attacks from "terrorist, extremists and anti-peace elements originating from Somalia". The white paper 
stipulates that Ethiopia will continue to be exposed to various dangers as long as peace and stability elude Somalia and calls for vigilance in its defense policy (p. 81). The third strategic alternative recognizes the importance of multilateralism and underlines "working in cooperation with the Somalia people and international communities to weaken and neutralize any force coming from any part of Somalia to perpetrate attacks against Ethiopia." (p. 82). In an attempt to reconcile the principle of non-interference in other countries affairs, the paper argues "While maintaining the principle of non-interference in the internal affairs of Somalia, we have to ensure our right to safeguard our peace and defend ourselves" (p. 82).

Ethiopia's interest in Somalia is encapsulated by the four justifications the Ethiopian Federal parliament gave in its declaration of war on the UIC in 2006. First, a non-friendly Somalian state strong enough to renew the irredentist ambition is inimical to the territorial integrity of Ethiopia. Second, a Somalian government harboring Ethiopian insurgents with the intent of destabilizing Ethiopia is a threat to the regime and to the country. Third, the rise of a radical Islamic rule intent of spreading its version of Islam in the region imperils the secular political order. Fourth, a Somali regime with tactical or strategic alliance with Eritrea would be dangerous to Ethiopia as long as the no war no peace situation with Eritrea festers on. A strong and hostile Somali state would be the worst conceivable option for Ethiopia's interest and a strong and friendly one would be preferrable. The government in Addis may have opted for the second-best solution - a weakened state which is dependent on Ethiopian support. 
Ethiopia's capacity to consistently pursue its regional and national priorities in Somalia supports the contention that Ethiopia has emerged as the region's fulcrum of power and as a principal power broker in Somali politics. Ethiopia's successes could be seen in four distinct aspects of Somalia's politics. First, by undermining groups sympathetic to and supported by its regional foes Eritrea and Egypt, Ethiopia has been able to steer the directions of consecutive peace processes and their outcomes. A case in point is the TNG which, despite broad international support, could not even assume control over Mogadishu largely due to Ethiopia's midwifery role in the formation of a rival group - the SRRC. Second, Ethiopia has managed to shape the political trajectories of Somalia. The Eldoret/Mbaghati peace process demonstrates the extent of Ethiopia control of the peace process to the extent of excluding groups supported by regional foes.

Third, Ethiopia has managed to project its political values through the adoption of federalism as a government structure in Somalia. Fourth, Ethiopia managed to isolate and exclude clans and religious groups that are opposed to its interest from dominating the political and peace processes. With regards to the Eldoret peace process, Crisis Group (2005) states “...one of the losers at Eldoret is the Islamist lobby. Neither al-Islah nor its militant relation, al-Itihaad, is well represented among the delegates... Overall, the Eldoret Conference has denied Somalia's Islamists the kind of opportunity they enjoyed at Arta to boost their political influence". Furthermore, While the TNG had relied principally on Hawiye support - especially the president's Habar Gidir Ayr sub-clan - that new government, the TFG, came to be perceived as a vehicle for Darod interests, 
especially those of President Yusuf's Majerteen clan. Writing in 2003, while the peace conference was still going on, the Crisis Group reported that the feeling among participants was that "Ethiopia has two agendas, either to get the government they want or to prevent any government from coming into being...Ethiopia is working toward the formation of a transitional government led by Puntland Chief Colonel Abdillahi Yusuf'40.

With regards to Eritrea, when the 1998-2000 war interrupted postindependence cordial relations, the core and immediate interest of Ethiopia has been to regain the territories taken by force. The decisive military victories in 1999 and 2000 fulfilled this immediate objective. Subsequently, although Ethiopia's expectation that the regime in Asmara would not last long after the military defeat never transpired (Mohammed 2007), Ethiopia has pursued a successful campaign of alienating and containing Eritrea. The strategies included forming an alliance with Sudan and Yemen, two states that have borne the brunt of Eritrea's aggression. The objective of Tripartite Sanaa Co-Operation Forum is ostensibly to coordinate anti-terrorism activities of the three states following the 2000 attack by al-Qaeda on USS Cole in the Arabian Peninsula. However, Eritrea has described the alliance as an "axis of belligerence" and accused the countries of conspiring against it (Irin 2003).

\footnotetext{
40 Yusuf earned his credentials as anti-Islamist campaigner by fighting and defeating al-Ittihad militarily in northeast Somalia in 1992 and has lived on this success ever since. As president of the regional government of Puntland, he cooperated closely with the Ethiopian and American intelligence services, and many observers expected him to win the enthusiastic endorsement of both governments.
} 


\section{Projection of Ethiopia's values: Federalism in Somalia}

Projection denotes activities that promote the regional power's vision and values for the region, through bi-lateral engagements, activities and initiatives at the multilateral level, the creation of new regimes and institutions and shaping their agendas, and financial and economic aid. A more immediate form of value projection according to Prys (2010) is "the direct construction of a similar political system in the secondary states through the mediation of conflicts, training of administrative and police officers, but also forms of business cooperation and rules for corporate governance brought in by the private sector".

After a long history of concentration of authority in the central government, Ethiopia in 1995 adopted a federal political structure. Ethnic federalism was preferred with the view to finding a political solution to social mobilization and conflict on the basis of ethnic identity. Ethiopia has since been accused of pushing for the adoption of federalism as a solution to the conflicts in regional countries mainly in Somalia and South Sudan.

As an example, a sticking point during the Eldoret/Mbaghati peace negotiations related to the constitutional issue of accepting a unitary or a federal government structure for Somalia. Those who supported the latter sought a clanbased federal system, an extension of the building blocks approach espoused by Ethiopia. This approach envisaged a federation of four or five regions within Somalia - Somaliland, Puntland, the Bay-Bokool region in south-central Somalia, and Jubaland in the southwest - each populated by a major clan or coalition of clans. (See Map) Federalism is centered on the belief that decentralization would 
prompt minimum opposition since de facto administrations have demonstrated a preference for autonomy, and had evinced the ability to subsist on local means with little need for financial support from the central government or the increasingly disenchanted international donors. For many Somalis, the legacy of the pre-1991 political system is an enduring distrust of a dominant central government. A federal system would be a bulwark against the return to an authoritarian government (Mosley 2015).

It should be noted here that the projection of values could indirectly imply projection of interest. The proponents of unitary system fear a federal structure would potentially weaken Somalia as a state and as a nation. Reorganizing the country along clan lines could intensify clan consciousness and exacerbate existing tensions. Ordinary Somalis would identify primarily with a clan-based ministates, preventing the re-emergence of a sense of national identity, and that clanbased regions would be mired in unending conflict with one another (Menkhaus 2006). They assert that federalism is tantamount to "Balkanisation", leading to the formation of what Menkhaus (2006) called "clanustans", leaving Somalia divided into clan enclaves and susceptible to divide and dominate tactics by neighbors, especially Ethiopia. In other words, decentralization would balkanize Somalia destroying any hope of reviving Somali nationalism and providing neighboring Ethiopia with ample opportunity to engage in divide and rule tactics. Unitarists strongly believe federalism is but an Ethiopian ploy which fears the re-emergence of a strong, united Somalia and so seeks to perpetuate instability and division. 
Although local backing for decentralization or even federalism does exist, the unitarist's fear of Ethiopia's support for Federalism is not without foundation. In general, regional actors have actively sponsored the bifurcation of the reconciliation process into two competitive approaches of centralism versus federalism. The Puntland state of Somalia in the northeast, formed after the Sodere conference in 1996, became the epitome of the building block approach actively sustained by the Ethiopian government, IGAD and the EU. The Benadir administration in Mogadishu which came out of the Cairo process has been the center of the centralized approach supported by Arab states and strongly disapproved by Ethiopia. The TNG represented a unitary and centrist vision of the Somali state and it received the approval of Egypt; conversely the TFG which succeeded the TNG adopted Federalism even in its label (Bryden 2013). In the words of Doornbos (2002:104-105), Ethiopia, concerned with instability along its border with Somalia and the fear of a strong neighbor, perhaps unintentionally, supports "a decentralized, possibly federal or confederal state framework". To that end,

...Ethiopia has gone the furthest in its non-official recognition of Somaliland ${ }^{41}$ and in entering into agreements for cooperation in various fields such as aviation...Eritrea, a unitary state par excellence, prefers a strong centralized authority in Somalia as an

\footnotetext{
${ }^{41}$ Both Somaliland and Puntland are widely perceived by Somalis as Ethiopian creations, based on the intention to balkanize Somalia. As a result, many Somalis argue that Ethiopia seeks a weak and disunited Somalia which will not pose a security threat. Ethiopia maintains strong relations with Somaliland going back to the 1980s. Ethiopia provided military support to and a base for the Somali National Movement (SNM), which fought against Siad Barre's regime in northern Somalia (Arieff 2008). Ethiopia also established a close working relationship with the autonomous administration of Puntland. Again, relations between the two began in the 1980s when Ethiopia provided weapons and training for the Somali Salvation Democratic Front (SSDF), led by Abdullahi Yusuf Ahmed, who later became Puntland's first president and of the TFG in 2004.
} 
additional support vis-a-vis Ethiopia...Egypt sees a strong Ethiopia as a first order threat to its hydrohegemony over the Nile and sees the reconstruction of a strong state in Somalia as one of its key pillars of regional strategies.

At the domestic level, the debate between federalism and the unitary state tends to be closely linked to the perceived advantages each option affords to one's clan. Clans such as the Rahanweyn, which are relatively weak politically, but claim as their home territory some of the most valuable riverine and agricultural land in the country, strongly support a federal solution. Some minority clans such as the Digil Mirfille define themselves in terms of their shared experience of marginalization and persecution at the hands of powerful clans and forcefully advocate regional autonomy. They actually advocated for federalism even before independence in 1960 (Bryden 1999; Sufi 2003). Conversely, some lineages, especially the Hawiye clan-family, and the Habir-Gedir sub-clan, hail from the arid and remote central regions of Somalia but now dominate the political and economic life of the capital city, Mogadishu. They are fierce advocates of a more unified system of government (Bryden 2013; Menkhaus 2006; Doornbos 2002).

As stipulated in Chapter 2, the charter drafted at the 2004 Kenya peace talks enshrines the principle of decentralization through federalism, as does the Somalia Federal Constitution promulgated in $2012^{42}$. Since 1999, when transregional administrations in Somalia were at their high point, during which

42 The Somali Federal Constitution fundamentally has decentralized characteristics. Article 48 creates two levels of government, the National Federal Government level and Federal Member State level, which is comprised of the Federal Member State governments, and local governments (Mosley 2015). 
Somaliland and Puntland were operational and a nascent Rahanweyn administration in Bay and Bakool regions looked promising (Menkhaus 2006), several other regional states were created including the Jubaland in the southeast with the support of Kenyan troops controlling the area; southwest Somalia (Bay, Bakool and Lower Shabelle) launched in June 2014; central Somalia (Galgadud and Mudug) in July 2014; Hiraan and Middle Shabelle administration in 2015. Hence, "For all its fragility and flaws, federalism in Somalia remains the dominant political process with which to engage. Even those opposed to the leadership or framing of the federal government continue (in the main) to contest their case within its framework" (Mosley 2015:6) Through the building blocks approach, and its support for the TFG, Ethiopia has pushed for a federal arrangement in Somalia, a pointer to its willingness and ability to export its values to create a region in its own image.

\section{Provision of Public Goods}

The establishment of hierarchical systems and the existence of a preponderant power, be it regionally or globally, are closely associated with the provision of public goods. Such public goods could be common defense and maintenance of peace and security, and economic benefits including an open trading system, the maintenance of a structure of exchange rates and serving as a "lender of last resort". The provision of public good derives from the Kindleberger's hegemonic stability theory. The origins of hierarchical realism can be traced to Charles Kindleberger's book entitled The World in Depression 1929-1939. Kindleberger 
argued the spread of financial collapse, economic crises, and political instability during the Great Depression of the 1930's is explained by the absence of a hegemon; particularly, Britain's inability and the United States' unwillingness to maintain the global political economy regime of free trade and finance. Based on this theory, proponents of hegemonic stability theory argue that the rise (or decline) of a hegemonic power should be associated with the establishment (or collapse) and stability of international regimes. How a preponderant power provides such goods, whether it is acting as a benevolent hegemon or simply pursuing its own narrow interest, how it interacts with secondary states and exercises its power, whether it provides private goods or public goods and in general the strategy it adopts may determine the taxonomy or typology of its preponderance. However, that does not change the fact that a preponderant power regardless of the strategy it adopts, does project its influence/interest/values and vision.

\section{Provision of Economic Goods}

In relation to economic goods, none of the countries of the Horn have the resources to provide public good in the form of giving preferential trade arrangements, provide foreign aid, act as lenders of last resort, or maintain a stable currency and exchange systems. As the next chapter will show, neither Ethiopia nor any other regional state have the economic preponderance to play such a role. Without a strong economic base, none of them could really afford to pursue really vigorous, or ambitious foreign policies. However, Ethiopia has embarked on ambitions plan to give it a central role in the region's political economy and act as a center of 
gravity in terms of economic integration. The plan is embodied in a comprehensive policy and program of building the physical infrastructure, including road transport and in particular hydroelectric dams, with the view of becoming the region's transportation and energy hub.

Table 1. Ethiopia's Power Stations 100 MW and Above (Post 2000)

\begin{tabular}{llcc}
\hline \multicolumn{1}{c}{ Name } & Type & Year & Capacity (mw) \\
\hline Gilgel Gibe I & Hydropower & 2004 & 192 \\
Tekeze & Hydropower & 2009 & 300 \\
Tana Beles & Hydropower & 2010 & 460 \\
Gilgel Gibe II & Hydropower & 2010 & 420 \\
Ashegoda & Wind power & 2014 & 120 \\
Helele Werabesa & Hydropower & 2015 & 422 \\
Chemoga Yeda & Hydropower & 2015 & 278 \\
Genale Dawa III & Hydropower & 2015 & 256 \\
Gilgel Gibe III & Hydropower & Under construction & 1,870 \\
GERD & Hydropower & Under construction & 100 \\
Debre Birhan & Wind power & Under development & 1,000 \\
Corbetti & Geothermal & Under development & 300 \\
Aysha & Wind power & Under development & 100 \\
Assela & Wind power & Under development & 153 \\
Adama II & Wind power & Under study & 2,000 \\
Mandaya & Hydropower & Under study & 1,700 \\
Beko Abo & Hydropower & Under study & 1,600 \\
Karadobi & Hydropower & Under study & 1,472 \\
Gilgel Gibe IV & Hydropower & Under study & 896 \\
Baro & Hydropower & Under study & 800 \\
Border & Hydropower & &
\end{tabular}

Source: Cuesta Fernandez (2015).

Table 1 shows recent and ongoing projects to produce electrical power. Ethiopia's ambition is to fully meet domestic demands by 2023 and produce enough electrical energy for export to the region and beyond, and build a strong national economy that exports hydro-power to the east (Djibouti, Somaliland, Yemen), south (Kenya, Uganda, Tanzania and even South Africa), west (Sudan) and north (Egypt). ${ }^{43}$

43 "Overall, Ethiopia currently trades about $100 \mathrm{MW}$ with Sudan and 65MW with Djibouti, using $220 \mathrm{kv}$ transmission lines in both cases. As noted earlier, $500 \mathrm{Kv}$ and $400 \mathrm{Kv}$ transmission lines need 
Addis expects to sell at least 4,000 MW of power to regional partners by 2020 . "Such veritable hydraulic mission would not only transform the perception of Ethiopia from that of a poverty stricken country, dependent on outside assistance, to that of a leading state with resources that are valuable to the entire region, tying former rivals to Addis through hydropower flows. Ethiopia hopes in the long term to dominate the Horn through energy exports and 'responsible international behavior', setting it apart from its troublesome neighbors" (Verhoeven 2011).

Of all the hydroelectric projects, the Grand Ethiopian Renaissance Dam (GERD) is the most impressive and controversial. First, it is the largest in terms of power production of close to $6,000 \mathrm{MW}$ and upon completion is set to be the largest in Africa. Second, it is built on tributaries to the Nile and has created tensions with Egypt. In fact, it is often cited as reference for the shift of Hydrohegemonic power away from Egypt to the upper riparian states in general and Ethiopia in particular (Nasr and Neef 2016). Third, since international financiers often refrain from funding projects that would harm the interests of lower riparian states, the total cost of the project which is estimated at close to 5 billion USD (about tenth of Ethiopia's GDP) is funded from domestic sources such as government bonds and private donations, an indication of the state's mobilization capacity. Ethiopia is counting on GERD, and other power generation projects, to dramatically modernize its domestic economy through mass electrification and have a positive influence on

to be built between Ethiopia, Sudan and Djibouti to permit an increase in electricity exports. Ethiopia has also signed a Memorandum of Understanding with Kenya to deliver 400MW per year (from Gilgel Gibe III). It also envisages future exports of $1200 \mathrm{MW}$ to Sudan and $2000 \mathrm{MW}$ to Egypt. Somalia, South Sudan, Uganda, Somaliland and Eritrea are also potential clients" (CuestaFernandez 2015). 
regional relations through the export of surplus power to North and East Africa helping it to emerge as a regional hegemon through energy diplomacy.

The ambition to be a regional energy hub is a major part of the country's economic plans and strategies. It is part of an ambitious 25 -year master plan to transform Ethiopia into one of the main - and cheapest - power suppliers in Africa. The economic prize is potentially $\$ 1 b n$ a year in revenues from renewable electricity for Ethiopia and cheap supplies for a region short of electricity to power much needed industrial production and satisfy residential demand. Production and export of electrical energy "is part of its regional strategic plan...So [Ethiopia] becomes an energy superpower and along the way it also gains political clout in Africa" (Manson 2014). Former Ethiopian Prime Minister Hailemariam Dessalegn stated in a speech to the UN General Assembly in 2012, Ethiopia's energy policy operates

with full recognition of our responsibility, as the second most populous country in Africa, to contribute to regional integration. We foresee huge possibilities for bringing the countries of the greater Horn of Africa together. We have already gone some distance in playing a catalytic role in laying the infrastructural basis for consolidating economic ties with the countries of our region. The electric power interconnections and the road networks that we have built, and are in the process of building with Djibouti, Sudan, Kenya and South Sudan, are emblematic of our resolve to play our part in regional integration. We are confident that Somalia and others, without exception, will follow suit (Dessalegn 2012).

His sentiments are echoed by former Ethiopian Foreign Minister Tedros Adhanom,

we realize that our development will be more sustainable if there is a shared vision and action for peace and development in the whole of our sub-region. Ethiopia therefore attaches utmost importance to its relations with its neighbours and 
believes that creating the economic conditions of regional integration is vital. It is accordingly taking concrete action to promote regional integration by linking the sub-region with massive infrastructure developments. ...The huge electric power dams Ethiopia has been building are targeted not only to satisfy the domestic demand but also to supply the region with much-needed electric power. Ethiopia has already begun supplying Djibouti and Sudan with electric power, and signed a deal with Kenya for two thousand megawatts more; that will be realized after the completion of the Ethiopian renaissance dam. That East African power pool can actually reach up to Rwanda (Adhanom 2015:3).

\section{Provision of Security - Peacekeeping}

Perhaps a reflection of the unfinished business of nation-building in the region, the contested nature of national borders, and mutual distrust among countries in the region, much of the Horn of Africa's politics revolves around issues of conflict and security than economic integration or development. A good deal of the resources and activities of IGAD is devoted towards addressing conflicts, although the organizations name suggests it should focus on development. Therefore, it follows that Ethiopia's dominant role is expressed more in security than in economic affairs. In light of this, Ethiopia has framed its intervention in Somalia and containment of Eritrea not only as a parochial pursuit of the selfish interest of Ethiopia, but also protecting the region from threats to peace and security. According to the Ministry of Foreign Affairs,

Ethiopia's intervention in Somalia was successful in two ways: first, it weakened the ICC and paved the way to the Djibouti peace process [in 2008], and Second, it weakened an offensive first from the Islamic Courts Council and later from Al Shabab towards Ethiopia. These extremists with the support of the Eritrean government, that orchestrates activities of destabilization in the Horn of Africa, believed that nothing could stop them to create havoc in 
the region, though it became crystal clear that the measure by Ethiopia successfully thwarted the threat. (MOFA 2009).

Ethiopia's extensive role in peacekeeping also falls under the context of provision of goods related to peace and security. Peacekeeping Operations (PKOs) are an essential component of Ethiopian foreign policy. Ethiopia began to take part in UN PKOs in the mid-20 ${ }^{\text {th }}$ century, sending troops to Korea in 1951 and to the DRC in 1959. In 2010 the government opened the Ethiopian International Peacekeeping Training Center (EIPKTC) "a center intended to become a hub of international excellence for the training of Ethiopian officers and experts, alongside a minimum of 15-20 per cent of foreign students, representing significant competition for Kenya's International Peace Support Training Centre" (Le Gouriellec 2018).

Table 2. Ethiopian Peacekeeping Contributions

\begin{tabular}{|l|r|}
\hline \multicolumn{1}{|c|}{$\begin{array}{c}\text { Peacekeeping } \\
\text { Mission }\end{array}$} & \multicolumn{1}{c|}{$\begin{array}{c}\text { Number of } \\
\text { troops }\end{array}$} \\
\hline UNISFA ${ }^{44}$ & 3,997 \\
\hline UNAMID & 2,569 \\
\hline UNMIL & 13 \\
\hline UNMISS & 8 \\
\hline UNOCI & 2 \\
\hline AMISOM & 4,395 \\
\hline Total & $\mathbf{1 3 , 9 8 4}$ \\
\hline Source: Dersso $(2013)^{45}$, United Nations
\end{tabular}

\footnotetext{
${ }^{44}$ UNISFA forces are exclusively made up of Ethiopian troops including the force Commander.

${ }^{45}$ http://www.providingforpeacekeeping.org/2014/04/03/contributor-profile-ethiopia/

${ }^{46}$ http://www.un.org/en/peacekeeping/resources/statistics/contributors.shtml
} 
As table 2 shows, as of 2015 Ethiopia was the second largest contributor to UN peacekeeping missions, and the largest if AU missions are included. Although sending peacekeeping forces in and of itself is not necessarily a sign of regional dominance, Ethiopia has used it to advance its regional agenda. Some of the countries with high contribution like Bangladesh and Nepal, cannot be considered regional powers in their respective regions. Scott Firsing (identified a number of factors that help to explain the participation of African states in PKOs, among which the following apply in the case of Ethiopia: international pressure; the desire for international and regional status and influence; the desire for prestige and influence within the United Nations system; national security; political gain; economic profit; and the modernization or growth of the armed forces. First, it is a source of prestige and diplomatic support. Ethiopia frequently cites its active participation in peacekeeping as a sign of the country's internal stability and its ability and willingness to play a constructive role in the peace and security of the region. As Dessalegn Hailemariam, the former Prime Minister of Ethiopia, noted,

It gives us great is now the second largest contributor to UN Peacekeeping and I wish to take this opportunity to reaffirm our unwavering commitment to continue playing an active role to help ensure the United Nations becomes more effective and secure greater legitimacy. (Hailemariam 2016)

[t]he Ethiopian government has sent peacekeeping forces to Rwanda, Burundi and Liberia in a drive to restore peace and order in these countries thereby ensure and maintain the peace and security of the African continent. In addition to this, the peacekeeping forces Ethiopia has sent to different parts of Africa in the past years have been discharging effectively the peace-keeping responsibility entrusted to them. This has helped the nation to win popularity and full recognition of the global community. The Ethiopian peace keeping troops have won respect, trust and love among the peoples 
of those African countries, where they stayed and are staying, for the high discipline and ethics they had and have been demonstrating and for discharging effectively and efficiently the responsibility vested on them. This was the very reason for Ethiopia to be chosen by the international community to send its peacekeeping troops recently to Abiye province, which has been a source of conflict between the Sudan and South Sudan. This in return has helped Ethiopia to achieve an international acclaim while enabling the country to build trust and respect among the peoples in the sub-region, including the Sudanese and Somali people. Thus, it can be said that Ethiopia has laid a strong foundation for further enhancing and expanding its relations with the countries of the Horn of Africa. This success is also attributed to the country's sound Foreign Relations and National Security Policy and Strategy.

Second and more importantly, sending peacekeeping troops to conflicts in neighboring countries in which Ethiopia has a stake affords a unique opportunity to extend influence. This explains why some warring factions in Somalia strongly opposed the deployment of the front-line states as part of the AU peacekeeping mission in 2006. By 2013, the actors and interests in Somalia have changed enough to make the deployment of troops from the neighboring countries possible. Currently Kenya and Djibouti have peacekeeping troops in Somalia. Ethiopia formally joined AMISOM in 2014 although its troops returned to Somalia in 2011 to engage the al-Shabaab jointly with AMISOM and TFG forces. Currently Ethiopian peacekeepers are stationed in SW3 section of AMISOM, an area straddling Ogaden, the stage of much of Ethiopia's incursion into Somalia over the past two decades. Incorporation into AMISOM not only gives a semblance of legitimacy to Ethiopian presence inside Somalia, but also relieves the financial burden. Peacekeeping in neighboring states could also be used as a means of creating a buffer security zone and a sphere of influence. Kenya and Ethiopia, 
whose forces were engaged in fighting Al-Shabaab in the southeast and south east Somalia and who jointly contribute the most troops to AMISOM, provided the political impetus for the talks over the formation of regional administrations in Jubaland and Bay Bakool, the stability of which is considered vital to the security of Kenya and Ethiopia respectively. "The Kenyan government, in particular, viewed the formation of a stable Jubaland authority as the cornerstone of an exit strategy for its troops in Somalia" (Bryden 2013).

\section{Perception of regional leadership}

Regional powers stand out from other states in their respective region not only in their ability to successfully pursue their regional interests and project their image, but also the perception that they have of their regional role and that attributed by other actors both outside and inside the region. According to this viewpoint, the ambition and the willingness to take the lead is a necessary condition for a regional power. Thus, a logical step in analyzing Ethiopia's standing is to examine whether there are indications of a pretension to regional leadership on the part of the Ethiopian government and whether such pretensions are voiced by the political elite in Addis Ababa.

The question of perception in international and regional relations is closely tied to the conception of national roles in international politics. According to Holsti, "a national role conception includes the policymakers' own definitions of the general kinds of decisions, commitments, rules and actions suitable to their state, and of the functions, if any, their state should perform on a continuing basis in the 
international system or in subordinate regional systems. It is their "image" of the appropriate orientations or functions of their state toward, or in, the external environment." (Holsti 1970:245-246) Thus a state that assumes the role of a regional leader "perceives itself to have sufficient resources and capabilities to enable it to dominate a regional sphere," and the themes for such national role conception "refer to duties or special responsibilities that a government perceives for itself in its relation to states in a particular region with which it identified" (Holsti 1970:261)

Prys argues, however, that regional powers often adopt a 'strategy of denial' which might be necessary "to maintain the unstable equilibrium by avoiding the negative consequences of being seen as an imperialistic state." She adds that "Due to the negative impacts of being seen as a regional hegemon and the negative connotations attached to the concept of hegemony, predominantly by policy-makers, denial is an element of regional hegemonic behavior." It could be added that potential hegemons prefer the strategy of denial not only to avoid the jealousy it might invoke on the part of other actors but also for fear of being taken advantage of by free riders. Hegemonic systems are tightly linked with the unilateral provision of public goods by the hegemon such as trading systems, exchange rates, serving as a lender of last resort, and even incurring the costs to maintain regional order and stability.

The strategy of denial is thus "an empirically derived pattern, which is emphasized in various degrees by (potential) regional hegemons." Suspicion, hostility and jealousy particularly pervade regions such as the Horn of Africa with 
unsettled political borders and a history of interference in the internal affairs. In such cases the potential hegemon is even more inclined to assume a strategy of denial. Even South Africa, which dominates Southern Africa in terms of material capabilities and has a cosmopolitan constitution that openly espouses the dissemination of liberal democracy, often denies a pretension of regional dominance and leadership.

We can gather information on the self-perception of regional powers through various sources. First of all, actions that promote Ethiopia's own vision and values for the region through activities and initiatives at the bilateral and multilateral levels are partially dependent on the self-perception of Ethiopia (Prys 2012). The foregoing discussion of the influential role Ethiopia plays in regional politics is partially a manifestation of such self-perception. Second, official meetings, communiques, speeches and documents reveal a certain record of a country's ambition in a region. However, foreign policy decision making is shrouded in secrecy and finding sources that show the true intent of national leaders is difficult. Besides, as stipulated above when it comes to regional powerhood, political leaders prefer a strategy of denial not to arouse competition. Such strategy is definitely evinced in Ethiopia official tack of regional diplomacy. Seyoum Mesfin, who served as Ethiopia's Foreign Minister for two decades from 1991-2011 was recently asked whether he agreed with the assessment that "a number of scholars allude to the fact that Ethiopia has no choice but to play the role of a regional hegemony in the Horn of Africa. Having led the peace negotiations in one of Ethiopia's neighboring countries." In reply, Seyoum stated: 
you have to consider that these kinds of propositions are forwarded by people in academia and scholarly circles. But, you also have to know that it is their prerogative to make such assertions since they have no obligation to actually scrutinize such assertions and see if they are tested on the ground. However, it is true that, Ethiopia is a credible country with credible people and state. So, it cannot say that its responsibility starts and ends with its own. That is why, currently, Ethiopia stands second with regard to its contribution to the UN peacekeeping mission in Africa. We are not doing this because we have strong armed forces. It is because we have responsibilities...Ethiopia has more at stake than before since our development endeavor is invariably connected to the peace and security of the country and its immediate neighbors...we do wish that our neighboring nations find peace and security; so we do what we can to make sure that happens. However, we also want the peace and security for our own selfish reason since our security depends on them having peace and security. So, in that regard, we do understand our responsibility... with regard to hegemony, powerplay and the like, we believe that it is a failed model through which even countries like the US have not managed to bring peace to the world. The story is the same with the Europeans and their NATO instrument; we can see what their hand work [sic] has created in Libya...Afghanistan, Iraq and Syria. All these problems were created because the western powers believed that they were the policemen of the world and that they can bring democracy and freedom in other nations. So, to the case of Ethiopia, we have no dream of making this model work while the most powerful and affluent nations on the global scene had failed to do. Ethiopia is taking a different avenue; we are focusing on the cooperation angle both economically and politically. (emphasis added)

There are three elements to this lengthy statement. First, Mesfin accurately recognizes the assertion of Ethiopia's regional role is often raised by scholars. A reading of recent literature on Ethiopia's foreign relations demonstrates a growing number of scholarly works linking Ethiopia with the Horn of Africa region. A regional analyst Kjetil Tronvoll (2010) argues that Ethiopia is the regional hegemon, whether one likes it or not. It is the only state in with the capacity to project political and military force beyond its borders in a manner that is both stabilizing and 
threatening to its neighbors. In an overview of Ethiopia's interactions with countries

in the region, Tronvoll opines,

During the next several years... given continued economic advance, Ethiopia can endure as the Horn of Africa's central pillar of stability. Its ever-increasing role in the region will not be challenged by any other regional state or combination of states. It currently lies between two states, Sudan and Somalia, which were previously its two most formidable, largest and most populous neighbouring rivals. Currently, both states are simultaneously struggling to overcome decades of lethal conflicts and to adjust to territorial dismemberment. Ethiopia is also bordered by three states [Eritrea, South Sudan, Djibouti] which do not have the internal cohesion, the political organisation and the economic and military strength to effectively challenge its strategically critical role. Youngest and poorest South Sudan is grappling with its new national identity project vis-à-vis its northern neighbour. Djibouti is more economically dependent on Ethiopia than any other regional state and relies on extra-regional military forces for its security. Eritrea is already cornered by the folly of its own actions. Finally, Ethiopia has a consistently good working relationship with one state which has a traditionally inward focus and is more sensitive to Ethiopia's security concerns and even shares some of them, Kenya.

Second, Mesfin's understanding of a regional power is myopic and negative and fails to understand the nuances of powerhood and the positive roles that powerful countries can use regionally and globally. His views are influenced by the 'negative' connotation of hegemony wherein provision of public goods by the hegemon is mainly egotistic and learns from a cost/benefit calculation and the realization of its interests through the establishment of a regional order. Acting as the 'policemen of the neighborhood' is only one-way regional power manifests, and there are other typologies depending on the manner in which regional dominance manifests. Such a view undervalues the conceptualization of regional powers as 
states pursuing benevolent, leading, integrative strategies. It is such nuanced and diverse sets of foreign policy strategies adopted by regional powers that most authors refer to in developing typologies of regional dominance (Destradi 2010; Prys 2010)

And third, his statement belies empirically observed behavior, and official and unofficial statements uttered by government officials and different party and government documents. The rise of Ethiopia as a regional powerhouse were originally uttered by a senior political advisor for the foreign ministry Kinfe Abraham in the aftermath of Ethiopia's military victory over Eritrea in 2000. In an article entitled A Regional Power, the UN news service IRIN reported that Abraham "said that Ethiopia had emerged as a defining power in the Horn of Africa region...Ethiopia held a responsibility to help maintain peace in the sub-region, and had a 'track record of not being aggressive, but responding decisively' [Moreover] He compared Ethiopia's 'super power' position in the region to that of Egypt in North Africa and Nigeria in West Africa." (emphasis added) Mesfin also averred in 2007 that "Ethiopia has been transformed into a leading regional and continental power that has ensured its national security interests with a growing role in the international arena". Commenting on the reference of the international media to Ethiopia as the super power of the Horn, Mesfin said "the country's geographical and demographic ties with all countries of the Horn, coupled with its population size, among other factors, gives it a strategic leading role in regional and continental matters. Ethiopia has therefore to fully utilize these potentials of 
commonalities it shares with countries of the Horn to ensure the regional socioeconomic and political integration..." (BBC 2007).

Party documents also reveal the ruling party and the government is fully cognizant of the increasingly important role it plays in the region. A party publication states that

the multi-dimensional political and social initiatives we undertook in the last 20 years to ensure the renaissance of our country have gone beyond our country and are influencing our neighbors and other African countries. Many African countries are emulating and copying our achievements, victories successes we achieved through our developmental state policies and directions...multiple works undertaken to bring together link with neighboring countries through energy, railways, road and telecom and other infrastructure not only enforce strengthen regional integration. The developmental democratic mentality ideology that is the source of all these activities efforts is replicated and adopted by neighboring and other African states. Although the activities are carried out primarily with the aim of ensuring Ethiopia's renaissance, they play their own role in the struggle and effort to ensure Africa's renaissance couples with other constructive efforts undertakings... However, we should not embark on a campaign to impose our influence on other countries [which is] neither correct/right nor does it concur with the spirit of African brotherhood/solidarity we pursue (New Vision)

In an Ethiopian millennium special edition, the party document demonstrated a deeper awareness of Ethiopia's regional role by comparing it with Germany's role in Europe.

The role Ethiopia can and should play in the Horn of Africa is in many ways similar to the role Germany played in post-world war two Europe...the new Ethiopia that has started taking strides steps by linking democracy and development can play the constructive role that the new Germany played in the post war growth and unification of Europe. Just as Germany's growth has driven Europe's economy, Ethiopia's economic growth can drive the economy of the Horn of Africa. Just as Germany's democratic change fostered amity among Europeans and laid the foundation for the unification of Europe, Ethiopia's democratic development can also promote harmony in the 
Horn of Africa, and can be the engine for the integration of the Horn of Africa and also contribute to the strengthening of the African unity (New Vision).

\section{Chapter conclusion}

Chapters 2 and 3 aimed to substantiate the argument that Ethiopia has emerged as a regional power in the Horn of Africa sub-region. Chapter 2 focused on bilateral interactions between Ethiopia and Somalia and Eritrea to demonstrate a growing influence of Ethiopia both in war and peace. Chapter 3 used the three p's projection of interest, provision of public goods and perception as regional power - framework developed by Prys (2010) to reinforce the argument that Ethiopia has become a key regional power.

With regards to projection of power regionally, the 2002 foreign and security policy stipulates that Ethiopia's key interest in Somalia has been to prevent the rise of an Islamic regime or one that would revive the long-lasting ambition of Somalia irredentism. In addition, Ethiopia sought to ensure Somalia will not become a haven for rebel armies that threaten the security of the regime in Addis. Ethiopia also sought to export a federal arrangement along clan lines similar to the ethnic federal system Ethiopia adopted in 1995. Although the objectives have more or less been met. Success has been qualified. After the military intervention in 2006, the Ethiopian forces were bogged down in years of urban warfare that proved to be costly. The defeat of the UIC only led to the rise of an even more radicalized al-

Shabaab. As regards to Eritrea, Ethiopia's immediate interest after the 1998 war erupted was the regain territories taken by the Eritrean military. The military victory in 2000 secured this objective. Afterwards, Ethiopia had isolated Eritrea to ensure 
it will not become a menace in the region. Eritrea continued its open support to Ethiopian insurgent groups in Somalia. The tripartite agreement with Sudan and Yemen and IGAD's unqualified support to Ethiopia's military intervention in Somalia was a key diplomatic success for Ethiopia.

Regional powers also provide public goods in their region mainly in the form of economic and security or military support. Economically, Ethiopia is not in the position to act as a source of region-wide economic benefits. In terms of GDP, the next chapter will show that its share in the region is roughly equal to Kenya and Sudan. It cannot act as a lender of last resort nor through granting favored access to its market. As the next chapter shows, economic integration in terms of trade and investment in the region is weak. Ethiopia cannot use access to or denial of trade and market as leverage in its dealings with regional countries. Ethiopia's economic clout thus emanates from potential and ambition to be a regional energy hub. To that effect, Ethiopia has undertaken a series of giant infrastructural projects the conclusion of which it hopes will foster regional economic integration. In particular, Ethiopia aims to produce and export cheap electricity; the intent is strategic and political as much as economic and financial. Ethiopia has been far more successful in active partaking in UN PKOs. As a major contributor to PKOs, Ethiopia gained diplomatic prestige and support and political and strategic presence in neighboring countries Sudan and Somalia. 
The third element of the three p's is perception. Prys argues that government leaders often have a strategy of denial as regional hegemon. This is exhibited by Ethiopian leaders as well. However, I have shown that various interviews by the political leaders and party documents demonstrate a growing appreciation of Ethiopia's role in the region. Empirically, observable actions by Ethiopia (in Somalia, peacekeeping and active diplomacy) also suggest such selfperception. 


\section{Analysis of the Distribution of Material Capabilities}

Attributional capability, power derived from the control of resources, is a fundamental disposition that tends to give an actor control over outcomes. Thus, regional powers are states "with relative preponderance in a given geographical region [that] can make crucial contributions to the construction and deconstruction of regional orders and, thereby, to international peace and stability as well through their material resources" (Prys 2010:485; emphasis added). Capabilities as objective aspects of national power are used to assess the ability of nations to influence others, and the balance of such capabilities between two states or a group of states is a sound indicator of their relative influence (Kugler and Arbetman 1989:50). In other words, a state is powerful compared with its peers in the sense of attributional capabilities if it has a large amount of economic, political, military, demographic resources for use.

The assessment of the distribution of capabilities to determine the number of poles of an international system is a central concern of neorealism. Neorealism assumes that states are engaged in a perpetual competition for security in an anarchic inter-state system. In such competition, states will achieve varying and unequal degrees of capability. Whereas the functions of the constitutive units of the system is essentially the same, the capabilities that underlie their ability to perform these functions are distributed differently. Kenneth Waltz (1979:96) claims that "states are alike in the tasks that they face, though not in their abilities to perform them". An assessment of such mixed diffusion of capabilities across the 
units at any given time determines the structure of polarity at the global and, by extension, at the regional levels. Although Waltz's developed his analysis at the global level, the logic of hierarchies of power as derived from capabilities is applicable to the regional level. However, whereas the global is a closed system, the regional is an open one and regional powers are affected by extra regional and/or global powers.

Unipolarity or the existence of a dominant power globally or, pertinent to our case, in a specific region prevails when a single state in the system is markedly superior relative to all other states in terms of demographic, economic, and military resources ${ }^{47}$ Bipolarity prevails when two states are roughly equal along these attributes, and so on. Therefore, the fundamental empirical prediction is that the relative amount of material power resources at the disposal of individual countries over the long term will shape the magnitude and ambition of their foreign policies. States seek more influence in their region and beyond as their relative power rises, and they scale back their actions and ambitions accordingly as their relative power declines. The same logic applies to the sub regional system of states.

This chapter analyzes the attributional capabilities of Ethiopia in relation to countries of the Horn of Africa to investigate whether Ethiopia's rising influence can be explained by changes in its material capabilities relative to other states in the region. The chapter briefly discusses the elements of national power using demographic, economic and military capabilities to assess the distribution of

\footnotetext{
47 "A hierarchical regional system may be defined as a regional international system composed of a single Great Power and a number of relatively small states" (Zimmerman 1972:18).
} 
material capacities in the region. While relative power is undoubtedly a central variable in understanding state behavior, its measurement remains contested. Analysts continuously debate the components that should be utilized when calculating power capabilities, and how those components can best be aggregated into a single measurement of power. Most measures of so-called 'hard power' tend to emphasize three primary components of power capability: economic, demographic, and military strength. ${ }^{48}$ Although additional dimensions of power have subsequently been considered to refine the original broad measures including measures of wealth, trade, aid and investment flows; technological capabilities; and government capacity and human capital - in the regional power literature, "most available power indices rely on a combination of measures including the Gross National Product (GNP), at times supplemented with demographic and military measures" (Prys 2010:486; See also Lemke 2008 and Nolte 2007) The following table summarizes some of the preferred variables in the regional powers literature.

\footnotetext{
48 Hans Morgenthau's elements of national power are divided into 'stable' and 'changing' and comprise geography, natural resources (food, raw materials), industrial capacity, military preparedness (technology, leadership, quantity and quality of armed forces), population (distribution, trends), national character, national morale, quality of society and government, and quality of diplomacy and quality of government (Morgenthau 1948, 1954) Waltz also points out that the power ranking of states depends on how they score on size of population and territory, resource endowment, economic capability, military strength, political stability and competence (Waltz 1979:131). He argues that the economic, military, and other capabilities of nations cannot be sectored and separately weighed. States are not placed in the top rank because they excel in one way or another.
} 
Table 3. Summary of Capability Variables by Various Authors

\begin{tabular}{|c|c|c|c|c|}
\hline Indicators & $\begin{array}{c}\text { Godenhardt } \\
\text { and Nabers } \\
\text { (2011) }\end{array}$ & $\begin{array}{l}\text { Ingersoll and } \\
\text { Fraiser (2012) }\end{array}$ & Lemke (2002) & $\begin{array}{l}\text { Cline et al } \\
(2011)\end{array}$ \\
\hline Economic & - GNP & $\begin{array}{l}\text { - GDP } \\
\text { - GDP/Capita } \\
\text { - national } \\
\text { energy } \\
\text { consumption }\end{array}$ & $\begin{array}{l}\text { - } \text { national } \\
\text { energy } \\
\text { consumption } \\
\text { - iron/steel } \\
\text { production } \\
\text { - GDP/GNP } \\
\end{array}$ & $\begin{array}{l}\text { - Market } \\
\text { capitalization } \\
\text { of domestic } \\
\text { firms }\end{array}$ \\
\hline Military & $\begin{array}{l}\text { - Military } \\
\text { expenditure }\end{array}$ & $\begin{array}{l}\text { - military } \\
\text { personnel } \\
\text { - military } \\
\text { expenditure } \\
\text { - military } \\
\text { spending as } \\
\text { a proportion } \\
\text { of GDP }\end{array}$ & $\begin{array}{l}\text { - } \text { military } \\
\text { personnel } \\
\text { - military } \\
\text { expenditure }\end{array}$ & $\begin{array}{l}\text { - military } \\
\text { personnel } \\
\text { - military } \\
\text { expenditure }\end{array}$ \\
\hline Demographic & - population & $\begin{array}{l}\text { - relative } \\
\text { population } \\
\text { size } \\
\text { - nominal total } \\
\text { population } \\
\text { - nominal } \\
\text { urban } \\
\text { population }\end{array}$ & $\begin{array}{l}\text { - nominal } \\
\text { urban } \\
\text { population } \\
\text { - nominal total } \\
\text { population }\end{array}$ & \\
\hline
\end{tabular}

A thorough analysis of the power distribution of all countries of the Horn for an extended period is beyond the scope of this study. Such a project necessitates an examination of additional indicators than are included here many of which require complex analyses in their own right. An analysis of the military component alone would comprise consideration of military doctrine, force structure and leadership and technological sophistication. This chapter focuses on holistic patterns of changes in the population, economy and military dimensions of national power in the belief that a generalized probe of these capabilities provides a sound 
understanding of the structure of polarity in the Horn of Africa. As table 3 above demonstrates, population, economy (GDP) and military (expenditure and personnel) are the oft-used indicators of material capability.

\section{Population and Physical size}

Countries often regarded as regional great powers - for example Brazil, China, India, and Russia - all have one feature in common: the physical size or scope of their territory (Brazil, Russia) and the number of their inhabitants (China, India). Likewise, states in Africa commonly believed to be actual or prospective regional powers - Nigeria, Ethiopia, Egypt, DRC, and South Africa ${ }^{49}$ - are also the five most populous countries not just in their respective sub-regions but at the continental level (UNECA 2016). Therefore, although not an automatic guarantee of leadership, a large population is a fundamental prerequisite of regional power status $^{50}$ and is often taken as a major pointer of the potential and actual power capability of a country (Ingersoll 2012; Flemes and Nolte 2010).

A large population affords a stock of labor for resource utilization and industrialization, and it provides potential market for domestic or foreign goods and services. Often referred to as the human capital of a country, evaluation of the size

\footnotetext{
${ }^{49}$ All these countries except Egypt appear in the list of potential regional hegemons in Sub Saharan Africa in Herbst (2000). Clapham et al (2006) also incorporate these countries - with the addition of Angola and Sudan - in their discussion of Africa's big states.

50 In appreciation of the value of large population both to an economy and military segments of a country, Morgenthau states "without a large population, it is impossible to establish and keep going the industrial plant necessary for the successful conduct of modern war; to put into field the large number of combat groups to fight...and finally to fill the cadre of the troops, considerably more numerous than the combat troops, which must supply the latter with food, means of transportation and communication, ammunition and weapons" (1960:122)
} 
and quality of a country's population and has gained momentum in the face of growing importance of economic power. Hence, "population is the sine qua non for great power status...[and] it is the potential resource to pool that a nation can begin to mobilize through economic development" (Ingersoll quoting Tammen et al 2012:54). The health, education level, and degree of "national adhesion" of the population are some of the variables that contribute to the human capital of a population.

In addition to its economic potentialities, a sizable population can provide a large pool of human resources for mobilization for war. Notably, a country with a sizeable population can raise a large army. Per Mearsheimer (2001:61), "population size matters a lot because great powers require big armies, which can be raised only in countries with large populations." Nichiprouk concurs that "differences between rate in population growth rate or size can change the existing conventional military balance of power". Corroborating this argument, Djuvanovic (2008:2) argues "...the variance in population size amongst members of the international system is so large that it dwarfs any regime related advantages... when waging an international war population size is a country's most valuable asset by far". Large populations can also support wars through support activities such as growing and preparing food, producing arms and the like.

Table 4 and Chart 1 present the geographic size and population distribution in the Horn of Africa. In terms of physical size, the Horn of Africa is home to two of the largest countries in Africa - Sudan and Ethiopia. Even after the loss of significant territory after the independence of South Sudan and Eritrea 
respectively, Sudan and Ethiopia remain the third and tenth largest countries in Africa. In terms of demographic indictors such as urban population ${ }^{51}$, dependency ratio and the share of productive age population, there is a marked similarity between the two countries. Therefore, any advantage gained from demography would come from the overall size of the population. Ethiopia is the clear leader with regards to total population implying that it has latent, long-term potential to be a regional power if it remains stable and relatively powerful across other indicators. Ethiopia accounts for 40 percent of the population in the region, more than double that of the next most populous country - Kenya - and more than the two next biggest countries - Kenya and Sudan - combined. Due to their economic and military clout, Kenya and Sudan are the other possible sub-regional hegemons.

Table 4. Demographic Indicators - Horn of Africa (2015)

\begin{tabular}{|l|r|r|r|r|r|}
\hline \multicolumn{1}{|c|}{ Country } & $\begin{array}{c}\text { Total } \\
\text { Population } \\
\text { (in millions) }\end{array}$ & $\begin{array}{c}\text { Productive } \\
\text { Age (15- } \\
\text { 64) as \% } \\
\text { of total }\end{array}$ & $\begin{array}{c}\text { Total } \\
\text { Dependency } \\
\text { Ratio52 }\end{array}$ & $\begin{array}{c}\text { Urban } \\
\text { population } \\
\text { as \% of } \\
\text { total }\end{array}$ & $\begin{array}{c}\text { Area in } \\
\text { 000 Sq. } \\
\text { KM }\end{array}$ \\
\hline Djibouti & 0.9 & 63.1 & 58.5 & 77.3 & 23.18 \\
\hline Eritrea & 5.2 & 54.5 & 83.2 & 22.6 & 101 \\
\hline Ethiopia & 99.4 & 55.1 & 81.6 & 19.5 & 1000 \\
\hline Kenya & 46.1 & 55.3 & 80.9 & 25.6 & 569 \\
\hline Sudan & 40.2 & 56.2 & 78.0 & 33.8 & 1861 \\
\hline Somalia & 10.8 & 50.5 & 98.1 & 39.6 & 627 \\
\hline South Sudan & 12.3 & 54.4 & 83.7 & 18.8 & 644.3 \\
\hline Uganda & 39.0 & 49.4 & 102.3 & 16.1 & 200 \\
\hline Total & 254.40 & -- & -- & -- & -- \\
\hline
\end{tabular}

Source: World Bank (2016); UNECA (2016)

${ }^{51}$ Djibouti is an outlier in terms of rural-urban distribution, which can be explained by its small geographic size and the concentration of its population in the capital city.

52 Dependency Ratio estimates the population aged 0-14 and 65+ per 100 population 15-64. 


\section{Chart 1. Comparison of Population Size of the Countries of the Horn of Africa}

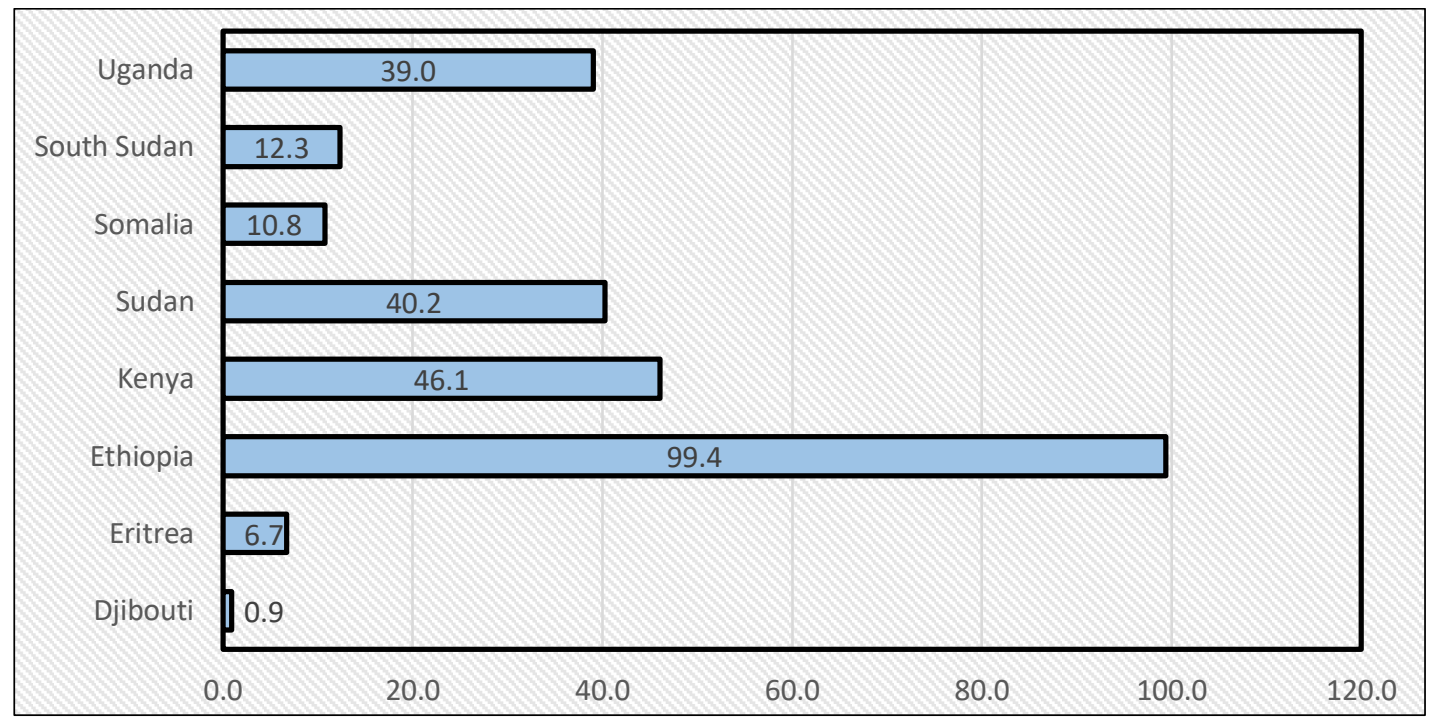

Source: World Bank (2016); UNECA (2016)

The significance of Ethiopia's population to its military capability is evident in its bilateral relations with Eritrea. A latter section of this chapter shows that Eritrea has roughly double the number of military personnel as Ethiopia. However, due to its small population, around 8 percent of Eritrea's total labor force serves in the military $^{53}$ (World Bank 2016), ranking second globally in the share of military personnel to total population (Warner 2013:701). Eritrea has relied on conscription in view of its need to maintain large army in the face of hostilities with virtually all its neighbors. "Beginning in 1994, [Eritrea's President] Afewerki began a program of mandatory national service for all the country's citizens, demanding that all

\footnotetext{
${ }^{53}$ To put this number in perspective, "to mobilize $10 \%$ of the population for military services is an enormous undertaking...In the World War One, great European powers called $14 \%$ of their population to arms and in World War Two the figure exceeded $10 \%$ probably for the US, USSR and Germany" (Morgenthau 1960:371).
} 
Eritreans (both male and female) between the ages of 18 and 40 serve the country for at least 16 months, of which at least four are in military training. Age limits for service have been constantly expanding though, as in 2005, the Afewerki regime went to smaller Eritrean towns to recruit older males, aged 40 to 60 , for weeks of additional civil defense training" (Warner 2013:703). This has contributed to low morale, mass desertions, blurring of civil-military lines, and general unprofessionalism in of the Eritrean army, although Eritrea was not totally defeated (Idid.).

\section{National Economies}

Power understood in material terms highlights economic elements such as natural resources endowment, possession of capital, control over a large internal market and advantageous positioning in the production of high-value commodities (Keohane, cited in Prys 2010:20). Possession of these key resources enables a regional power to exercise economic leadership and provide public goods by promoting an open trading systems, acting as an outlet for troubled goods, sustaining the flow of capital, serving as lender of a last resort, ensuring stable exchange rates as well as coordinating macro-economic policies. Control of a sizable quantity of material wealth at the very least increases the prospect that certain actors exert leverage over others. Economic leverage of a state can be used as a means of employing power as well as using its economic resources to invest in military and other power capabilities (Ingersoll 2012:54-55). A nation cannot engage in conflict over an extended period without a strong economic base 
or some form of adjustment to its economy. Therefore, a basic understanding of the scope of the nation's economic power will help grasp how the country can use it along with other elements of power - political, military, and demographic. In the words of Mearsheimer

Although material resources alone do not decide the outcome of wars, there is no question that the odds of success are substantially affected by the balance of resources, especially in protracted wars of attrition in which each side is trying to wear down the other by virtue of material superiority... wealth is important because a state cannot build a powerful military if it does not have the money and technology to equip, train, and continually modernize its fighting force. (Mearsheimer 2001:58 and 61)

Table 5. Selected Economic Indicators - Horn of Africa (2015)

\begin{tabular}{|l|r|r|r|r|r|}
\hline \multirow{2}{*}{ Country } & \multicolumn{2}{|c|}{ Economic sectors (share of GDP) } & \multicolumn{2}{c|}{$\mathrm{HDI}^{\star}$} \\
\cline { 2 - 6 } & Agriculture & Industry & Services & \multicolumn{1}{c|}{ Value } & \multicolumn{1}{c|}{ Rank } \\
\hline Djibouti & $3.1^{*}$ & $21.2^{*}$ & 75.5 & 0.470 & 168 \\
\hline Eritrea & $12.5^{*}$ & $27.5^{*}$ & 60.0 & 0.391 & 186 \\
\hline Ethiopia & 41.0 & 16.3 & 42.7 & 0.442 & 174 \\
\hline Kenya & 32.9 & 19.5 & 47.6 & 0.548 & 145 \\
\hline Somalia & $60.2^{*}$ & $7.4^{*}$ & 32.4 & -- & -- \\
\hline South Sudan & -- & -- & -- & 0.467 & 174 \\
\hline Sudan & 28.6 & 20.5 & 49.9 & 0.479 & 167 \\
\hline Uganda & 24.7 & 20.4 & 54.9 & 0.470 & 168 \\
\hline
\end{tabular}

Source: World Bank (2016)

- Data obtained from UNDP (2015)

* Data obtained from CIA: The World Factbook (2016)

+2009 Est.

${ }^{++} 2013$ Est.

A cursory examination of selected socio-economic indicators in the Horn of Africa presented in table 5 display two attributes. First, the national economies are characterized by a degree of similarity. The share of industrial sector in general, and that of manufacturing in particular is low in common with most developing 
economies. Second, a comparison of the conditions of the national economies also denotes that these nations are among the poorest in the world. They are afflicted by social deprivation, and natural and man-made emergencies are regular occurrences. They are at the tail-end of human development measured in income inequality, child mortality, malnourishment, gender equality, access to education and the like. According to the 2015 UNDP Human Development Report, all states fall in the low human development group with an HDI of 0.550 and below. A comparison among countries reveals Kenya has the best HDI score. There is a 22 places difference with the next highest-ranking country (Sudan).

Despite the uniformity of the state of the region's economy, there are discernable differences among individual countries. Table 6 compares the regional states' GDP over a period of ten years (2006-2015). Among the various indicators of the state of a nation's economy, GDP or a state's entire output for one year provides the best snapshot of a nation's overall economic performance and the economic strength that a given country has relative to the rest of the region. In fact, for states at a similar level of economic development and at low level of industrialization, GDP is a sound indicator of a disparities in wealth and power (Mearsheimer 2001:62-63). 
Table 6. Total GDP-PPP - Horn of Africa ${ }^{54}$ (in billions USD 2015 value)

\begin{tabular}{|c|c|c|c|c|c|c|c|c|c|c|}
\hline & 2006 & 2007 & 2008 & 2009 & 2010 & 2011 & 2012 & 2013 & 2014 & 2015 \\
\hline Djibouti & 1.7 & 1.8 & 2.0 & 2.0 & 2.1 & 2.3 & 2.5 & 2.7 & 2.9 & 3.1 \\
\hline Eritrea & 5.9 & 6.1 & 5.6 & 5.9 & 6.1 & 6.8 & 7.4 & 7.7 & 8.2 & 8.7 \\
\hline Ethiopia & 57.0 & 65.5 & 74.2 & 82.3 & 92.1 & 104.7 & 115.9 & 129.5 & 145.2 & 161.6 \\
\hline Kenya & 78.3 & 85.9 & 87.8 & 91.4 & 100.3 & 108.6 & 115.7 & 124.2 & 133.0 & 141.9 \\
\hline $\begin{array}{l}\text { South } \\
\text { Sudan }\end{array}$ & - & - & - & - & - & 35.3 & 17.1 & 22.5 & 23.5 & 23.7 \\
\hline Sudan & 112.9 & 125.8 & 132.1 & 139.4 & 145.3 & 146.5 & 144.1 & 152.2 & 159.7 & 167.0 \\
\hline Uganda & 39.5 & 43.9 & 49.4 & 53.8 & 58.6 & 63.9 & 66.8 & 70.6 & 75.3 & 79.9 \\
\hline Total & 295.4 & 329 & 351.2 & 374.8 & 404.6 & 468.1 & 469.4 & 509.4 & 547.8 & 585.8 \\
\hline
\end{tabular}

Source: IMF (2017)

According to table 6 and chart 2, the three economic heavyweights in the region are Sudan, Ethiopia, and Kenya (table 6) accounting for 80 percent of the region's GDP in 2015. However, there is no clear pattern of leadership across these states along the dimension of economic capabilities. By one measure, Sudan has the largest economy with a GDP of $\$ 167.0$ billion. Ethiopia and Kenya closely follow with GDPs of $\$ 161.6$ billion and $\$ 141.9$ billion, respectively. There is a yawning chasm between these three large-economy countries (Sudan, Ethiopia, Sudan) and low GDP countries (South Sudan, Eritrea, Djibouti) with Uganda resting in the middle at $\$ 79.9$ billion.

\footnotetext{
${ }^{54}$ Data for Somalia not available.
} 
Chart .2 The GDP Share of IGAD member Countries (2015)

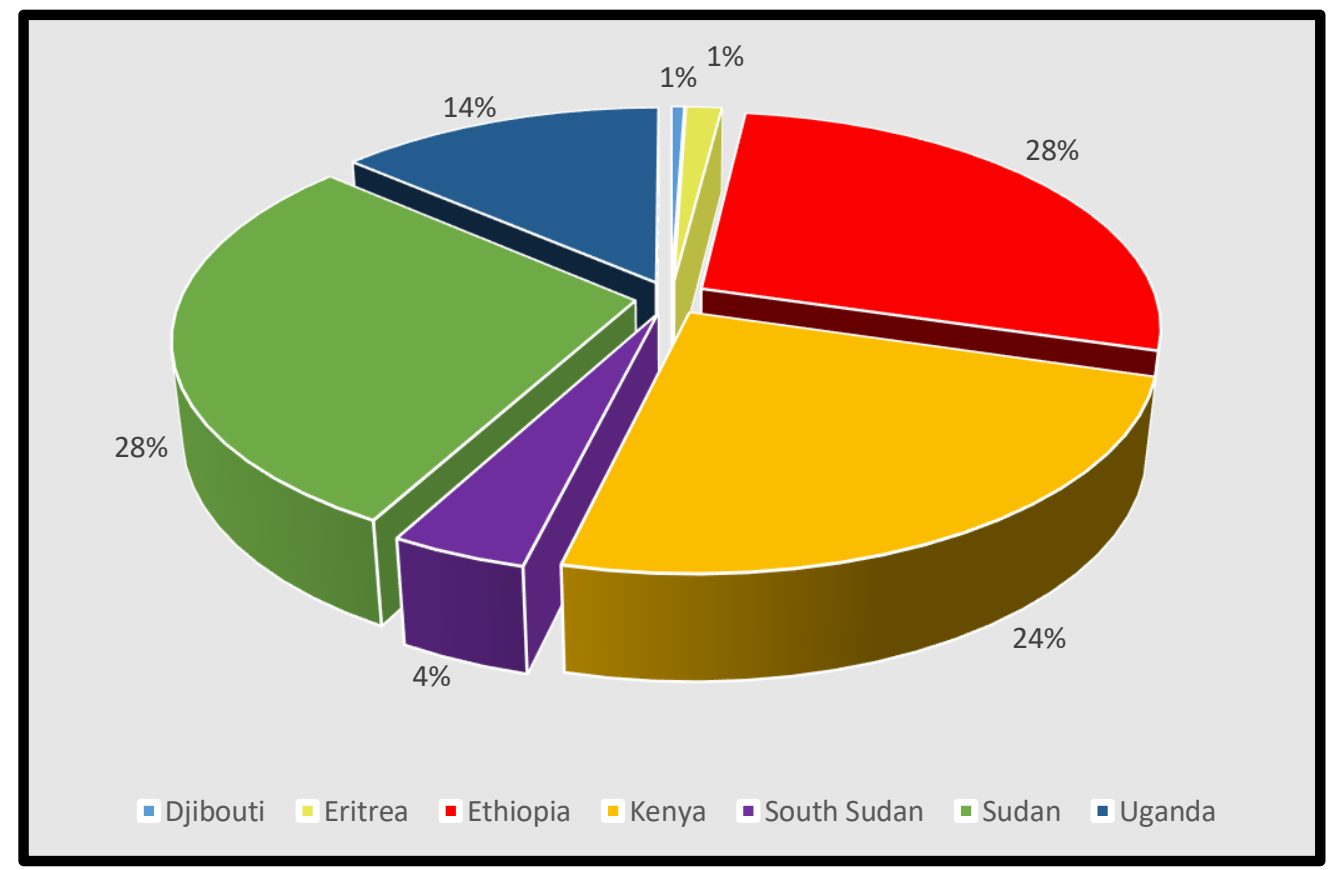

However, the observation of economic strength arising from GDP should consider several caveats. First, even though Sudan currently has the biggest GDP in the region, its economy is heavily reliant on the extraction and export of fossil fuels contributing for over half of government revenues and 95 percent of export earnings (World Bank 2016). Fluctuations in the international price for oil and the recent decline in the global price of oil has adversely affected the growth rate of Sudan's economy. The loss of oil rich territories to South Sudan after the 2011 referendum - which accounted for three quarters of Sudan's oil export (CIA 2016) - has also affected Sudan's economy. Ethiopia's and Kenya's economies are more diversified than Sudan's and are likely to weather international shocks. 
Table 7. GDP Growth Rate (2006 - 2015) - Horn of Africa ${ }^{55}$

\begin{tabular}{|c|c|c|c|c|c|c|c|c|c|c|c|}
\hline Country & 06 & 07 & 08 & 09 & 10 & 11 & 12 & 13 & 14 & 15 & Ave. \\
\hline Djibouti & 4.8 & 5.0 & 5.8 & 1.6 & 4.1 & 7.3 & 4.8 & 5.0 & 6.0 & 6.5 & 5.1 \\
\hline Eritrea & -1.0 & 1.4 & -9.8 & 3.9 & 2.2 & 8.7 & 7.0 & 3.1 & 5.0 & 4.8 & 2.5 \\
\hline Ethiopia & 11.5 & 11.8 & 11.2 & 10 & 10.6 & 11.4 & 8.7 & 9.9 & 10.3 & 10.2 & 10.6 \\
\hline Kenya & 5.9 & 6.9 & 0.2 & 3.3 & 8.4 & 6.1 & 4.6 & 5.7 & 5.3 & 5.6 & 5.2 \\
\hline $\begin{array}{l}\text { South } \\
\text { Sudan }\end{array}$ & & & & - & - & $n / a$ & -52.4 & 29.3 & 2.9 & -0.2 & -5.1 \\
\hline Sudan & 8.9 & 8.5 & 3.0 & 4.7 & 3.0 & -1.3 & -3.4 & 3.9 & 3.3 & 3.5 & 3.4 \\
\hline Uganda & 7.0 & 8.1 & 10.4 & 8.1 & 7.7 & 6.8 & 2.6 & 4.0 & 4.9 & 5.0 & 6.5 \\
\hline
\end{tabular}

Source: IMF (2017)

Chart 3. GDP-PPP Growth Trends - Horn of Africa

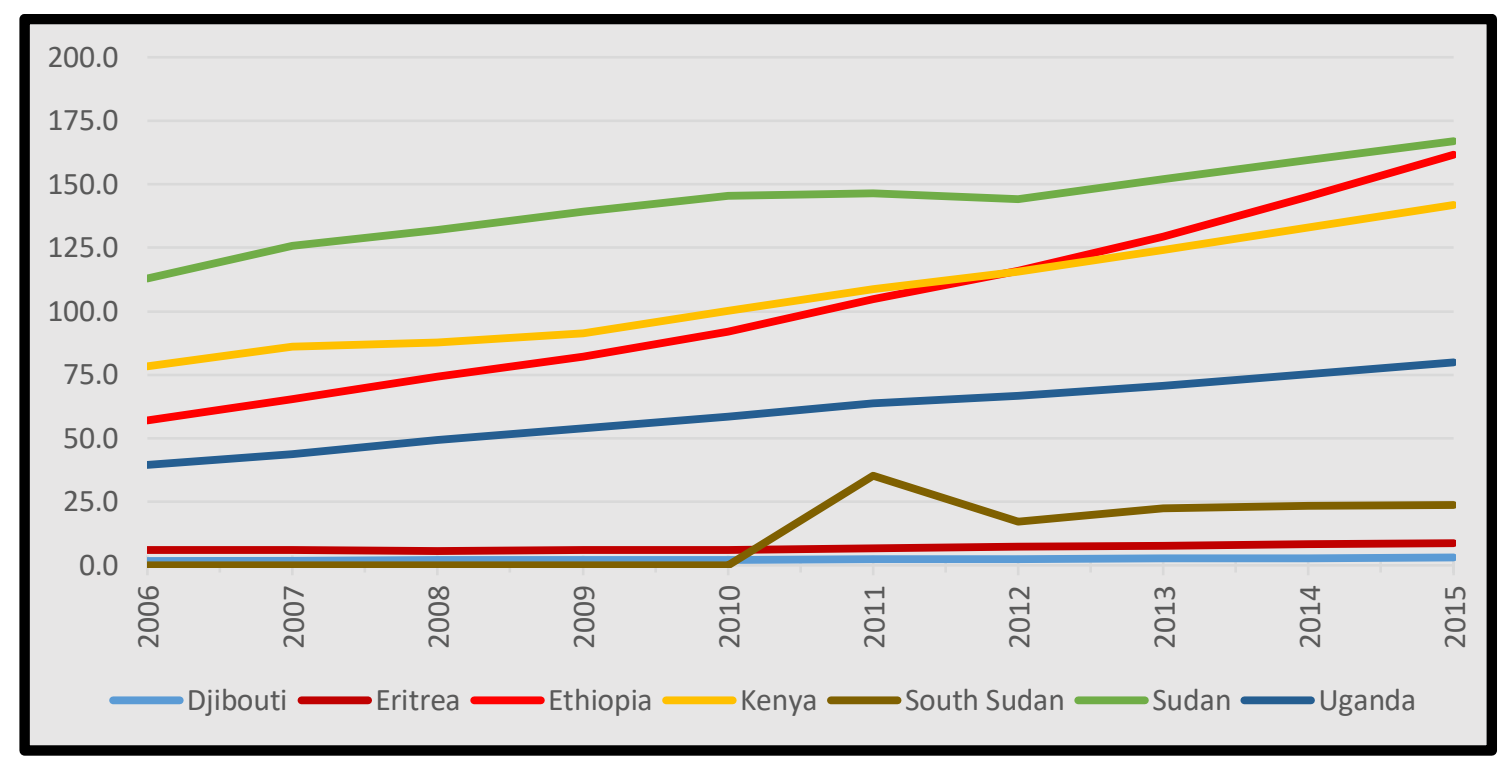

The second caveat relates to differences in the rate of GDP growth in the region.

The African Development Bank states that the East African region has the fastest rate of economic growth of all the regions of Africa with Ethiopia, Kenya, Djibouti and Uganda all registering impressively high rates of growth of GDP (AfDB 2016).

55 Data for Somalia not available. 
It is evident from table 7 and chart 3 that Ethiopia has recorded the highest rates of economic growth effectively tripling its GDP within the last decade; what might be called Ethiopia's "great leap forward" (Le Gouriellec 2018:1024). The Ethiopian economy has enjoyed an average GDP growth over 10 percent in the past decade, compared to a 5.4 percent average throughout sub-Saharan Africa. Sustaining such high record of economic growth reflects faster rates of convergence and eventual economic dominance for Ethiopia, which overtook Kenya as the second largest economy in the region in 2012 and which is forecasted by the IMF to become the largest economy in the region by 2021 (table 8 ).

Table 8. Six Years GDP Forecast - Horn of Africa

\begin{tabular}{|l|r|r|r|r|r|r|}
\hline Country & $\mathbf{2 0 1 6}$ & $\mathbf{2 0 1 7}$ & $\mathbf{2 0 1 8}$ & $\mathbf{2 0 1 9}$ & $\mathbf{2 0 2 0}$ & $\mathbf{2 0 2 1}$ \\
\hline Djibouti & 3.3 & 3.6 & 3.9 & 4.3 & 4.7 & 5.0 \\
\hline Eritrea & 9.1 & 9.5 & 10.1 & 10.7 & 11.3 & 12.0 \\
\hline Ethiopia & 170.5 & 184.9 & 202.8 & 222.8 & 244.6 & 267.9 \\
\hline Kenya & 151.8 & 163.4 & 177.4 & 193.0 & 209.8 & 228.0 \\
\hline South Sudan & 22.1 & 24.2 & 26.5 & 29.9 & 33.1 & 34.0 \\
\hline Sudan & 174.9 & 184.3 & 195.5 & 207.8 & 220.7 & 234.4 \\
\hline Uganda & 84.9 & 91.0 & 98.3 & 106.5 & 115.6 & 125.6 \\
\hline
\end{tabular}

Source: IMF (2017)

By 2021 Ethiopia would be the region's economic leader. These forecasts are echoed by other researchers of relative power capability in Africa. An extended study of the projection of power capabilities of five key states in Africa claimed that

although Ethiopia's GDP was 12 times smaller than that of Nigeria in 2014 , at the end of the forecast period in question [2040] it is estimated that Ethiopia will be the sixth largest economy in [all of] Africa and only eight times smaller than that of Nigeria...for the period 2015 to $2040 \ldots$... Ethiopia is expected to achieve the highest 
average growth rate of the Big Five F $^{56}$ on average, almost $2 \%$ faster than the $8.3 \%$ of Nigeria. whereas Algeria, Egypt and South Africa are expected to grow below the African average rate of $6.3 \%$, and roughly in line with the global average, Nigeria and Ethiopia are both expected to grow much faster. (Cilliers et al 2015:15)

Whereas GDP provides a partial picture of the economic strength of a state, an alternative means of gauging economic influence is to evaluate economic interactions through trade. This illustrates the level of interdependence of a region's economies with the aim of assessing the significances of individual markets to the goods and services from other states. States can use economic clout that originates from trade and dependency for economic statecraft including boycott, preferential treatments, cutting-off trade, economic sanctions, economic dependency, embargoes and the like. These are elements of economic leverage or coercion that can be used as elements of regional foreign policies. However, their effectiveness is predicated on a well interlinked regional economy enabling a state to use economic statecraft as a source of leverage. Economic hierarchy as implied by trade dependence has long been understood to create the potential for political influence. "If a state has many trade partners it is likely to have greater political autonomy and any attempt to manipulate trade for political purposes will be ineffective. If a country is highly dependent on trade with another, however, it is vulnerable to the influence of that state" (Lake 2009:46).

The pattern of trade between IGAD members reveals that only fifteen percent of their international trade has been intragroup - or between all members

\footnotetext{
${ }^{56}$ The other four are Algeria, Egypt, Nigeria and South Africa.
} 
- of the regional grouping. (AFDB 2015) Specifically, Ethiopia's trade relations with countries of the region demonstrates low level of integration. Table 9 presents the total value of Ethiopia's external commerce (import and export) with IGAD members and their share of Ethiopia's total trade. It can be inferred form the table that none of the eight IGAD member countries are in the top ten sources of Ethiopia's imports in 2015 implying that Ethiopia is not significant destination to the goods and services of IGAD member states to use access to its domestic market as a leverage in bi- or multi-lateral relations. The Ethiopian market accounts for 0.88 percent of Kenya's export (2013) 0.01 percent of Sudan's export and 0.52 percent of Uganda's export (2012). The only outlier in this regard is Djibouti whose 35.4 percent of Djibouti's export in 2009 was to Ethiopia (World Bank 2015; see also Tekalign 2019:194-95).

Table 9. Ethiopia's Import and Export with Horn of African Countries (2015)

\begin{tabular}{|c|c|c|c|c|c|c|c|}
\hline \multirow[b]{2}{*}{$\begin{array}{l}\text { Partner } \\
\text { Name }\end{array}$} & \multicolumn{3}{|c|}{ Export } & \multirow[b]{2}{*}{$\begin{array}{l}\text { Partner } \\
\text { Name }\end{array}$} & \multicolumn{3}{|c|}{ Import } \\
\hline & $\begin{array}{l}\text { Export } \\
\text { (US\$ } \\
\text { millions } \\
\text { ) }\end{array}$ & Rank & $\begin{array}{c}\% \\
\text { Share } \\
\text { of total }\end{array}$ & & $\begin{array}{l}\text { Import } \\
\text { (US\$ } \\
\text { million } \\
\text { s) }\end{array}$ & Rank & $\begin{array}{c}\% \\
\text { Share } \\
\text { of total }\end{array}$ \\
\hline Somalia & 671.7 & 1 & 13.36 & Sudan & 82.1 & 31 & 0.32 \\
\hline Djibouti & 213.3 & 8 & 4.24 & Kenya & 43.6 & 37 & 0.17 \\
\hline Sudan & 110.1 & 11 & 2.19 & Somalia & 1.3 & 84 & 0.01 \\
\hline Kenya & 38.9 & 23 & 0.77 & Uganda & 0.409 & 97 & 0 \\
\hline Uganda & 11.5 & 38 & 0.23 & Djibouti & 0.353 & 100 & 0 \\
\hline South Sudan & 3.9 & $\overline{47}$ & 0.08 & South Sudan & 0.296 & $\overline{101}$ & 0 \\
\hline
\end{tabular}

Source: Michigan State University (2016)

Figures of Ethiopia's export paint a relatively different picture. In 2015 Somalia was the top destination of Ethiopia's exports; however, much of those exports are destined to the semi-independent Somaliland, rather than to Somalia proper. 
Djibouti and Sudan are also major destinations of Ethiopia's exports sitting at $8^{\text {th }}$ and $11^{\text {th }}$ place respectively. Both Ethiopia's export and import trade evinces a higher level of interdependence between Ethiopia and Djibouti highlighting the importance of Djibouti as Ethiopia's only viable outlet to the sea especially since the loss of Eritrea in 1991 and after the Ethiopian-Eritrean war ended the availability of Eritrea's ports for use by Ethiopia. Even in this case, however, it is a situation of mutual interdependence between Djibouti and Ethiopia, rather than a dominant-dependent relationship expected from the relations between a regional power and a small state. In contrast to Ethiopia's weak economic ties in the region, there are significant bilateral economic interconnections between other members. For instance, Uganda and Kenya are the principle destinations for each other's export (UNCTAD 2016).

\section{Military Capability}

States exist in an environment where internal and external threats to their security are both common and pervasive, and therefore the effectiveness of their coercive qualities is a fundamental yardstick of national power. Military capabilities allow countries to pursue their interests over and against the interests of other competing parties. At the same time, it enables them to defend themselves against both foreign and domestic adversaries (Tellis et al 2000). The value of military capability is accentuated in 'dangerous neighborhoods' such as the Horn of Africa that are linked to elevated security competition as a central element of interstate relations. 
A readiness to use military force to impose one's will is a central component of coercive power, and is closely associated to the realist tradition of international relations that analyzes the exercise of power primarily through a military dimension (Baldwin, 2016:129). Morgenthau's (1952) discussion of the elements of national power takes war-winning capability as the standard of judgement of national powers, which he regarded as military force conceived in the context of war winning ability. Waltz, for his part, argues that "the daily presence of force and recurrent reliance on it mark the affairs of nations... the possibility that force will be used by one or another of the parties looms always as a threat in the background. In politics force is said to the ultima ratio. In international politics force serves not only as the ultima ratio, but indeed is the first and constant one" (Waltz 1979:186 and 113).

Mearsheimer (2001) argues that a state's effective power in international politics is ultimately a function of its military forces and the balance of power is but tantamount to the balance of military might. "Great powers are determined on the basis of their relative military capability. To qualify as a great power, a state must have sufficient military assets to put up a serious fight in an all-out conventional war against the most powerful state in the world." (2001:5) Whereas a state can claim great-power status, it is unlikely to join the great-power club unless it meets the requirements of economic and military strength that grant admission to the club. (Bull 1977:201) Military force is also particularly attractive for its greater chance of fungibility - "the ease with which power resources useful in one issue can be used in other issue-areas" (Baldwin 2016:70). In short, militarily powerful 
states are more secure than militarily weak states; have greater clout in world and regional politics; are less subject to the influence of others; offer better protection to their allies; and can compel others to change their behavior (Art 1999:7). Regional powers are great-powers writ small, and the coercive qualities required to claim great power status is just as essential to regional powers.

Table 10. Military Expenditure Horn of Africa Countries (2011-2016)

\begin{tabular}{|l|r|r|r|r|r|r|r|r|r|r|}
\hline \multirow{2}{*}{ Country } & \multicolumn{2}{|c|}{2012} & \multicolumn{2}{|c|}{2013} & \multicolumn{2}{|c|}{2014} & \multicolumn{2}{|c|}{2015} & \multicolumn{2}{|c|}{2016} \\
\cline { 2 - 11 } & total & $\begin{array}{l}\% \text { of } \\
\text { GDP }\end{array}$ & total & $\begin{array}{r}\% \text { of } \\
\text { GDP }\end{array}$ & total & $\begin{array}{r}\% \text { of } \\
\text { GDP }\end{array}$ & total & $\begin{array}{r}\text { \% of } \\
\text { GDP }\end{array}$ & $\begin{array}{r}\text { to of } \\
\text { GDP }\end{array}$ \\
\hline Djibouti & $10^{*}$ & 0.7 & $11^{*}$ & 0.8 & n.k & n.k & n.k & n.k & n.k & n.k \\
\hline Eritrea & $78^{*}$ & 2.5 & $78^{*}$ & 2.3 & n.k & n.k & n.k & n.k & n.k & n.k \\
\hline Ethiopia & 254 & 0.6 & 351 & 0.8 & 375 & 0.8 & 399 & 0.6 & 448 & 0.7 \\
\hline Kenya & 930 & 2.2 & 975 & 2.1 & 1,042 & 1.7 & 942 & 1.5 & 908 & 1.4 \\
\hline $\begin{array}{l}\text { South } \\
\text { Sudan }\end{array}$ & 819 & 7.2 & 714 & 5.3 & 1044 & 7.3 & 1,346 & 10.5 & 525 & 3.7 \\
\hline Sudan & n.k & n.k & 1,892 & 2.8 & n.k & n.k & 2280 & 3.0 & 2465 & 3.1 \\
\hline Uganda & 374 & 1.8 & 342 & 1.6 & 405 & 1.6 & 362 & 1.5 & 398 & 1.9 \\
\hline $\begin{array}{l}\text { Region } \\
\text { Total }\end{array}$ & 2465 & -- & 4363 & -- & 2866 & -- & 3049 & -- & 4744 & n.k \\
\hline
\end{tabular}

Source: SIPRI (2017).

"Data obtained from IISS $(2014,2015,2016)$.

The balance of military power can be determined only by examining many variables, including the military expenditure of the region's countries and relative military balance using the size and quantity of a country's military force - the more traditional indicator for measuring national power. Table 10 records military capabilities as measured by the dollar amount of military expenditures. In 2013 the year data is available for all countries except Somalia- Sudan's military expenditure was the highest at eighteen percent of the regional total and twice the size of the next highest spender - Kenya. They are followed by the newest state of 
the world - South Sudan. The three countries combined accounted for eighty-two percent of the region's military expenditure in 2013. By 2016, Sudan's defense expenditure increased both in absolute terms and its share of the regional total rose to fifty-two percent ${ }^{57}$.

Table 11. The Military Balance - Horn of Africa 2016

\begin{tabular}{|c|c|c|c|c|c|c|c|}
\hline \multirow[t]{2}{*}{ Country } & \multicolumn{4}{|c|}{ Armed Forces } & \multirow[t]{2}{*}{ Other ${ }^{58}$} & \multirow[t]{2}{*}{ Reserve } & \multirow[t]{2}{*}{ Total } \\
\hline & Army & Navy & Airforce & Total & & & \\
\hline Djibouti & 8,000 & 200 & 250 & 8,450 & 4500 & & 12,950 \\
\hline Eritrea & 200,000 & 1,400 & 350 & 201,750 & - & 120,000 & 321,750 \\
\hline Ethiopia & 135,000 & & 3,000 & 138,000 & - & - & 138,000 \\
\hline Kenya & 20,000 & 1,600 & 2,500 & 23,100 & 5,000 & - & 29,100 \\
\hline Somalia & 11,000 & - & - & 19,800 & - & - & 11,000 \\
\hline South Sudan & 185,000 & - & - & 185,000 & - & - & 185,000 \\
\hline Sudan & 240,000 & 1,300 & 3,000 & 244,300 & 20,000 & 85,000 & 349,300 \\
\hline Uganda & 45,000 & - & - & 45,000 & 1,800 & - & 46,800 \\
\hline Region Total & & & & 865,400 & 35,300 & 205,000 & $1,105,000$ \\
\hline SSA Total & & & & $1,659,000$ & 250,000 & 213,000 & $2,122,000$ \\
\hline
\end{tabular}

Source: IISS (2017)

In addition to military expenditure, it is essential to know the size and quality of military manpower in order to assess national power as it relates to military capabilities. One must gather information about the total size of the force, the breakdown between those on active duty and those in reserve, as well as the distribution of personnel across the services. The above table substantiates the view that the Horn of Africa is one of the most militarized places in Africa where power politics is still relevant. In the most recent edition of its annual publication assessing the military balance of states, the International Institute of Strategic

\footnotetext{
57 The 2016 data excludes Eritrea and Djibouti for which data was not available.

58 Includes gendarmerie, paramilitary, and security forces.
} 
Studies (2017) demonstrates that the Horn of Africa - a region that comprises eight countries or about fifteen percent of the total SSA countries - accounts for roughly half of the total number of Sub Saharan Africa's armed forces.

In addition to having the highest military expenditure, Sudan has the largest army in the region. The primary focus of the Sudanese military, however, according to IISS, remains ongoing tensions with South Sudan and counterinsurgency in Darfur, with continued clashes with rebels in the south and the east of the country. Plus, "the Sudanese military has a limited regional power-projection capability although it contributed to the 2015 Saudi-led intervention in Yemen which is more symbolic" (IISS 2017:538). Kenya has a relatively small army but high military expenditure. Regardless, "Until 2011, the [Kenyan Defense Forces] KDF was effectively a peacetime army, exhibiting some of the issues that develop with many years of training but no operations on which to test capability" (IISS 2015:425). The lack of combat experience was exposed during Operation Linda Nchii - a military campaign into Somalia to dislodge al-Shabaab forces from the port city of Kismayoo in Southern Somalia. Kenya's armed forces invaded Somalia in October 2011, but the objective of capturing Kismayoo was accomplished only after more than a year of slow progress and sometimes hard fighting (Anderson and McKnight 2014).

Next to Sudan, Eritrea has the second largest army in the Horn of Africa. Eritrea's army exceeds 300,000 including its reserves. However, Eritrea's effectiveness is hampered by the constant state of mobilization with Ethiopia, sorry state of the nation's economy and low morale among the military. IISS states that 
"A steady trickle of Eritrean soldiers cross the border into Ethiopia, entering Eritrean refugee camps - at its peak, more than a battalion's worth of soldiers were arriving in Ethiopia every month. The preferential 'out of camp policy' for Eritrean refugees in Ethiopia, which allows refugees to continue schooling and, in some cases, to attend Ethiopian universities, is a positive incentive for desertion from the Eritrean armed forces. Morale amongst the majority, but by no means all, of the Eritrean conscripts is said to be very low (IISS 2017:492). Djibouti can afford only a small army and small expenditure as its security is guaranteed by the presence of its colonial patron France and more recently other foreign forces including the US, Japan, China, Spain, Germany and Saudi Arabia (ibid.:510).

The above data and analysis show that Ethiopia is far from being the most powerful state in the Horn of Africa in terms of military expenditure or the size of its army. The data suggests that Sudan should be the most powerful state in the region. It has the biggest army, and it spends the most by far compared to other countries in the region. Ethiopia has 135,000 active duty soldiers, only a bit more than one-third the size of Eritrea's and Sudanese armies. However, Ethiopia has one of the region's most effective armed forces, which have become battlehardened and experienced following a history of combat operations. (IISS 2017:512) Of the regional states, only Eritrea remains outside the circle of Ethiopian National Defense Forces (ENDF) engagement (IISS 2015:418) It is remarkable that Ethiopia, with all the military strategic pressures that emanate from its neighbors, has spent less in national defense both in absolute terms and as a portion of its GDP. In fact, the region's two most potent military powers - Ethiopia 
and Uganda - arguably the two countries with the strongest army with vast experiences of counter insurgency and active military involvement in neighboring countries, spent roughly equal amount of resources on their military - around eight percent of the total regional expenditure. Coupled with recent economic perfromance and increase in its GDP Ethiopia's low defense expenditure as a share of GDP implies opportunities to increase expenditure without necessarily overburdening other sectors of the eocnomy.

The core of the Ethiopian army comes from the EPRDF-led insurgency against the Derg. Since its transformation into the national army, the Ethiopian military has fought conventional wars against Eritrea (1998-2000) and in Somalia since 2006. Moreover, it has experiences in anti-insurgency in Somalia against alShabaab and low-key insurgency in the Ogaden region in Ethiopia. As of November 2015, Ethiopia was the largest troop contributor of all African countries to UN and AU peace- keeping missions. Therefore, it can be argued that Ethiopia's military has the experience and capacity to deploy in different combat situations. The only countries in the region with similar experience are Uganda and Eritrea, the core of which military originates from armed insurgencies and have taken part in both conventional and counter insurgency operations. However, Eritrea's primary focus is securing its border with Ethiopia. And whereas Uganda has the additional experience of peacekeeping (Somalia), its geopolitical attention is Central Africa than the Horn of Africa as a result of its location. 


\section{Chapter Conclusion: Ethiopia Punching Above Weight}

This chapter set off with the intention to test the hypothesis that a nation's regional leverage and clout is a function of its endowment in material capabilities. To that end, three variables - demography, economy, and military - have been discussed to investigate the possibility - or lack thereof - of concentration of power that emanates from control over resources. Even With all their imperfections, the above data shed light the distribution of material capailities in the Horn of Africa region. We can arrive at several conclusions from an analysis of the distribution of material capabilities.

First, whereas Ethiopia enjoys predominance in its demographic size, military and economic power is unevenly disributed among Horn of African countries so that no single center of power can be detected through pure reference to the figures. Although Ethiopia'could potentially become the largest economy in the region provided it sustains its recent remarkable economic growth, as the data in 2015 shows its economy measured by GDP is on par with Sudan and Kenya. Even in such a case, Ethiopia's preeminance will not be to the same extent as that of other well-defined regional powers in Africa such as Nigeria in West Africa and South Africa in Southern Africa.

Second, the absence of a regional power center in terms of material capabilities belies Ethiopia's prominent role and influence in the Horn of Africa that has been discussed in the chapters 2 and 3 . Ethiopia has emerged as the regional power center, while not yet enjoying clear superiority defined in terms of capabilities. Ethiopia does not meet the definition of a regional power as a state 
having a clear preponderance in terms of economic or military capacity and is willing to exercise that superiority. By the same token, some level of capability superiority is necessary for power projection. It is improbable that small-sized countreis like Djibouti or Eritrea would harbor the ambition of regional dominance. Therefore, objective material capabilities are necessary, but insufficient, conditions for emerging powers.

Third, given the relative weakness and instability of these states and the inconsistency of the balances of regional capabilities, there is not a clear enough concentration of power to classify any state as a regional power. Therefore, the measures examined above need to be contextualized for the Horn of Africa where state formation and consolidation are ongoing processes. This process of consolidating state capacity is one useful way to understand why regional states' ability to express power externally may be limited by domestic instability. In the next section of this dissertation, the historical-institutional evolution of the Ethiopian state will be examined based on the hypothesis that the domestic level could be a mediating variable when countries translate capabilities into power projection. The preliminary argument is that Ethiopia has largely punched above its weight meaning that it is able to influence more international actors, institutions, or regimes than would be expected based on its material capabilities. 


\section{A Historical Institutional Analysis of the Ethiopian State}

This chapter identifies and discusses critical junctures in Ethiopian political history with the view to identify major institutional changes to the state in Ethiopia that have conditioned its role in the Horn of Africa. The first two chapters of the dissertation laid the foundation for the subsequent components. The first chapter explored dyadic relations between Ethiopia and countries of the Horn of Africa to investigate Ethiopia's growing active influence in regional affairs. This was followed by the chapter 3 - an evaluation of Ethiopia's growing role using the three P's framework developed by Prys (2012) - perception of regional role, projection of interests and provision of public goods. This aptly demonstrated a recognition among the political leadership of Ethiopia's growing regional role; that Ethiopia has used its pole regional position to project its interests; and that Ethiopia has made tentative and incipient steps to be a provider of public goods in the region.

Chapter four turned attention to identify factors or sources of Ethiopia's rising regional influence. The first line of argument, often attributed to neorealist school of thought, contends that the preeminence of a state, at the regional or global levels, can be deduced from the distribution of resources or material capabilities. To that end military, demographic and economic figures among countries of the Horn of Africa indicate, at best, a multi-polar regional power structure and an even distribution of the different dimensions of power among the three major countries in the region - Ethiopia, Sudan and Kenya. Therefore, it is 
difficult to infer that Ethiopia's role is a result of its unmatched concentration of material capabilities in the region.

This chapter extends the explanatory factors to provide an alternative to a crude analysis of material capabilities. The theoretical backdrop to a focus on the evolution of domestic politics in Ethiopia is historical institutionalism. This line of analysis is predicated on the claim that domestic level institutional changes in the Ethiopian state can help explain the rise in Ethiopia's regional importance better than its predominance in material capabilities. To the extent that Ethiopia's relative material capabilities appear to be rising, this development must be the result of a more fundamental socio-political evolution. Rising relative capabilities are only an intervening variable. The deeper cause of Ethiopia's rising regional prominence are discussed in this chapter. Internal or domestic level account to Ethiopia's growing influence by using institutional analysis to analyze changes in the Ethiopian state to understand if or whether internal changes have contributed to Ethiopia's growing influence.

\section{Historical Institutionalism and the state}

A feature of historical institutionalism ${ }^{59}$ is its interest in examining unfolding historical processes and provide an analysis of internal politics embedded in

\footnotetext{
59 Although classical scholars have applied historical and institutionalist approach, historical institutionalism as distinct epistemological and methodological approach appeared in the 1970's. Much of the early works focused on comparative politics and have looked at institutions and events such as social revolutions (Skocpol 1978), state formation in Western Europe (Tilly 1975), states in economic development (Evans, Rueschemeyer, and Skocpol 1985), agricultural and industrial policies (Skocpol and Finegold 1990), social movements (Tilly 2004) and so on.
} 
history. The use of a historical institutionalist framework is analytically sound in the case of state transformation as "there is no way to create comprehensive, plausible, and verifiable explanations without taking history seriously into account" (Tilly 2006:421). An historical institutionalist approach stresses the role of critical junctures defined as "moments when substantial institutional change takes place thereby creating a 'branching point' from which historical development moves onto a new path" (Hall and Taylor 1996: 942; also see Mahoney 2000 and Pierson 2004). Historical events serve as foundational moments and changes during those times produce outcomes that have lasting effects that shape subsequent trajectories of political change. Linking past constraints created during critical junctures to future outcomes is achieved through a "process tracing" procedure that uses historical narrative to trace the interaction of actors and structure over time (George and McKeown 1985).

Once the relevance of an historical and institutional approach is established, the next step is to identify which institutions matter the most. For the purpose of this research, a macro level analysis of the Ethiopian state will be used. Emphasis on the state by the theories of international relations was popularized by the statecentric realist approach grounded on individual states as the primary and the most consequential actors in world politics. The central conceptual bases of neorealism are the closely intertwined differences between internal-hierarchical and externalanarchical orders. Decisions that have major external consequences such as wars and conflicts are ultimately decided by the state. The state has the ability of to 
make domestic or foreign policy and shape the domestic realm, free from domestic social-structural requirements or the interests of non-state actors (Hobson 2003:5).

Various scholars, however, have questioned the applicability to the interstate relations of Africa of state-centric methodologies that presuppose a centralized and functional political entity that has the monopoly of the use of force over a given territory and that can make laws and expect obedience from its subjects. Conventional international relations theories are inapplicable in Africa because few states in Africa meet such a definition. In what is referred to African exceptionalism, international relations in Africa differ from elsewhere because the central actor - the African state - fundamentally differs from elsewhere.

The first skepticism centers on the artificiality of African states and their boundaries which were imposed by colonial powers with little regard to history, ethnic homogeneity, and social interactions. Ottaway (1999:16) is typical in arguing that "African states attained independence through agreements with the former colonial powers, not through the emergence of strong leaders and governments that could establish effective control over territory and extract the resources necessary to sustain an independent state." The artificiality of the African states means that "weakened the capacity of most African states to govern effectively. The authoritarianism of many African governments, coupled with their incapacity to project power throughout their countries, has provided a fertile breeding ground for armed opposition movements."

A second line of argument underscores the implications of colonial intervention on the legitimacy of post-independence African states. For instance, 
it is argued that Africa has lagged behind other regions economically because it is disproportionately composed of illegitimate states that are historically incongruent with pre-colonial political institutions. Englebert (2002) contends that most African states lack legitimacy due to the colonial interruption of their pre-colonial political institutions. African states currently enjoying legitimacy often exist as reincarnations of legitimate pre-colonial political authorities. Due to their tenuous legitimacy, most African states at best qualify as "quasi states" that "cannot function as empirical states due to their lack of political and economic resources, their leaders face distinct pressures from within and without, such that the fundamental goal of leadership survival trumps all others" (Clapham 1996:266).

A third theme running through the literature on African exceptionalism is that international relations theory is challenged by the fact that, in Africa, official states are not the only important actors. Assis Malaquias writes, for example, that "in the African context, nations and armed nationalist movements are important units of analysis. By ignoring such important analytical units while concentrating mainly on the state, traditional international relations theory has not been able to explain, let alone predict, the behavior of African political actors on the world stage" (Malaquias 2001:12). The tendency to privilege official states may miss the real action in Africa. ${ }^{60}$ Timothy Shaw also argues that "studies of African international relations/foreign policies need to incorporate not only non-state actors but also new

\footnotetext{
${ }^{60}$ When describing Mobutu's Zaire, Dunn argues: "The state's control effectively ended a few hundred kilometers outside of Kinshasa, while the rest of the country operated through a web of complex power relations" (Dunn 2001: 52).
} 
security communities" (Shaw 2001: 218). For Clapham (1996), insurgent leaders in Africa often behave like state and their leaders as the head of states in their own right. Hence the study of African international relations should incorporate not only the study of the foreign relations of de jure leaders in and around the capital city, but also rebel groups engaged in their own interactions with the outside world.

Notwithstanding the strong argument for inclusion of non-state actors or qualifying the African state as quasi, I maintain that probing the state to explain Ethiopia's foreign relations under a succession of regimes is still sensible. First, the Ethiopian state has withstood colonial expansion and maintained its traditions and system. Using Engelhart's definition, Ethiopia can be considered a legitimate state since it has never been colonized and the precolonial state institutions have remained intact. Harbeson (1988:23) concurs: "Ethiopia's present international boundaries did not result from the actions of European powers but from persistent local territorial expansion within the northwestern highlands of the ancient Kingdom and, in the late twentieth century, to the areas now internationally recognized as included within the country." And despite structural similarities to several strong and centralized pre-colonial polities in Africa the Ethiopian state differs "by its greater organic linkage to society. In the rest of sub-Saharan Africa, state apparatuses were bequeathed by colonialism and thus lack indigenous roots" (Tareke 1991:26).

Second, the Ethiopian imperial state and its successors are perhaps the most powerful indigenous state structure in Africa. Clapham (1994:28) asserts that "Ethiopia is distinctive in modern Africa as the recognizable successor to an 
ancient indigenous African state, and the starting point for any analysis must, therefore be the historic Ethiopian state and the social basis on which it rested". Ethiopia maintained a tradition of statehood over many centuries that resurfaces even after long periods of eclipse. A tradition of statehood is evident from "the way in which highland Ethiopia has maintained, over many centuries, a level of continuous large-scale political organization found in few other parts of Sub Saharan Africa" (Clapham 1987:20).

Third, it is quite accurate that non-state actors play important roles in Ethiopia's foreign relations. For example, in his analysis of insurgencies in Africa, Clapham pointed out the EPLF and TPLF had considerable international networks and engaged in relations with donors and international NGOs to acquire food aid for the population under their control territory. However, the characterization of the state in Africa as having no or little control beyond several miles from the center or capital does not well describe the Ethiopian reality. Successive regimes have exercised control over the Ethiopian territory so much so that regime changes through revolution and insurgency have not diminished the authority of the state. ${ }^{61}$ There is a vital difference to the experience of the TPLF/EPRDF rebels upon seizing power in 1991 from the experiences of other African insurgencies throughout the horn who were seizing political power.

${ }^{61}$ Gebru Tareke (1991: 48 and 60) notes that it took three decades for Eritrean insurgents to liberate Eritrea, a country the size of Pennsylvania $(124,300 \mathrm{sq} . \mathrm{km})$ because the government they fought were too strong. 
The TPLF did not find themselves confronted by a tabula rasa of the kind that faced their contemporaries in the Somali territories and Eritrea. Instead, they inherited a state-a deeply problematic state to be sure, and one which would need to be reoriented away from the role it had played under the Derg, but a structured organization of government nonetheless. Civil servants stayed at their posts, and transferred their allegiance to the new regime, as indeed they had done when the imperial government collapsed in 1974. And this was not just the bureaucrats in Addis Ababa. In encompassed a hierarchy of rule that extended all the way down to the kebele, the peasants' associations and urban dwellers associations established during the [1974] revolution that remained in place as the basic unit of administration (Clapham 2017:66).

\section{The Ethiopian State in a Historical Context}

"There are few countries in Africa that are as enriched and burdened by the past as Ethiopia" (Tareke 1991: xii)

A study of Ethiopia's contemporary politics must, of necessity, have recourse to a Braudelian longue durée to uncover turning points in Ethiopia's political history. As a historical entity, Ethiopia is one of the oldest state formations still existing in the world. Its early history extends to the period before and during the state centered around the city of Axum starting from $4^{\text {th }}$ century B.C. However, for the purpose of this study, it is more appropriate to start in the middle $19^{\text {th }}$ century. The first rationale is that it was at this time that contemporary Ethiopia got its present-day demographic, geographic, and institutional shape. Starting from this period, the 
Ethiopian state apparatus slowly expanded both in space and depth to produce what is today identified as Ethiopian territory. By the end of the $19^{\text {th }}$ century, the Ethiopian polity assumed roughly the same population composition, and geographic shape and size that it currently has. Second, this was a period of increased interaction with the outside world, a process that started with contacts, with explorers and missionaries followed by diplomats and armies. It was the period of increased European interest and encroachment in Africa and Ethiopia that ended in the colonial scramble and the Battle of Adwa with Italy (1896), respectively.

After the beginning of the modern Ethiopian state, there have been several important breaking points in the evolution of the Ethiopian state. "Selecting benchmark dates as the beginning or endings of long and complex historical processes can be arbitrary, often faulty" (Tareke 1991:11). Nonetheless, much of the literature on contemporary Ethiopian history identify three turning periods starting from the mid-19th century: the formation of the state circa 1855-1896, the 1974 revolution that ended the Solomonic monarchy, and the fall of the nominally Marxist military regime in 1991. While the first one is the starting point of our historical context, it can plausibly be argued that the 1974 and 1991 are two critical junctures as they signified not only regime change but a fundamental restructuring of the state that had profound implication in the basic state structures, guiding mythologies, and ideologies and interactions with the outside world. The following part discusses the three periods giving a broad reconstruction of political development in Ethiopia. 


\section{Formation of the Modern Ethiopian State}

\section{Centralization}

The second half of the $19^{\text {th }}$ century is a critical watershed in the formation and evolution of the modern Ethiopian state. The period witnessed two distinguishable but interlinked processes: (a) the reconstruction and centralization of the state in the traditional Abyssinian core and associated modernization of state administration and apparatus and (b) the territorial expansion of the Kingdom to the south, southeast, and southwest, giving the polity more or less the geographical shape and areas of today (Bekele 2013; Tibebu 1995:49). The Ethiopian state prior to 1855 had been divided among different regional power centers with a titular Emperor or King at the center with no actual power - a period commonly known as Zemene Mesafint (The Era of the Princes). However, between 1855 and 1898, under the successive rule of three Emperors - Tewodros II (r. 1855-1868), Yohannes IV (r. 1872-1889), and Menelik II (r. 1889-1913) - the disparate Abyssinian kingdoms and principalities were unified into something approaching a single polity (Harbeson 1988:34).

The strong imperial rule reemerged with the coming to power of Emperor Tewodros in 1855 after nearly a century of disunity during the Zemene Mesafint. Tewodros started a gradual process to build a strong state-apparatus within the Christian highlands with the explicit goal of unifying the country under a single central government. He started concentrating power in his own hands at the expense of the regional centers of power by appointing his own vassals as regional

governors, securing the loyalty of provincial authorities to his imperial authority, 
creating a unified, national army, and limiting the influence of the Church. Although Tewodros did not succeed in many of these attempts, he did manage to rid the country of regional warlords so his successors could easily step into the state structure and ensure their dominance (Henze 2000:133-143).

This centralizing tendency continued under Yohannes IV and especially Menelik II. Menelik II continued the policies of his predecessors to centralize authority within the empire at the expense of the nobility. Menelik managed to develop internal communications links, instituted a modern administrative system, and installed the first cabinet. Local rulers were forbidden from having modern arms, taxation was further developed, and imperial courts were established all over the country. With these innovations Menelik's reign represented the triumph of the centralizing idea (Marcus, cited in Poulha 2004:174).

\section{Territorial Expansion}

A second major development in the second half of the $19^{\text {th }}$ century is territorial expansion that "turned the legendary Christian kingdom into a veritable empire." (Markakis 2011:3) It was the rulers of Shoa, the southernmost province of the Abyssinian center, who spearheaded the adventure to incorporate nearby territories. After he became Emperor in 1888, Menilik expanded and completed a process of territorial expansion that had been underway when he was still King of Shoa (Markakis 2011:90; Tibebu 1995:31).

The expansion had dialectically connected but contradictory implications on the process of nation and state-building. On the one hand, it dramatically increased the power of the state. (Bekele 2015) Through the distribution of land, the state 
augmented its material capacity and was able to co-opt a large following. The area of Arsi which was conquered in 1886 became a dependable source of agricultural wealth and revenue (Henze 2000: 152). Harar (conquered in 1887) was an important trading city and "a major transit route to trade in south Ethiopia, the main of which was trade in slaves...which was highly profitable...Shoan conquest in the south brought peace and greatly increased production of traditional products such as coffee, civet, ivory, honey, ostrich feathers, furs and hides" (ibid.: 153; Marcus 2002: 81; Markakis 2011: 93-94). Gambella in the West, rich in trade in slaves and ivory and potential for coffee and rubber, became an important entrepot for Ethiopia's foreign trade (Markakis 2011: 105).

In general, Marcus (2002: 96 ) notes that by the turn of the $20^{\text {th }}$ century, conditions in Ethiopia were "generally satisfactory...the Emperor had just conquered prosperous Walamo and taken rich booty...the regional granaries were brimming...there were no annoying dissidents." Clapham (2019:35) concurs that the northern Abyssinain core was subject to progressive ecological degradation and was barely capable of sustaining its own population... producing very little that could generate income from the global economy". The Ethiopian state made up for this shortcoming by "conquering vast areas of territory, especially to the south and west of the highland zone, which helped to provide it with a much more resilient economic base, including export crops of which the most important was coffee".

During the battle of Adwa (in 1896), the Imperial state managed to mobilize an army of roughly 100,000 soldiers recruited from the newly conquered lands and under the feudal vassals. Ethiopia was in a much stronger position to face 
European encroachment under a strong state which natural and human resources had grown. In fact, one motive for the conquests was said to have been the survival of the Abyssinian state itself during the scramble for Africa. Given its limited human and material resources, Ethiopia could not withstand the European threat on its own. Thus, Menelik decided to subjugate the southern and southwestern territories, and revive his kingdom's fragile economy, and eventually to turn attention to the defense of his empire against European encroachment. In addition to resources, through the incorporated regions Ethiopia acquired a broad territorial buffer zone to protect the nation politically and economically from European encroachment (Gnamo 2013:1154-15).

On the other hand, the conquests created new, fundamental, and still unresolved questions concerning the foundations of state formation and underlying Ethiopian political identity. The nation-building process in the aftermath of territorial expansion and conquest, an unfinished project of nation building, has been challenging. The expansion transformed a relatively homogenous Abyssinian polity into a modern Empire with an amalgam of heterogeneous groups. Moreover, the process of unification and expansion was achieved often through blood and iron, "a process involving conquest, land alienation and a great deal of exploitation" (Clapham 1994:29). New land tenure systems were imposed for the purpose of consolidating and maintaining the regime's political and military control. The conquered lands were divided among collaborating local elites, royal kinsmen and elites of the northern dominion, soldiers, the church, and imperial subjects 
migrating south from overpopulated areas of the north. Thus, the people in the conquered lands

became the tenants and tributaries of the conquerors and their agents...giving up anywhere between 50 percent to as high as 75 percent of their produce over and above taxes to local and national authorities [In so doing] Menilik sic? opened up new and serious questions about [the] existence, nature and validity of the Ethiopian polity that his predecessors had devoted their reigns to resurrecting (Harbeson 1988: 35 and 73-74; see also Markakis 2011:97 and Henze 2000: 152).

The expansion had economic and social-cultural implications. Economically, the alienation of land in the grain growing areas often by, but not limited to, settlers from the north reduced indigenous population to the level of serfs. The predominantly Amhara minority extracted a particularly high proportion of the agricultural surplus and appropriated for itself the larger share of it.

...the country's most valuable resources, especially fertile land, were found in the territories incorporated by the expansion. The exploitation of these resources was based on a system of accumulation that depended on coercion...this archaic mode of exploitation was labor intensive and required the involvement of a very large number of beneficiaries in the process. Accordingly, a commensurate number of people moved from the Abyssinian homeland in the northern plateau to the conquered territories in the south to control and administer them. Many more followed to take advantage of fertile land offered by the imperial state practically for free in order to expand its tax base and to exploit native labour in conditions of quasi-serfdom. Appropriately known as neftegna (gunmen), the northerners comprised a ruling class that was essential to the maintenance of the imperial state and its economy. It was large, armed and a pillar of the imperial state (Markakis 2011: $6)$.

Socio-culturally, nation-building meant the imposition of the northern way of life over the conquered, mainly southern, population. Integration of the conquered population in effect entailed highland Abyssinia writ large. Amharic was the 
Empire's sole official language ${ }^{62}$ and the Coptic religion was a state religion (Lefort 1983:34) The subjugation of the south "created a subject population who could be much more readily exploited for the market than the Amhara and Tigrean of the northern plateau, who retained traditional social hierarchies..." (Clapham 1994: 32). The language, religion, and culture of the conquered peoples were relegated to secondary status, which induced resistance. The Amhara-dominated imperial ruling class, exercised a near monopoly of economic and social status and the imperial state was founded on what has been called an Amharaization.

Amharigna was named the official language of the state in the 1955 constitution but, long before that, no vernacular was allowed to be printed, broadcast, taught, or spoken on public occasions. Private schools were permitted to use foreign languages as long as they taught Amharigna as a subject, but no school could use an indigenous language, or teach it as a subject. Proficiency in the official language was required for entry to the University, although its language of instruction was English (Markakis 2011: 126).

Although class divisions and polarization had existed in the northern Abyssinian polity as well, they had been tempered by two factors (Tadesse 1993:22-23). First, the prevalent land tenure system in the north, called the rist, ensured access to land to anyone who could trace their lineage to a given locality and, hence, rendered alienation of land difficult. Second, cultural affinity between lord and serf diluted class contradiction. In the north, both originated from the same ethnic group

\footnotetext{
62 "Language, the emblem of culture," opines Markakis, "is the cutting edge in the process of homogenization." (2011: 1250) With reference to education, Moderchai (1970: 57) also argues that "[M]odern education in its present state in fore, rather contributes to than dispels the grievances elements among the population. Instead of doing away between the traditional ruling peoples and the ruled, it sharpens instead of moulding the nation into a more homogeneous.
} 
(Amhara/Tigre), spoke the same language (Amharic/Tigrigna), followed the same religion (Orthodox Christianity), attended the same congregation and worshipped the same God. In the south the majority of the landed classes came from the north with a different ethnic background, different culture and language, and mostly different religion.

In the Abyssinian homeland, the term gabbar referred to the tributary status of the free peasant who had secure (rist) rights over his land. The peasant in the periphery who found himself on land expropriated by the state and allocated to others, lost whatever rights he had over such land and was reduced to the status of a tenant...the burden imposed on the cultivator in the periphery was much heavier than borne by the Abyssinian peasant, whose rights and obligations were prescribed and protected by traditional law and custom shared with his governor. The gabbar in the periphery had no recourse against an alien landholding class. And could not refuse a landlord demand (Markakis 2011:100; italics added).

Thus, the pattern of state formation and patterns of social and economic change produced explosive confluence of ethnic, cultural and class cleavages that threatened the very process of nation-building and opened up a way for external forces to intervene.

Founding the imperial edifice on a system of land tenure imposed and maintained by force proved to be a structural flaw, that is, the fateful conjunction of ethnic and class divisions in the unique neftegna ${ }^{63}$-gabbar coupling. The great majority of the neftegna were Christian, Amharigna and Tigrigna-speaking Abyssinians, a distinct nation in a region inhabited by many other groups, speaking various languages and adhering to Islam and traditional faiths. The distinctiveness of the Abyssinian identity was accentuated by a monopoly of political power, economic privilege and superior social status. All Abyssinians who settled in the highland periphery become landlords on expropriated land and exploited labour of the indigenous peasantry. The relationship between them was that of

\footnotetext{
${ }^{63}$ Literally meaning gun owners, the term neftegna derives from neft (meaning gun in Amharic) is a general term referring to those who moved from the north and settled in the south.
} 
master and servant, landlord and tenant, tax-collector and tax-payer. This conjunction [of class and ethnic identity] made for a potentially explosive outcome that took only decades to mature (Markakis 2011:107; see also Markakis 1974: 286-87; Tadesse 1993:22).

One of the eventual results of the combined process of state and class formation was an escalation in ethnic and regional conflicts. The imperial state faced challenges arising from the demands of various national groups as regionalism, as a manifestation of particularistic sentiments anchored in special relations, became a major basis of conflict. The politicization of ethnicity in the $20^{\text {th }}$ century especially in the period following the end of Italian occupation in 1941 became more evident (Tareke 1991:29).

\section{Growing ethno-regional dissatisfaction}

The politicization of ethnicity and emerging ethnic consciousness in the 1960's affected the state in several ways. First, it challenged the notion of Ethiopia as a unified and peaceful/stable polity in the region. Hailesellasie's regime had painted an image of Ethiopian as an ancient state that is peaceful and is an island of stability in a sea of turbulence. The imperial project "sought to unify the ramshackle empire within one national identity by restricting the expression of ethnic and cultural differences. It stressed the idea of Ethiopia as an integral whole with uninterrupted historical continuity from Axumite period in the first millennium to modern time" (Tareke 1991:31). The radicalized students Leading the students' movement rejected the notion of Ethiopia as a museum of nationalities (museo di popoli - a phrase coined by an Italian scholar Conti Rossi) and called Ethiopia a prison house of nationalities. 
Second, it fed into the growing civilian and student opposition to the regime, thereby weakening the regime. The Ethiopian Students' Movement (ESM) was the most consistent opposition the Imperial regime faced. It started during the 1960 attempted coup by the Imperial Bodyguards and continued unabated until the 1974 revolution. In 1969, during the height of peasant rebellions in the provinces of Bale (Southern Ethiopia) and Gojjam, and ongoing insurgency in Eritrea, the ESM adopted a radical line on what it labeled the question of nationalities supporting self-determination up to and including secession. Next to land to the tiller, selfdetermination became a major rallying slogan of the ESM and the revolution (Tadesse 1993; Balsvik 1985).

Third, popular revolts increasingly tested the authority of the state in Eritrea (1960-1974), Tigray (1942-44), Gojjam (1963), Bale (1963-70), Ogaden (1963), and Gedeo (1941). The 1974 revolution that brought the monarchy down was largely an urban affair, but the rural revolts contributed indirectly by overstretching the resources of the imperial army, sapping the financial and political capital of the regime. The Imperial army, the largest at the time in Sub-Saharan Africa whose training and weaponry were provided by the USA, was kept busy suppressing rebellions that flared up in various parts of the country (Markakis 1989:119-120). By the beginning of the 1970's, the bulk of the army was "pinned down by the rebels in the peripheries and, hence, forced to live in the arid and semi-arid regions of the lowlands often exposed to thirst, hunger and squalid conditions of life as well as to eminent danger of death in a war the end of which it could not see". (Tiruneh 1993:48) Halliday and Molyneux argue that although provincial revolts had not 
played a direct role in the overthrow of the imperial regime, they "helped to weaken the imperial state and to divide its personnel into rival factions" (1981:156). These disparate revolts failed to cohere [and] could not survive the state's repressive machinery (except in Eritrea), but imposed considerable strain on the state's financial and military resources (Tareke 1991:31; Henze 2000: 263).

Fourth, the ethnicization of the polity opened the door for external powers with aspirations to challenge Ethiopia's sovereignty and influence in the region. The multiethnic character of the Ethiopian society and the challenges of nationbuilding paved the way for external powers to intervene. In the first half of the $20^{\text {th }}$ century, while the rest of Africa was still under the yoke of colonial rule, the major challenge came from the proximate colonial powers, especially Italy, which has been looking for an opportunity to avenge the defeat at Adwa and retained a colonial ambition over Ethiopia. The Italian invasion and occupation (1936 - 1941) exposed ethnic fault lines in Ethiopia. At that time, Ethiopia was, by European standards, a fragile empire rather than a cohesive state, and its fragility was exploited by the Italian conquerors (Spears 2013:41). A distinctive feature of the Italian administrative and political configuration was adherence to the principle of ethnic identity "evoked less out of concern for self-determination than in line with the old adage divide et impera ('divide and rule')" (Zewde 2014:191).

The collapse of Ethiopian army and advent of Italian rule unsurprisingly "gave vent to acts of revenge and hopes of emancipation among the subject peoples" (Markakis 2011:113). In some instances, the Italians "had been welcomed as liberators by some of the [local] Kingdoms annexed to the empire 
half a century earlier because they brought with them the hope that they would return them their right to wealth" (Lefort 1983:33) In the northwest Ethiopia, Oromo chiefs in Wallega, Jimma and Illubabor created what came to be known as the Western Oromo Confederacy and petitioned Britain to be ruled under a British mandate from League of Nations (Markakis 2011; Keller 1998; Gebissa 2002).

The exploitative peasant labour corvee (gabbar) system which still existed in many areas was ended by the Italians, and this was seen as a liberation by many of the rural underclass. The Italians systematically favoured the Muslims in Ethiopia at the expense of the Christians. They provided full freedom of religion for Muslims, stimulated Islamic education and the introduction of Arabic in schools, built fifty new mosques, and supported Muslim leaders financially (Hussein 1994: 776). The Muslims thus largely welcomed Italian policy, and this did not endear them to the Ethiopians fighting for national liberation (Abbink 1998:117).

After Italy was defeated with the support of British forces and the threat of colonialism abated, resistance to centralization and class and national oppression mushroomed in the second half of the $20^{\text {th }}$ century with the encouragement or support of Ethiopia's regional foes. According to Lefort (1983:111), revolts in various part of the country became large scale where, inter alia, they had support beyond the frontier. Somalia's independence and unification in 1960 encouraged the outbreak of a rebellion in Ogaden among ethnic Somalis and in Bale by eastern Oromo Muslims. The new Somalia state helped incite the revolt, and it armed, trained and financed the rebels to achieve its expansionist goals (Tareke 2011:138; Marcus 2002:178). The Bale rebels received material support from Somalia which capitalized strongly on Oromo nationalism. The revolt "was able to sustain itself longer than the others in part because ethnic particularity conjoined 
with geographic marginality and logistical support it received from the state of Somalia, which was in the midst of territorial disputes with [Ethiopia]...was unmatched anywhere but Eritrea" (Tareke 1991:14). In addition to ethnicity, Mogadishu encouraged the insurgents to emphasize Islam as a common denominator to reduce the potential for difference between Somalis and Oromos and depicted their struggle as a jihad against Christian Amhara domination (Henze 2000:263).

During the same period, Muslim landowners protested Ethiopia's annexation of Eritrea in 1962 (Prunier 2013). In Eritrea, external support was readily provided by Egypt, Syria, Somalia, Iraq, Yemen, the PLO, and Sudan. In July 1960, a group of mostly Muslim exiles living in Cairo announced the establishment of the Eritrean Liberation Front (ELF). Middle Eastern Arab governments were attracted to the idea of supporting a largely Muslim rebellion in a country tied to the United States and Israel64 (Marcus 2002:175; Henze 2000:275). The Eritrean nationalist movement and the Bale revolts turned out to be the catalysts of the 1974 revolutions (Tareke 2011:53). They laid bare the Ethiopian government's failure to undertake political, social and economic programs sufficient to win the allegiance of the people. They challenged the ideological and material basis of the Imperial state and, ultimately, contributed to the collapse of the monarchy.

\footnotetext{
${ }^{64}$ During the $10^{\text {th }}$ anniversary of the formation of the OAU in 1973, President Boumeidian of Algeria promised to use his influences to discourage Arab support for the ELF if Ethiopian authorities that if Ethiopia severed diplomatic ties with Israel. (Andrgachew TIruneh ) The Emperor declined the offer, but was obliged to break diplomatic ties with Israel in tandem with other African governments in the wake of the October 1973 Yom Kippur War of October 1973.
} 


\section{The Aftermath of the 1974 Revolution}

In December 1974, soldiers in a remote outpost of southern Ethiopia mutinied over living conditions and unending wars in Ogaden and Eritrea. What started as a small-scale, isolated incident instigated a popular movement that, within six months, removed HaileSelassie from power and consigned the monarchy to the annals of history. The 1974 revolution was arguably the most momentous event in contemporary Ethiopian history as it shook the country like no other event since the formation of the state. The rupture the revolution caused marks an important turning point in the nation building project and the opening of a phase under a new political order. (Markakis 2011) According to Leenco Lata (1999:190), a veteran leader of the OLF, the Derg undertook three prominent reforms that were welcomed by the Ethiopian population: (a) ending the antiquated land tenure system (b) scrapping the theocratic nature of the Ethiopian state, and (c) officially recognizing the national (ethnic) diversity of Ethiopia.

The 1975 "Land to the Tiller" Proclamation

The Derg's nationalization of rural land transformed an urban-centered movement into a radical social revolution. A commentary on the socio-economic causes and implications of the reform is beyond the purview of this thesis. However, it is central to the institutional evolution of the Ethiopian state as it relates to nation/state building. The previous section of this chapter stipulated that the question of land in Ethiopia had implications that extend beyond mere socio-economy to national security and survival of the country. In the southern parts of the country in particular, issues of land and nationalities converged to reveal social cleavages 
along ethnic lines. Land, being the highest value for all segments of society in agrarian Ethiopia, had emerged as a source of continuous controversy and a major hurdle in the quest of nation-state building (Markakis 2011:10). Therefore, the means with which the revolutionary government grappled with the land question would directly impact the issue of nationalities and inter alia that of nation-state building.

Radical elements within the students' movement had recognized the explosive confluence of national and class divisions in the periphery posed a serious threat to the security of the Ethiopian state and were eager to defuse it (Markakis 2011:170). After a series of tentative steps that gradually aligned it to the left of the political spectrum, the military regime in March 1975 took the most radical and sweeping measure of the revolution when it nationalized all rural land. The land reform "limited holdings to a maximum of ten hectares, forbade the selling and renting of land and the use of hired labor, and redistributed land equally among those who tilled it. Landlordship and tenancy were eliminated overnight, and the possibility of land accumulation in the future was precluded" (Markakis 1989:122).

The Land to the Tiller proclamation as it came to be known was a landmark in Ethiopia's history. It symbolized a clear break with the past and in one stroke eliminated the economic foundations of the ancien régime. It encapsulated many years of efforts to address the most visible failings of the old order and signified a commitment to ending rural socioeconomic inequality and exploitation that were the features of the feudal system (Harbeson 1987:132-134). 
It also had a significant political significance for the process of state and nation building as it eliminated the structural foundations of national oppression and dissolved the ethnic and class conjunction in the south that many believed imperiled the survival of the country. In the immediate period, the land reform nullified the economic dimension of the nationalities question and diffused ethnic polarization in the peripheral areas. Pausewang opines that, without reform, "...Ethiopia might today face an Oromo resistance movement compared to which the Eritrean and Tigrean fronts would look like Sunday schools. Indeed, Oromo peasants were the prime beneficiaries of the land reform" (1990: 46). In the words of Markakis, the reform "severed the link that had joined class and national divisions in a politically explosive blend [and thus] had a greater impact on the center/periphery relationship than any other event thereafter" (Markakis 2011:170, emphasis added).

Due to different land tenure systems, the reform was more popular in the newly conquered regions of southern Ethiopia than the historic provinces of the north. Its impact was felt mainly in the incorporated periphery where it created enthusiasm for the revolution among the southern peasantry who, unlike their northern counterparts, had lacked the security provided by traditional systems of land tenure. Following the proclamation, southern peasants, Oromo peasants in particular, defended and consolidated the revolutionary gains (Tareke 1991: 145). With this newfound popularity, the regime was able to defeat its internal and external challengers. Although land reform failed to achieve long term economic transformation, 
it was outstandingly successful in removing the major form of social and economic oppression in southern Ethiopia, and goes a long way to explain why most of this area remained politically quiescent for the subsequent 15 years...Apart from the Somali war of 1977-78, southern Ethiopia provided little effective overt opposition to the regime until late in the 1980's, when organized opposition from the OLF started to emerge (Clapham 1994:35 and 37).

The popularity of the regime and its land proclamation accounted for the inability of dissident groups to inspire the peasants. The intellectuals in the cities failed because the land question, the basis of national oppression, had been partly resolved, diluting one of the major demands and mobilizing weapons of the 1960's. ${ }^{65}$ ( Tareke 1991:145).

Although the recently conquered regions of the south and west have been culturally far less closely attuned to the dominant group, have been subject to a vastly greater level of economic exploitation, and have been virtually excluded from central government office, attempts by Oromo and other opposition movements to mobilise ethnic identities against the central government have achieved nothing remotely approaching the success of the opposition movements in the north.

Popular enthusiasm towards the revolution mainly from the southern peasantry was reflected during the Ogaden war of 1977-78. Peasants of the southern regions, in particular, became strong allies of the revolutionary government and played a decisive role in the defeat of Somali aggression. Siad Barre's regime in

\footnotetext{
65 In his account of the EPRP, the main civilian opposition to the Derg, Kiflu Taddesse (1993:209) writes that the land proclamation measures "outstripped the radical agenda and outdated the economic content of the EPRP program." the radical land reform also improved the Derg's standing with socialist governments. With regards to international connection, Kiflu (1993: 232-33) states that the government of North Yemen, which maintained close contact with the EPLO (EPRP's predecessor) started to put pressure for reconciliation with the military regime after the enactment of land reform. The Yemeni rejected the question of armed struggle [by EPRP against the Derg] altogether and found it difficult to understand how the organization could wage an armed struggle against a government that had proclaimed a radical land reform".
} 
Somalia sensed an opportunity as the new regime in Addis was absorbed in the struggle on multiple fronts against remnants of the feudal regime, clandestine organizations of the civilian left and ethno-national rebels in Ogaden, Eritrea, and Tigray. It started by providing training and equipment to WSLF insurgents in the restive Ogaden region and used SALF to penetrate into areas inhabited by ethnic Oromos. Ultimately Somali regular troops crossed into Ethiopian territory in June/July 1977. Within days, the SNA penetrated deep into Ethiopian territory, seized $350,000 \mathrm{~km}^{2}$ territory (about 90 percent of Ogaden) and captured major cities including Jijiga and Dire Dawa. The Derg declared a nationwide military campaign to save the motherland which included the mobilization of reportedly 300,000 strong peasant militia army for the war. The militiamen,

though unskilled and inexperienced, turned out to be remarkably tenacious, the resolve and bravery with which they fought must have established not only the Somalis but also their own leaders. The militiamen were inspired by dream or hopes of social justice and a transformed world. Many of them were from the southern regions, primary beneficiaries of the land reform legislated in early 1975. There was much at stake for them to defy the gains of the revolution as well as the territorial integrity of the country. With their patriotic and revolutionary enthusiasm, they helped halt the enemy from undermining both (Tareke 1991:213).

Whereas the WSLF was welcomed by the Ogadenees and the Hawiya of Bale, the SALF's appeal to ethnic and religious sentiments of Oromos fell mostly on deaf ears. Oromo peasants evinced little enthusiasm to take up arms against a government that had just abolished tenancy that had oppressed them for nearly a century (ibid.:189) Thus the revolutionary army that defeated the Somali army and pinned back the Eritrean rebels was to a very large extent composed of Oromo 
and other southern peasants, who strongly identified with the revolutionary state and saw themselves as defending their revolution against domestic and external foes (Markakis 1988:24; Clapham 2004).

An equally important facet of the land reform legislation was its drive to organize farmers into associations. At the general level, the revolution ushered in a fundamental institutional transformation by abolishing the monarchy and creating a republic. At the local level, the land proclamation established Peasant Associations (PA) to ostensibly provide extensive grass roots self-administration. The main function of the PAs at the initial stage of their existence was to administer land redistribution with the support of students who had been sent to the countryside under the rural development campaign. In addition, PAs were responsible for setting up marketing and credit cooperatives, establishing schools and clinics, undertaking villagization projects, and caring for the helpless among the young and the old. Subsequent proclamations added security responsibilities such as raising militias for local defense to supplementing the ranks of the national army (Tadesse 1993:206; Harbeson 1988:132-134; Bekele 1982).

The PAs, together with the Urban Dwellers Associations (UDAs) ${ }^{66}$ in the cities, facilitated government penetration and control at local levels. In the pre-

\footnotetext{
66 The urban land reform, proclaimed in July 1975, nationalized privately rented (extra) housing. The UDAs, the organization vested with the responsibility to implement the reform, were given a wide range of administrative functions. The kebele, the lowest level of urban governance, provided the ration cards which families in major towns needed to procure their allocation of subsidized goods including food. It had its own administrative headquarters, its judicial tribunal, its shop, and its women's and youth organizations. It provided the structure through which to run literacy campaigns, to get out the crowd for obligatory demonstrations, and to enforce the military conscription. Its armed guards policed the streets at night enforced curfews. (Clapham 1989)
} 
revolution period, the state apparatus was too superficial to penetrate the basic peasant community. It did have a presence in the awraja (county) but the administration was no more than skeletal in each woreda (district). One administrator and a few government agents were in charge of an average population of 5000 inhabitants and their administrative role was confined to maintaining law and order and collecting taxes (Lefort 1983:91). Initially autonomous, PAs were promptly brought under the control of a hierarchy imposed from the center and capturing peasants through them thus became critical to locallevel administration. For the first time the Ethiopian government instituted a mechanism through which power-hitherto dispersed between a myriad of local actors_could be concentrated in state hands (Clapham 2019:38).

The question of nationalities: ethnic and religious diversity of Ethiopia

The military regime dealt directly with the question of nationalities in addition to reforming land tenure to address its redistributive aspects. To begin with, the revolution sought to put all the nationalities of Ethiopia on an equal footing by recognizing the existence of the question and the centrality of ethnic identity for many Ethiopians, a policy strongly resisted by the imperial regime. Important and genuinely radical steps were taken to equalize ethnic communities from the rehabilitation of a number of languages to the official recognition of Islam. Muslim holidays were officially recognized for the first time (Smith:73 and 75; Lefort 1983). Advised by a faction of the radical intelligentsia, the government made some formal concessions to demands for regional autonomy in the National Democratic Revolution (NDR) Program issued in 1976. 
The right to self-determination of all nationalities will be recognized and fully respected. No nationality will dominate another one since the history, culture, language and religion of each nationality will have equal recognition in accordance with the spirit of socialism. The unity of Ethiopia's nationalities will be based on their common struggle against feudalism, imperialism, bureaucratic capitalism and all reactionary forces. This united struggle is based on the desire to construct a new life and a new society based on equality, brotherhood and mutual respect. Nationalities on border areas and those scattered over various regions have been subjected to special subjugation for a long time. Special attention will be made to raise the political, economic and cultural life of these nationalities. All necessary steps to equalize these nationalities with the other nationalities of Ethiopia will be undertaken. Given Ethiopia's existing situation, the problems of nationalities can only be resolved if each nationality is accorded full right to self-government. This means that each nationality will have regional autonomy to decide on matters concerning its internal affairs. Within its environs, it has the right to determine the contents of its political, economic and social life, use its own language and elect its own leaders and administrators to head its internal organs. This right of self- government of nationalities will be implemented in accordance with all democratic procedures and principles. (cited in Clapham, 1988:199)

Further attempts directed at the issue of nationalities were taken in the cultural realm as the regime endorsed cultural pluralism and actively promoted the cultural emancipation of ethnic groups. The ban on printing and broadcasting in languages other than Amharic and English was lifted, and Radio Ethiopia began broadcasting in other Ethiopian languages. The Oromo newspaper Barissa was officially promoted. And national literacy campaigns were conducted in fifteen 'nationality languages' (Vaughan year: 287).

In addition, and in a clear departure from its predecessor, the military government issued a nationalities policy and established an Institute for the Study of Ethiopian Nationalities. The Institute was founded in 1983 for the purpose of 
studying the ethnic composition of the country, in preparation for a constitutional design embodying regional self-government. The Institute meticulously demarcated and created a set of thirty regions which corresponded as accurately as possible to the mosaic of Ethiopian nationalities to counterweight the demands of the various separatist movements, a political sensitivity the regime has rarely shown. The 1987 Constitution also granted regional autonomy to the troubled regions of Eritrea, Tigray, Afar, Dire Dawa and Ogaden (Keller 1998).

Clapham opines that " $[\mathrm{H}] \mathrm{ad}$ the structure been introduced much earlier in the revolution, and at a time when there was general acquiescence with the basic goals of the regime, there would have been at least a chance that it might have provided an acceptable balance between the demands of national unity and the recognition of regional diversity" (Clapham 1989). The new administrative structure, however, failed to end the spreading civil war mainly for two reasons. First, by the time the Constitution was enacted in 1988, the civil war had already spread, and the military suffered a series of decisive defeats in Eritrea and Tigray. Second, many doubted the regime's commitment to devolve actual power to the local levels. In fact, the move was perceived as a means to weaken the rebel movements. The Afar (Assab) autonomous region for instance was created by taking territory from Eritrea and Tigray.

\section{Enduring challenges}

Notwithstanding its progressive policies towards ethnic identities, the nationalities question turned out to be the Achilles heel of the military regime. Its policies on the expressions of ethnic identities mismatched its obsession with absolute control, 
and reluctance to share power with opposition groups or confer a degree of autonomy to the local levels. As a result of its suppression of any form of dissent, and the neutralization of the civilian left during the Red Terror early during the revolution, radical intellectuals turned to ethnic and regional mobilization as the most effective routine for waging political struggle. According to Hiwet,

a lasting solution to the nationalities question would have a profound impact on the degree of democratisation of state and society in republican Ethiopia. This intractable problem, unlike others, cannot be militarily decreed. It demands more than the formal recognition of the fraternity and equality of nationalities and token concessions on languages. It must be structurally inscribed in a democratic state system. This, by definition, negates the very essence [of the Derg] (Hiwet 1984).

Moreover, ethnic autonomy proved incompatible with two of the revolution's driving forces - radical Marxism as the regime's stated ideology and Ethiopian nationalism as a commitment to the nation-state project (Markakis 2011:161). Owing to its universalist ideology and penchant for centralization, the Derg's socialism was even less suitable to accommodate decentralization and regional autonomy than Haile Selassie's regime. Marxist ideology treats ethnic divisions as subordinate to class contradictions, whose resolution would lead to the eventual solution of other layers of contradictions. Hence the Derg felt that resolving the material basis of national domination through land redistribution would eventually liberate the country from inequality along ethnic lines. Once oppression and inequality were done away with, and the injustices of the old 'feudal' system were rectified, notably with regard to the land question, then the basic underlying causes of Ethiopia's 
internal divisions would no longer exist, and all Ethiopians could join together as members of a single equal and united nation (Clapham 2004).

Granted, land distribution neutralized in the near term the centrifugal tendencies represented by the demand of constituent ethnic groups for their right to self-determination. As a result, the regime gained broad popular support especially in the rural areas of southern Ethiopia. However, despite its short-term success in removing the major form of social and economic oppression in southern Ethiopia, the reform failed to inspire long term economic transformation. Furthermore, the government subsequently initiated ill-advised and unpopular agricultural policies ${ }^{67}$ that undermined its support among the peasantry. The burden of financing the interminable wars fell on the back of small-scale peasant agriculture, and

the state's consuming goal of winning the civil wars at all cost increased the premium of the rural economy. Economic and social matters were subordinated to the overriding needs and demands of the state and its military. To get what it wanted, the state resorted to extensive coercive methods. The party and affiliated civic associations - peasant, women, youth - were used to mobilize and control rural producers for surplus extraction, capital accumulation, war making. The peasant associations, which were vital democratic components of the revolution, were converted into bureaucratic tools of subordination, control and exploitation. The state levied taxes and demanded contributions, the associations collected dues and helped organize the militias, while state and party personnel extorted what they wished. (Clapham 2018)

67 These include the quota system (whereby farmers were obliged to sell their produce to the government at a gate price lower than the market offered), levies and contribution, villagization and resettlement, and large-scale state farms (which were preferential government support in the form of access to fertile land, agricultural inputs such as fertilizer and select seeds and credit). 
The Derg regime retained an idea of Ethiopian nationalism that derived from its own revolutionary and military origins. Its very first quasi-program announced in June 1974, aptly entitled Ethiopia Tikdem (Ethiopia First), and subsequent programs including the Ten-point Program issued in December 1974 and even the 1976 NDR which accepted the principle of ethnic self-determination all asserted that the territorial unity of Ethiopia shall remain sacrosanct without ethnic, religious, linguistic or cultural differences. Plus, the constitution of the PDRE introduced in 1987, made clear that Ethiopia is a unitary state despite its provision for 'autonomous regions' in addition to ordinary administrative regions. Acceding to nationalist demands would contradict the Dergue's conception of the founding of the nation (Lefort 1983:116).

Thus, the leadership ${ }^{68}$ kept its strong commitment to the unconditional unity of Ethiopia and its authoritarian nature undermined any fundamental policy shifts regarding the question of nationalities. It refused to grant political rights to Ethiopian nationalities, and centralization was pursued with increasing brutality (Vaughan 2013; Markakis 2011; Clapham 2019; Young 1996) offering what Halliday and Molineux (1983) called "throttled 'socialist' solutions and a mailed fist".

The dramatic increase of nationalist aspirations and proliferation of armed organizations to back these up rendered multinational Ethiopia ungovernable. In

\footnotetext{
${ }^{68}$ Mengistu Haile-Mariam's own ethnicity remains uncertain, though he was most probably from an ethnic minority from the south-west. However, there can be little doubt that he was an Ethiopian nationalist, with a wholehearted commitment to national unity. (Shinn and Ofcansky 2013:286-87) With regards to other members of the Derg, Markakis writes "[A]lthough its exact ethnic composition was not known, the Dergue itself was not homogenous, and several of its prominent members were not Amhara". (Markakis 1989:124)
} 
addition to the war in Eritrea, which had been simmering since the early 1960 s, rebellions, often ethnic-based, sprouted in various regions threatening the country's unity (See table 12). Of the two dozen groups, TPLF, ALF, EPRP, EDU, IFLO, ONLF, and OLF fought with varying degrees of effectiveness to the last days of the military regime (Tareke 1991:3).

Table 12. Selected Rebel Movements in the last days of the Derg in Ethiopia

\begin{tabular}{|c|c|}
\hline ALF & $\begin{array}{l}\text { Afar Liberation Front formed in 1975; waged an armed struggle against the Derg } \\
\text { led by Sultan Ali Mirrah (Shinn \& Ofcansky 2013:24-25); supported by ELF and } \\
\text { Somalia (Shehim 1985:343) }\end{array}$ \\
\hline EPLF & $\begin{array}{l}\text { Eritrean Peoples' Liberation Front split from ELF in } 1971 \text { and was actively } \\
\text { supported by Sudan and Somalia (Tareke 2011) }\end{array}$ \\
\hline TPLF & $\begin{array}{l}\text { Tigrayan Peoples Liberation Front; formed in February 1975; aligned with EPLF } \\
\text { and supported by Sudan and Somalia (Young 1998) }\end{array}$ \\
\hline ELF & $\begin{array}{l}\text { Eritrean Liberation Front; founded in July } 1960 \text { in Cairo by veteran political } \\
\text { exiles; supported by Egypt, Sudan and several Arab regimes in the Middle East } \\
\text { ((Connell and Killion 2011:210-11) }\end{array}$ \\
\hline OLF & $\begin{array}{l}\text { Oromo Liberation Front; formed in 1974, supported by Eritrea, Sudan and } \\
\text { Somalia }\end{array}$ \\
\hline WSLF & $\begin{array}{l}\text { Western Somali Liberation Front; directly organized and supported by Somali } \\
\text { army }\end{array}$ \\
\hline SALF & $\begin{array}{l}\text { Composed of Oromo and Somali elements and fought mainly in Bale and } \\
\text { Sidamo }\end{array}$ \\
\hline ONLF & $\begin{array}{l}\text { Ogaden National Liberation Front; formed in } 1984 \text { in Kuwait; a faction of WSLF; } \\
\text { supported by Somalia and Eritrea }\end{array}$ \\
\hline BPLM & $\begin{array}{l}\text { Benishangul Peoples Liberation Movement formed in } 1989 \text { in Khartoum (Young } \\
\text { 1999:327); support from Sudan }\end{array}$ \\
\hline SLM & $\begin{array}{l}\text { Sidama Liberation Movement; formed in } 1978 \text {; waged a short unsuccessful } \\
\text { military campaign aided by Somalia }\end{array}$ \\
\hline GPDM & $\begin{array}{l}\text { Gambella Peoples Democratic Movement; formed in Sudan in } 1979 \text { (Young } \\
\text { 1999:326) and supported by the EPLF and the TPLF (Young 2007:22); engaged } \\
\text { in low level armed struggle supported by Sudan }\end{array}$ \\
\hline
\end{tabular}


The civil wars affected the regime's ability to govern internally and conduct successful regional relations externally. They also provided the chance for opportunistic intervention by neighbors and ultimately contributed to the collapse of the regime. A society so sharply divided along ethnic and religious lines will exhaust its strength and energy by internal dissensions, now open, now hidden, rather than embark on constructive efforts promoting national interests (Kebede 1999). In 1988, the Ethiopian government was obliged to seek a peace agreement with Somalia's Siad Barre, who was grappling with his own internal insurgency. In Sudan, Ethiopia was unable to influence political developments when Hasan al Bashir came to power in 1989 and aggressively supported the TPLF and the EPLF.

In challenging the Ethiopian regime these various rebel groups reduced the threat that the regime posed to successive governments in Khartoum, which were broadly aligned with the West until 1989. At various times the rebels received assistance from Sudanese governments and private citizens, but none were fully controlled by Khartoum. Nonetheless, the groups' political activities within Sudan's borders continued (above all in UNHCR camps), they opened offices in Khartoum, and they crossed back and forth to Ethiopia. The Sudanese state made no attempt to stop these activities, lacking either the capacity or the inclination to do so (Young 2007:21)

The unending wars and the concomitant demand to maintain a large military sector, the largest in Sub-Saharan Africa, debilitated the nation's economy. In order to suppress growing internal dissent, the army expanded from 41,000 soldiers in 1974 to 50000 in 1977 , to 65,000 in 1979 , and eventually to 230,000 in early 1991. Units from the 200,000-member People's Militia augmented army divisions. The ranks of the army were further swelled by conscripts through the unpopular mandatory national service program (Berhe 2017). 
The Imperial Ethiopian image of an ancient civilization and an island of stability in a sea of turbulence had been challenged by the protracted insurgency in Eritrea and peasant revolts in different parts of the country. During the Derg regime, apart from the armed activities by the TPLF and EPLF, low-level insurgencies by the Oromo, Somali, Sidama, Afar and among the people of Gambella and Benishangul exposed the weakness of the idea of a centralized Ethiopian state. (de Waal 2015) To a large part these insurgencies did not challenge the territorial control or political domination of the center and did not have significant military effect. However, their political significance should not be underestimated as:

They posed an ideological challenge to a unitary state, and that agenda returned with a vengeance in 1991, when they re-emerged to fill the political vacuum in large parts of the country following the defeat of the Dergue. The principle of national self-determination, widely if imprecisely known as ethnic federalism, was the logical outcome of this (de Waal 2015: 158-59 emphasis added).

The effects on the army of the disastrous political and economic policies of the regime are captured by Tareke (2011:166)

The causes for the demoralization and eventual defeat of the armed forces were profound, elemental, and multidimensional. They paralleled the steady impoverishment, disillusionment, and bitterness of the workers and peasants. After all, the army embodied all of society's contradictions. An overburdened peasantry that was abused by corrupt state and party apparatchiks was systematically but nonconfrontationally subverting the government's policies, from conscription to control of the economy. This political behavior was bound to have a deep impact on the army, since most of the recruits were drawn from the rural population. The army's structural weaknesses reflected wider and deeper problems of a society that was in a state of flux, uncertainty, misery, and pain. 
According to Clapham, the support that the Derg enjoyed among the peasantry of the south during the initial period of the revolution gradually vanished.

The military regime was not overthrown by Oromos, directly at least, but by a movement which was drawn from 'historic' Ethiopia, in Tigray and even Amhara; but its fall was certainly hastened by the loss of Oromo support: the conscripts of the 1980s were very different from the volunteers of 1977 , and were only too ready to desert, at which point many of them were recruited to help start the PDOs [Peoples Democratic Organizations], through which the EPRDF sought to extend its support into areas in which it had no military presence. Eventually, the Derg armies just fell apart (Clapham 2004: page).

\section{State Power under the EPRDF regime}

In 1991 the EPRDF and EPLF entered Addis Ababa and Asmara, respectively, heralding another new and radical redefinition of the political course of Ethiopia in less than a generation. Eritrea became a de facto independent state later formalized by a referendum in 1993. In Ethiopia, the EPRDF, a coalition of ethnicbased parties that represent the largest ethnic groups in Ethiopia, instituted a federal system along ethnic lines in an apparent attempt to resolve the 'nationalities question' by accommodating various ethno-linguistic groups. In a major departure from previous regimes, and in fact the rest of African countries, ethnic identity became the de jure basis for political and administrative organization to end the country's prevalent ethnic conflicts, replacing the highly centralized government that was widely viewed as oppressive, particularly by marginalized ethnic groups. 
As pointed out earlier in this chapter, land redistribution following the 1974 revolution addressed elements of the nationality question in Ethiopia. However, the military regime's concentration of power and failure to deal peacefully with ethnic based questions precipitated in its collapse and imperiled the territorial integrity of the country. The overthrow of the Derg government amounted to more than the collapse of a particular regime. It effectively signified the failure of a project of creating a modern, centralized Ethiopian state, built around strong central authority.

Table 13. Ethiopia: Population by Ethnicity

\begin{tabular}{|l|r|r|}
\hline \multicolumn{1}{|c|}{ Ethnic Group } & Population & \multicolumn{1}{c|}{ \% Share } \\
\hline Oromo & $25,363.765$ & $34.4 \%$ \\
\hline Amhara & $19,878,199$ & $27.0 \%$ \\
\hline Somali & $4,586,976$ & $6.2 \%$ \\
\hline Tigray & $4,486,513$ & $6.1 \%$ \\
\hline Sidama & $2,951,889$ & $4.0 \%$ \\
\hline Gurage & $1,859,831$ & $2.5 \%$ \\
\hline Welayta & $1,676,128$ & $2.3 \%$ \\
\hline Afar & $1,276,867$ & $1.7 \%$ \\
\hline Hadiya & $1,269,382$ & $1.7 \%$ \\
\hline Gamo & $1,104,360$ & $1.5 \%$ \\
\hline 75 other groups under 1 million \\
\hline \multicolumn{2}{|c}{ Source: Clapham (2018, citing Ethiopia Census 2007) }
\end{tabular}

The reorganization of Ethiopia along ethnic lines rested on both moral and practical grounds. Morally, a decisive break with the past was needed to liberate Ethiopia from the discriminatory centralism associated with previous regimes and deeply embedded in Ethiopia's long history. This break could in turn be achieved only by guaranteeing each nationality a level of autonomy that might ultimately extend to independence (Clapham 2018:235). At a practical level, it is predicated on the 
belief that communities respond better to mobilization from 'within,' in their own language, by their own people (Cohen 2006).

A federal system that devolves power to regional states together with a process of democratization, however imperfect, could engender a peaceful process of nation-building by advancing of the political, social, economic and cultural rights of all segments of the population, including formerly marginalized ethnic groups. Along with power sharing, federalism is a sounder alternative in diverse countries where ethno-national groups are politically mobilized, and identity is politically salient. It allows for the mobilized groups political autonomy at sub-national level while ensuring representation at federal level through the principles of self-rule and shared rule. In other words, it gives ethnic units the opportunity to influence decision-making at the center and meaningful autonomy at the sub-state level with regard to their own affairs (Lijphart, cited in Assefa 2019).

Before discussing how ethnic based federalism addressed issues of national integration and unity, a brief description of the administrative changes is in order. The Ethiopian federal system has two characteristics. First, regional states of the federal system are drawn mostly along the lines of ethnic (language) boundaries as six of the regional states (Afar, Amhara, Harari, Oromia, Somali, Tigray) are named after individual ethnic identities, while the remaining three (Benishangul-Gumuz, Gambella and Southern Ethiopia Nations Nationalities and Peoples) are multiethnic and are not identified with a single ethnic group (Megisteab 2019:67). Second, in principle, the arrangement extends to the nations, 
nationalities, and peoples the right to self-determination up to secession, a right enshrined in the 1995 constitution (FDRE 1995).

Aside from ethnic federalism, the EPRDF government followed its predecessor in its commitment to state ownership of land, and the kebele system was retained and indeed strengthened both in the cities and the countryside (Clapham 2018:42). The EPRDF's obsession with control over members of the federal state, however, belies the devolution of power to the local levels and is reminiscent of the highly centralized political culture of historical Ethiopia. The regime's drive to extend authority to the local levels increased after the 2000's and in particular after the 2005 election in which opposition parties gained significant seat in national and regional parliaments. Sub kebele institutions were formed to extend the party to the local levels ostensibly to ensure the implementation of the development policies of the government. These local institutional structures were often known as "development armies". 69 The obsession for local control was

${ }^{69}$ A recent article by Reuters gives a good account of how such a system known as "one to five" operates at the local level:

Rahmat worked for a system set up by the ruling Ethiopian People's Revolutionary Democratic Front (EPRDF) coalition in the early 2000s, officially to help implement central policies across the country of 105 million people...Stacked on top of Rahmat's kitchen cabinet in the town of Debark, $470 \mathrm{~km}$ (290 miles) north of Addis Ababa, are a dozen bulging folders detailing the lives of 150 neighbors: who has money troubles, who has HIV, who is caring for an orphan and who is hosting a stranger. The 27-year-old kept a copy of her handwritten notes and delivered duplicates to a local government office, which crunched the numbers and reported them upwards...Rahmat.. said she helped women seeking a divorce understand their rights, arranged for a fellow single mother to get a loan to start a café and ensured families had cards for subsidized staples like oil and sugar. If there were strangers in the neighborhood, she reported them to police... Rahmat was more than a neighborhood fixer. She was a loyal party member, encouraging residents to join the EPRDF and promoting its policies at monthly meetings. She was also part of a network of millions of people in cities and villages, universities and workplaces. The system was popularly called "one-to-five", because volunteers 
expressed by the higher echelon of state power including Meles Zenawi, the late

Prime Minister of Ethiopia as presented in this lengthy statement of de Waal:

The actual presence of the imperial state scarcely reached beyond towns and army garrisons: 'for the majority of Ethiopians, the state was non-existent'. This elaborate edifice was swept away, he said by a taxi drivers' strike and less than half a dozen tanks. Meles continued his critique of the Dergue, which had built vast military and administrative apparatus, but on very shaky foundations, as it lacked popular consent. People took every opportunity to escape, not least military conscripts who threw down their guns and surrendered at every opportunity. Meles concluded that while custom and fear were two useful instruments of rule, they would only be effective if the main instruments were to be the delivery of real benefits to the people, with sufficient consistency and impact that though patterns and expectations were to change. In short, governing Ethiopia demanded a project of making a different mode of governance hegemonic, in the sense (following Antonio Gramsci) of being thoroughly internalized. Hence the challenge of his government was for people to experience real state institutions, rather than merely the idea of being governed (de Waal 2015:157).

By the end of the first decade of the $21^{\text {st }}$ century, Meles declared

Unlike all previous governments our writ runs in every village. That has never happened in the history of Ethiopia. The state was distant, irrelevant. You paid tribute from time to time and if you didn't like it you rebelled. That's the history of Ethiopia. Now we have a formally structured state, there is a school in every village and clinics in every village, roads, infrastructure (cited in Dowden 2012).

\section{Reduction of conflict and violence under the FDRE}

The federal system of governance played positive role by opening political space for hitherto marginalized ethno-nationalist forces, particularly in the area of language, culture, local self-government, and the promotion of their own histories

would typically be assigned five other people to monitor. Some, like Rahmat, supervised more. (Fick 2019) 
(Fiseha 2007). Mainly, it has mitigated the ethnocultural, linguistic, and economic injustices that once steered the country into a civil war. As the previous part of this chapter stipulates, the Derg regime during its final years was confronted with several ethnic-based armed movements. Ethiopia faced the danger of disintegration with about a dozen rebel groups operating in different parts of the country including, Tigray, Eritrea, Ogaden, Afar, Sidama, Oromo, Gambella and Benishangul-Gumuz. ${ }^{70}$

Since then the number of armed groups fighting the state as well as the intensity of the fighting have declined considerably. During the three decades following Derg's collapse, the Ethiopian government, with the exception of the 1998-2000 border war with Eritrea, has not faced an armed conflict that threatened its power or existence. This is despite the continued token existence of armed groups in Somali region, Oromia, Tigray and along the Sudanese border in the Northwest. It also comes despite open support by Ethiopia's regional foe Eritrea to rebels fighting the Ethiopian regime and the presence of stateless Somalia as a security threat.

A corollary of the relative peace and stability has been the regime's success in pursuing a remarkably successful economic development agenda. The notable economic success of Ethiopia in the last two decades could not have been possible

\footnotetext{
70 The OLF and ONLF were part of the transitional conference in 1991 and had seats in the transitional council. However, both fell out with the EPRDF and went back $t$ armed struggle. The OLF has largely failed despite an attempted insurrection in 1992. The ONLF staged a dramatic attack on Chinese oil exploration facilities in 2007 gaining much publicity. However, effective counterinsurgency by the Ethiopian government managed to contain the insurgency. Almost all groups that claimed to engage in armed struggle against the EPRDF regime - including ONLF, OLF, Kefagn/Patriotic Front - had offices in Asmara.
} 
without a relative internal peace and stability. Ethiopia was able to reap the benefits of 'a peace-dividend' as the reduction in the number and destruction of civil war reduced the level of disruption of economic activity. With a powerful source of political support among historically disadvantaged peoples especially in the south, who were for the first time offered an equal status in its government (Clapham 2019:43), the regime implemented an agenda of economic transformation.

The federal system furthermore decentralized decision-making and spending powers, which in turn has helped build the capacity of local governments. This has had a key impact on the successes in all sectors, particularly in health services and education. "The relative peace ensured by accommodating ethnonational diversity through federalism, in the otherwise troubled region of the horn of Africa, has created a favorable environment for socio-economic progress" (Fisseha and Gebresellasie 2019:87).

\section{Local self-administration}

Ethnic federalism promoted the management of local governments by a local person who spoke the language and was more conversant with the local culture, instead of rule by an alien designee of the central government. Granted the designation of local officials was tightly controlled by the ruling party EPRDF, but at least minority groups had someone from the locality to govern them. The process of ethnic representation and integration was particularly felt in regions with ethno-national liberation movements. In Gambella, Feyissa argues that against the backdrop of a limited and largely failed integration of the local people during the 
imperial and Derg periods, the implementation of ethnic federalism has created a new political space and institutional design to further promote local empowerment.

Whichever criteria was used to determine the establishment of regional states, the creation of the Gambella peoples national regional state (GNPRS) appears to have been one of the most visible political steps ever taken by the Ethiopian state to integrate its historical minorities. By a sheer political fiat, Gambella was transformed from an obscure district to a regional state, resulting in a tremendous flow of financial resources from the federal government to the GNPRS, to meet the demands of the new political reality...local empowerment was reflected in the redistribution of administrative power. Well beyond the tenuous imperial co-option of local leaders and the appointment of a few local people to the regional administration during the Derg period, in post 1991 Gambella all regional administrative posts are occupied by locals (Feyissa 2006:213).

\section{Cultural recognition}

Among its major accomplishments, ethnic federalism reversed the previous regimes' approaches of cultural and linguistic assimilation of ethnic minorities. Whereas the Derg recognized the culture (and language) of ethnic minorities, the EPRDF took this a step further and allowed local administration and education in the mother tongues of different ethnic groups. Ethnic groups could be proud of and develop their language and culture (Hassen 1994). In states created by the imposition of one language over its neighbors, as is the case in Ethiopia, the state language (Amharic) "becomes both a resented symbol of external rule and a convenient lingua franca through which the different peoples of the state can communicate with one another" (Clapham year 239). According to Kymlicka $(1996: 111)$

one of the most important determinants of whether culture survives is whether the language is the language of the government, that is 
the language of public schooling, courts, parliaments et cetera. When the government decides the language of public schooling it is providing what is probably the most important form of support needed by societal culture, since it guarantees the passing on of the language and its associated tradition and conventions to the next generation. Refusing to provide public schooling in a minority language, by contrast, is almost inevitably condemning that language to ever-increasing marginalization.

Although Amharic remains the working language of the Federal government and the multi-ethnic regional states, all languages were accorded equal recognition. The hope that the development of regional and local languages can assist in redressing societal inequalities is based on the assumption that ethnicity is represented by language and that the greater expression of ethnicity through language will produce greater equity for groups of people in society (Turton 2006). The extension of the right to use one's own language in the administrative, education and court system has been one of the most popular steps taken after 1991 especially among the Oromo, the largest ethnic group in Ethiopia.

Federalism, decentralized power and conflict

One of the effects of federalism in divided societies is that it adds a layer of governance and an access point over which elite competition unfolds. In the case of Ethiopia, the decentralization of power through the federal system and the creation of a two-tier power structure (federal and regional) devolved the struggle for power which, instead of focusing on and threatening the central government, revolved around local issues. Local elites had new centers of layers of administrative power to struggle over. Since the institution of federalism, much of 
the ethnic based struggles focused on control of local resources, instead of movements to topple the central government as has happened during the Derg regime. "The federal arrangement localized ethnic politics. The regional states now have more responsibility for dealing with issues raised by their minority groups and with boundary issues with other regional states. While the federal state cannot entirely steer clear of such problems, it can remain above the fray and intervene only when necessary" (Fiseha and Gebresellasie 2019).

\section{Chapter conclusion}

I have argued in this chapter that (a) analysis of objective material capabilities is insufficient to make sense of Ethiopia's emergence as a regional power (b) it must be buttressed by an analysis of internal (domestic) level analysis, for the purpose of which neo-classical realism with its emphasis on second image variables gives a working theoretical framework (c) internally, the analysis of the state structure is essential to the conduct of foreign policy in a weak-state regional formation, where the nature of the state is contested and nation-building is incomplete (d) the consequential institution that should be analyzed is the state at the macro level and (e) any analysis of the Ethiopian state should be embedded in history with the identification of points of inflection that contributed to national cohesion.

Changes at the institutional level, the Ethiopian state to be more precise, have been instrumental in empowering the Ethiopian state and increasing its regional influence. The chapter took a historical approach, identifying critical junctures in Ethiopian recent history to trace the transformations that played a role 
to establish the Ethiopian polity on solid foundation and a more complete unity of the country. In the middle of the $19^{\text {th }}$ century Ethiopian rulers expanded the geographical reach of the central state incorporating different peoples which became the Ethiopian periphery. The 1974 revolution swept away the old order, replacing the Solomonic monarchy with a republic and military dictatorship and economically empowered theretofore marginal groups. In 1991, the military regime was replaced by a rebel group from the northernmost province of Ethiopia that instituted a radically different political and administrative system in the form of ethnic federalism, but with centralized economic planning and development strategies.

Two specific conclusions can be drawn from the foregoing discussion. First, the successive steps by regimes improved the foundation for national cohesion and a more perfect union of the Ethiopian polity. Territorial expansion into the fertile and populous regions of the south, west and eastern part augmented the economic and demographic capacity of the state enabling it to successfully negotiate European encroachment exemplified in the Adwa victory of 1896. The military regime took the radical land reform and recognized Ethiopia's ethnic and religious diversity. The current regime added political recognition to cultural recognition and made ethnicity the basis for the current federal system.

Second, these positive changes in governance have been accompanied by challenges in the form of unintended consequences. The relationship between the successes and challenges of the what the critical junctures have brought to the polity has taken the form of dialectics. Territorial expansion created the modern 
Ethiopian state and increased the material resources essential to the preservation of Ethiopia's independence. It also transformed a relatively homogenous historical Abyssinia into an ethnically and religiously heterogenous country, complicating the nation-building process. As a result, the challenges in the foundation of the modern Ethiopian state reverberate to the current time period.

Nationalization of rural land and recognition of the multi-ethnic nature of Ethiopia by the military regime eliminated the economic and cultural basis of ethnic domination. However, the regime continued the single nation state model assuming that once the model was stripped of some of its explicit cultural (orthodox Christianity and the monarchical system) and class character (by abolishing a highly unequal system of land tenure) a reformulated Ethiopian nationalism could be extended to the whole country. By the end, ethno-national movements proliferated, imperiling the territorial integrity of the country.

One of those movements, the EPRDF, took control of power in 1991. In a reversal of the approaches by previous regimes, it not only acknowledged the existence of ethnicities, but made ethnic identity the cornerstone of political administrative system and political mobilization. A federal system based on ethnolinguistic territorial division diffused secessionist tendencies among minorities and facilitated local self-administration and representation at the center. However, it also politicized ethnic consciousness with two implications. First, although no armed insurgency posed a threat to the central state, localized ethnic conflict increased especially in the multi-ethnic regions of the federation - BenishangulGumuz, SNNPR, and Gambella - and border disputes between various regions 
(Somali - Afar, Oromia - Somali, Oromia - SNNPR, Oromia - Amhara, Oromia Benishangul-Gumuz, and Amhara - Tigray). Although some view this as failure of the federal experiment, other view it differently.

Problems identified in different regions have been characterized as problem of success as they arise from the extent to which local peoples have indeed become responsible for their welfare, generating in the process level of participation that would have been inconceivable under any previous dispensation. The disputes within Gambella between highlanders and lowlanders on the one hand, and between Anywaa and Nuer among the lowlanders, on the other, could never have occurred in a system that ascribed all power to highlanders as a matter of course. The numerous conflicts within the SNNPRS over the demarcation of boundaries between the territories of its different constituent peoples, as well as those especially between SNNPRS and Oromia, demonstrate that these territories do matter to their peoples in a way that the arbitrary division of these areas by the government in Addis Ababa ... never did (Clapham 2017:238).

Second, EPRDF's tight control of the regional governments and the prevailing democratic deficit increased popular antipathy towards the regime. The relative peace and stability facilitated economic development. But the perception and reality of unequal power relationship within the front ${ }^{71}$ entailed a concentration of the fruits of economic success in the hands of the dominant party within the EPRDF. In the words of Young and Tadesse (2003:398), the "political and administrative weaknesses of many of these parties and the regional governments they control forced the TPLF to become more involved in their affairs than was politically desirable, thus furthering the widespread view that Tigrayans dominate every facet of government throughout the country, belying their own commitment

\footnotetext{
71 The TPLF and the oldest and most dominant member of the front and the others were created at its auspices.
} 
to ethnic federalism". A major challenge facing Ethiopia will be a peaceful transition to pluralist democracy and an actual devolution of power which would possibly lead to different, opposing parties holding power in the federal and state levels. This would surely have implications for internal peace and security, economic development and the conduct of foreign policy in the Horn of Africa.

To understand the implications of these critical junctures in Ethiopia's history to Ethiopia's regional policy, its emergence as a regional power in particular, requires going back to the idea that, in a weak-state regional system as in the Horn, internal cohesion and state strength are essential to external power projection. Ethnic insurgencies have been a near constant feature of Ethiopia's history, and managing them has been a key priority for successive leaders. To that end, they have tried a variety of tactics, from reconciliation to repression. But neighboring states have seized on the issue and supported several of these ethnic insurgencies to keep Ethiopia's attention on its domestic problems rather than on regional activities. Similarly, Ethiopia has supported insurgencies against its neighbors. Recent strategic overtures suggest Ethiopia has been able to project more influence in the region. To do so, however, the country needed to maintain internal cohesion. Critical junctures in recent Ethiopian history - nationalization of land and recognition of ethnic diversity - have assisted such cohesion. Hence the linkage between national level changes to conduct of external relations. 


\section{National Identity as a factor in Regional Standing}

The previous two chapters analyzed material capabilities and historical institutional factors to explain of Ethiopia's regional prominence in the horn of Africa. Chapter three showed that in terms of material capabilities, Ethiopia has shown significant improvement in economic capacity measured by GDP, now on par with Kenya and Sudan. The previous chapter using historical institutionalism looked at the evolution of the Ethiopian state as it reached critical junctures in regime transitions as having contributed to its influence in the horn of Africa. This chapter shifts the attention to the ideational sources of Ethiopia's regional powerhood. Specifically, it explores the extent to which national identity as a function of ideational factors buttresses Ethiopia's quest for regional prominence in the Horn of Africa. It is predicated on the conjecture that Ethiopia has a "usable past" or history that serves as a source of national identity which successive governments have tapped as a tool in their foreign relations. Ethiopia's history as an independent and uninterrupted nation to support strong foreign regional policy.

Since its emergence in the behavioral social sciences in the 1960's, the concept of "national identity" has gained increasing prominence. In international relations, national identity has gained currency in particular due to the prominence of constructivist theories. Contemporary Countries with regional (or global) aspirations such as China, Iran, Egypt, and Turkey embody old civilizations that they can and have tapped as a source of their aspirations for power. In this sense, 
this chapter aims to demonstrate that Ethiopia reflects such old civilization and recent history that regimes have appealed to for foreign policy objectives.

The study of national identity as an instrument of foreign relations goes beyond traditional military and economic capacities. The study of Ethiopian history has long made a claim to exceptionalism based on the country's many distinctive features: the cradle of humankind, a statehood with roots that go back to antiquity, a literate culture with its own alphabet and a unique system of calendar, the only place in Africa where Christianity survived as a native faith, home to ancient civilization in the Axumite kingdom, one of the first destinations of the two other Abrahamic religions, Judaism and Islam, a surplus producing agrarian economy that sustained a sophisticated class-stratified society, and the unique confrontation with and triumph over European imperialism in the nineteenth century (Markakis 2020; Tibebu 1995).

\section{Aspects of Ethiopian national identity}

Ethiopian national identity exhibits two predominant elements. ${ }^{72}$ The first one is the contested nature of the concept of Ethiopianness and what it means to be

\footnotetext{
72 Teshale Tibebu (2015) identifies at least six different, and often competing, images of Ethiopia: (a) Christian Ethiopia projected by the Axumite paradigm of Ethiopian historiography depicting Ethiopia as "a Christian island surrounded by heathen sea"; (b) Semitic Ethiopia an Orientalist/Semitic paradigm in which Ethiopia seen as a SemiticChristian nation; (c) the Ancient African Ethiopia projected by the pan-African paradigm of Ethiopia as "the rock of black resistance against white invasion"; (d) the black colonial power Ethiopia, an image projected by the ethno-nationalist paradigm of Ethiopian history which postulates that Ethiopia was the only African country that participated in the colonial scramble of Africa by taking control of many peoples during the expansion of the $19^{\text {th }}$ century; (e) Ethiopia with its own triple heritage proposed by Ali Mazrui that
} 
Ethiopian. Broadly speaking there are two strands of understanding Ethiopian identity. On the one hand is the romanticized version of Ethiopia as a beacon of freedom and anti-colonialism, the beacon of pan-Africanism and anti-colonial struggle by African countries. In contrast to this image Ethiopia is seen as a participant in the colonial scramble of Africa. Per this view, Menelik's territorial expansion to the South is tantamount to colonialism. The image of Ethiopianness that emanated from this expansion is that of the dominant Abyssinian identity imposed in the subaltern peoples of the South.

A second element of Ethiopian identity is its dynamic nature. In his book, Identity: The Demand for Dignity and the Politics of Resentment Francis Fukuyama states that national identity is built by following one or more of four major paths. The first is occupying another territory through settlement, eviction or killing of natives. The second is adjusting borders based on existing linguistics or cultural similitude. The third is by assimilating a minority into an existing ethnic or linguistic group. The fourth is by reshaping national identity into the existing characteristics of the society. A cursory look at these alternative paths and the discussion of critical junctures in the preceding chapter shows the understanding of Ethiopianness has evolved through most of these paths. Contemporary Ethiopia was formed through territorial expansion and settlement. Although territorial expansion created a highly diverse Ethiopia, initial approaches to national identity

Ethiopia has its own triple heritage namely indigenous, Semitic and Greco-Roman; ( $f$ ) Feudal Ethiopia an image projected by a Marxist or a Modernist paradigm which claims that Ethiopia is a feudal state akin to those in medieval Europe and needs a radical social revolution to experience progress. 
were exclusionist and imposed a dominant Abyssinian culture. However, social revolutions that followed critical junctures (1974 and 1991) have created the opportunity to redefine Ethiopian identity into a more inclusive and representative of the new reality.

In the wake of the incursion into Ethiopia by Somalia's troops in 1977 and Eritrea's soldiers in 1998, several issues come clearer. First was that it is undeniable that national identity, even in reformed form, remains a strong tool to mobilize the population in Ethiopia. Second, even with appeal to national identity, some reform of policy, in the form of land to the tiller in 1977 and ethnic federalism in 1998, matter. Third, also important is the state's capacity to control the local level to coerce local level administrations in addition to appeal to identity and policy changes. (Tronvoll 2009)

Of all these axioms of Ethiopian exceptionalism, the enduring history of statehood uninterrupted by European colonialism is the most consequential for national identity and foreign policy. In particular, this chapter on Ethiopian national identity will concentrate on the 1896 victory at Adwa over Italian invasion as (a) it was instrumental in preserving Ethiopia's independence (b) it is an outcome of international interaction (c) it has been instrumental in informing Ethiopia's conduct of regional foreign policy.

Historically, war has played a crucial role in the shaping of national identity. The historian Michael Howard has claimed that "[N]o Nation, in the true sense of the word, could be born without war," and "no self-conscious community could establish itself as a new and independent actor on the world scene without an armed conflict or the threat of one" (Howard 1979:108). Ethiopia is no exception in this regard. Adwa is among several wars that Ethiopia fought with invading armies, 
including at Maqdala (1868) against the Napier expedition force of Great Britain; Gundet (1874) and Gura (1876) against Egypt; and Dogali (1888) against Italy. However, the Italian defeat at the battle of Adwa, "the greatest single disaster in European colonial history" (Mockler, quoted in Tibebu 1996), sent shock waves throughout the world. The victory at Adwa echoed throughout Europe: an indigenous, black army had won a decisive battle against a European colonizer. It was the bloodiest of all colonial battles, leaving between 10,000 and 13,000 dead on each side (Milkias 2005). The European press flashed headlines like 'The Italians have suffered a great disaster ... greater than has ever occurred in modern times to white men in Africa' (Prouty 1986:159).

In the wake of Ethiopia's victory against Italy in the battle of Adwa 1896, her nationhood was fortified by a series of changes: a national system of secular schools; a national bank and postal system; a national network roads; a standing national army; an effective and prestigious national airline; and a number of cultural forms that gave expression to a modern Ethiopian national culture in such areas as athletics, literature, music, and the visual arts. Through these changes and the majesty of two powerful emperors, Ethiopia was well on the way to becoming a successful, independent nation- state in the twentieth century. Ethiopia proudly took its place among other sovereign states by joining the League of Nations in 1923. It played prominent role in the United Nations as a founding member and a staunch supporter of UN collective security and other UN missions. Thanks to historic role as a symbol of African freedom and the mediations of its skillful emperor, the regime became recognized as a major player during the decade of African independence of the 1960s. Addis Ababa was host for the United Nations Economic Commission for Africa. (Levine 2011:312)

The battle of Adwa is considered "the most important event serving as a point of reference for Ethiopian identity in modern history" (Tronvoll 2009:39). In addition to forming the center of Ethiopian identity, Adwa became the foundation of African 
identity and the pan-African movement to Africans on the continent and among blacks in diaspora.

...Africans have taken Ethiopia as the most beloved of their possessions, as the jewel and pride of Africa-indeed, of people of African descent...the pan-African construction of Ethiopian identity not only includes Ethiopia as part of Africa but made Ethiopia the quintessence of Africa. Ethiopia became the concentrated expression of Africa. Ethiopia carried the burden and suffering that was Africa. Ethiopia symbolized the hope and pride of Africa. The biblical Ethiopia "stretching its hands unto God" became the real Ethiopia invaded by Mussolini. It was in the historical context of Mussolini's invasion, and earlier the Ethiopian victory at Adwa, that the pan-African construction of the Ethiopian identity was formed. It was the feeling that the pride of Adwa, the pride of Africa, was to be erased by the second coming of Italy that galvanized a passionate pan-African defense of Ethiopia. Ethiopia has a unique place in the consciousness of Africans. It has been revered as the symbol of Black defiance of White domination. From London to Harlem, from Lagos to Kingston, from Accra to Cairo, the Italian fascist invasion of Ethiopia became a rallying ground of pan-African nationalism. (Tibebu 1995:420)

\section{Implications of Adwa for Ethiopia's national identity}

The Adwa victory had impacted Ethiopia's foreign relations in several ways. First, in its immediate aftermath the Ethiopian government engaged in an active diplomatic relationship with the outside world. Subsequent to Adwa, European powers with adjacent territories in East Africa concluded treaties to recognize the independence and sovereignty of Ethiopia. Britain, Italy, and France univocally recognized Ethiopia and within months sent delegations to Addis Ababa to sign treaties. Ethiopia's international state boundaries were gradually defined in treaties with France (1897), with Britain (1897, 1900 and 1902) and with Italy (1902 and 
1908). As a result, Ethiopia obtained de jure recognition in the international system of nation states.

A second implication of Adwa with regards to Ethiopian conduct of foreign policy is the institutionalization of its foreign relations. Following the treaties, Menelik initiated a process of modernization of the state and government. A Ministry of Foreign Affairs was one of a ministerial cabinet that was formed in 1906. After thousands of years as an independent African country, Ethiopia has a long diplomatic history and rich experience in foreign relations (Smidt and Abraham 2007). However, the creation of a foreign ministry institutionalized the practice of foreign relations. The Ministry remained operational except during the Italian occupation of 1936-41. The Ministry established a strong diplomatic culture and practice.

Corollary to the institutionalization of foreign relations, the maintenance of independence allowed an autonomous foreign policy manifested by Ethiopia's membership in international organizations. Ethiopia joined the League of Nations in 1923 and it was a founding member of the UN in 1945. The UN-ECA was set up by the United Nations in 1959 in Addis Ababa. Ethiopia's prestige as a beacon of independence in Africa was crowned with the decision by African heads of states and government to headquarter the OAU in Addis Ababa in 1963. The formation of the OAU was seen as the culmination of Pan-Africanism which had been inspired by the anti-colonial victory of Ethiopia. Being a member of an international organizations comes with its own advantages including the international respect and recognition that comes with Ethiopia's troop contribution to the UN 
peacekeeping missions in Korea (1951) and Congo (1962), a practice that expanded in the post-cold war period.

\section{Adwa - Mobilization of National Identity in war}

The activation of national identity as a political resource is specific to certain situations. Specifically, threats to and opportunities for the enhancement of security often function as incentives for the mobilization of national identity. In this respect, wars serve as the ideal catalysts to the activation of national identity. In Ethiopia the monarchy, the military and the EPRDF regimes tapped the victory of Adwa during times of military conflict. When Italy used a minor incident at Walwal in Eastern Ethiopia as a pretext to invade Ethiopia in 1934, nationalistic sentiments among Ethiopian political and intellectual leaders instantly escalated. References to Adwa were used to mobilize the population to a second round of invasion by Italy. subsequent to the impending Italian invasion,

various articles were put out in the newspapers. These articles largely emphasized on [sic?] the values of liberation, patriotism and heroism. They reported that the independence handed down to this generation had to be defended. Although these articles dealt with the patriotism and heroism that the Ethiopian people were endowed with, it can be commented, however, that they implicitly referred to the Victory of Adwa. As opposed to the earlier times when narrations of the Victory of Adwa were not published, articles were published recounting regarding the Victory of Adwa. The writers, to encourage the people, drew lessons from the Victory of Adwa. One article read, "Italians are no different; their heart is similar; only their gun is new". (Woldegabriel 2004:21)

However, "each ruling elite appropriates the past from its perspective and narrates

it as the collective memory of the people. Each interpretation tries to establish a 
hegemony over the collective memory of the people, and each is subjected to differing interpretations by opponents." (Mennasemay 2005) Ethiopian nationalism and national identity during the imperial reign was a dominant ethnic-based nationalism, in which the state was draped in expressions of Amhara (Abyssinian) culture, symbols and religion. Thus, subaltern identities were subjugated to a dominant national identity. (Tronvoll 2009) Even the celebration of Adwa, although it a national holiday, signified the Orthodox Christian nature of the event as it took place inside the compound of St. George Church until the 1974 revolution. (Woldegabriel 2004)

The military regime initially evinced ambivalence about the history of Ethiopia and the nature of Ethiopian identity in particular. On the one hand, it came to power as a result of a popular revolution that rejected the feudal regime and the monarchy which had hitherto been the symbol of national identity and unity. The new people in power were also critical of millennia of feudal backwardness and the hierarchical system it engendered. Plus, the Derg gradually adopted a radical Marxist ideology which contravened the feudal legacy. However, the Derg was also a deeply nationalistic regime and the anti-colonial history of Ethiopia naturally appealed to its nationalistic predilections. Soon, Adwa was detached from its religious meanings and was celebrated as a secular holiday in public squares (at Menilik square and/or revolutions square). The celebrations became the showing of Ethiopian anti-colonial struggle.

As with the imperial regime, war brought the use of national identity to the fore. During the incursion by Somalia into Eastern Ethiopia in 1977, the Derg was 
fighting not only the Somali invading army but also the right-wing movement (EDU), ethnonational rebellions (EPLF, EPLF, and ELF) and clandestine groups of the civilian left (EPRP and MEISONE). Adwa became a rallying call to save the motherland from invasion and disintegration. In this regard the 1978 Adwa day celebrations were a case in point at a time Sudan expanded its support to rebels in Ethiopia and Somalia declared war on Ethiopia.

In his speech delivered to the large rally at Menelik Square and to the Ethiopian people in a nationwide address, Colonel Mangistu [sic?] said: "... just as the broad masses of Ethiopia won the historic Victory of Adwa which heralded a ray of freedom for the whole of Africa, the time is fast approaching when this generation will be performing a startling show against the enemies of the country and its Revolution by re-enacting Adwa through the crushing blow..." (Woldegabriel 2004:45; emphasis added)

Owing to its Socialist ideology, however the Derg highlighted Adwa's antiImperialist nature. Adwa was portrayed as a struggle by and victory for all peace loving and depressed nations of the world. In subsequent speeches and celebrations, Mengistu and the military regime equated Adwa with the struggle for anticolonialism by African countries (Angola, Zimbabwe), against apartheid (south Africa) and against imperialist US intervention (Guatemala, Vietnam). In 1980, Mengistu reiterated the same point:

The Victory of Adwa ,which was a great witness to and historical proof of the fact that dictators and imperialists cannot withstand the united mighty [sic?] of the oppressed working class, should not be regarded as a triumph for Ethiopia heroes alone... is shared by all peace loving and militant people of the world because it demonstrated that oppressed working peoples with lofty goals and united will are capable of making expansionists and dictators taste the bitter choice of defeat." 
When the EPRDF came to power in 1991, many doubted its nationalist credentials and went as far as claiming the front as anti-Ethiopian for several reasons. First, the EPRDF was the child of the radical student movement of the 1960's that embraced the Stalinist definition and theory of the national questions; this doctrine accepted the rights of nations and nationalities for self-determination. Second, the front was organized along ethnonationalist lines and in its formative years espoused an independent Tigray republic. Third, it recognized the multi-ethnic nature of Ethiopia and made ethnicity the lynchpin of the new federal administrative system. For Ethiopian nationalists, the ethnicization of politics "is a deliberate ploy to undermine national identity, pride and self-esteem flowing from the exceptional history and continuity of the Abyssinian empire and Ethiopian state. They see the constitutional granting of self-determination to ethnic groups as a deliberate step backward from the nation- building process." (Mennasemay 2005) Fourth, the EPRDF readily accepted Eritrea's independence, maintained tactical alliance during the military struggle against the military regime and forged close ties with Asmara until the war broke out in 1998.

However, the new leaders soon embraced Ethiopian nationalistic sentiment, especially the long-standing pride in independence. This was first manifested in the centenary celebrations of Adwa in 1996 five years after the EPRDF came to power. Similar to previous regimes, the place of Adwa for Ethiopia's independence and territorial integrity was recognized. Similar to the Derg's confrontation with Somalia, an opportunity to accentuate Ethiopia's history of independence came during the 1998-2000 war with Eritrea. During the war, 
Adwa was used to mobilize the Ethiopian people against an aggressor. Almost surely by design, the 1999 military campaign to liberate the small town of Badme, the flashpoint of the war, coincided with the Adwa celebration. The 103 Adwa commemoration on March 1, 1999 which came right after the liberation of Badme on February 28 drew a large crowd at Meskel square for a spontaneous celebration and expression of support for Ethiopian troops. The residents of Addis Ababa were chanting 'Badme - Adwa, Adwa - Badme', 'Adwa is not only history but is always viable', 'Adwa is a covenant which the Ethiopian people showed once again against Isayas' (Woldegabriel 2004). The successful campaign was coined as the second Adwa.

This fluid counter-memory of Adwa - secretly nourished over the years and preserved both within Ethiopia's multi-layered society and in post-liberation Eritrea -flared up during the border conflict (19982000)...The conflict...was often portrayed in Ethiopia as a replay of the attacks Italy had staged from neighbouring Eritrea in both the liberal and Fascist years. In February 1999, when the Eritrean troops were routed near the village of Badme, along the Tigray-Eritrea border, the Battle of Badme was promptly labelled 'the second Adwa'...Adwa secured the country's independent status throughout the colonial scramble for Africa. Moreover, it became the battle of legends and myths of Ethiopian heroism and nationalism. So much so that the victorious battle of Badme (not very far from Adwa) which came to an end on 1 March 1999 - where Ethiopian forces drove the Eritrean army off Ethiopian soil at a cost maybe ten times higher than Menelik's losses - was instantly termed the 'Second Adwa'....More importantly, though, the Adwa victory has thenceforth been used to forge an all-embracing sense of Ethiopian identity, contrasted with 'foreigners' of all kinds who interfere and meddle in Ethiopian affairs. (Tronvoll 2009)

Due to the dominant political discourse of the era or regime, Adwa was now construed as a struggle of Ethiopia's nations and nationalities against a foreign 
aggressor. It was presented as a multi-ethnic project and mobilization, paying less attention to leaders such as Menilik who are perceived by many in southern Ethiopia as oppressors and expansion of the Ethiopia polity. During a speech at the centenary celebration of Adwa in 1996, Dr. Negaso Gidada, then the President of Ethiopia, remarked

Although the expansionist campaigns carried out in our midst by Emperor Menelik which, resulted in the suppression and annihilation of the various peoples, not to mention the spread of national oppression and humiliation, was the identifying feature of the Emperor's rule, the role he played in organizing and leading the people in the defensive war against the invading Italian army cannot be left unmentioned. (Woldegabriel 2004:)

\section{Chapter conclusion}

This chapter turned the attention to national identity, a national level factor, to explore the role of Ethiopia's strong sense of national identity and usable past in its' rise as a regional power. Among the many foundations of national identity, the chapter focused on the maintenance of the country's independence and the anticolonial struggle embodied in the Adwa victory against Italy. The Adwa victory ensured Ethiopia's international recognition. In addition, Adwa, and the survival of Ethiopia's independence more generally, is a theme that recurs in the conduct of Ethiopia's external relations. Their ideological differences notwithstanding, successive regimes have strategically deployed Ethiopia's anticolonial struggle as an aspect of national identity in the conduct of foreign relation as exemplified in war (with Somalia 1977 and Eritrea 1998) and in economic action (the construction of GERD as discussed in Chapter 2). 


\section{Summary and Conclusion}

This dissertation was broadly divided into two parts. Chapters 2 and 3 strongly made the case that Ethiopia is a regional power. In chapter 2, I used bi-lateral relations with Somalia and Eritrea to demonstrate Ethiopia's growing regional influence. In Somalia Ethiopia has been actively engaged diplomatically and militarily. Ethiopia's diplomatic effort was to restore a central government since the collapse of central authority in 1991. Ethiopia's interest in Somalia has revolved around four imperatives (a) to restore a centralized government with a friendly regime at the helm that does not revive Somalia's claim to the Ogaden region of east Ethiopia (b) to ensure Somalia does not become safe haven for Ethiopian insurgent groups (c) to ensure Eritrea and broadly Egypt does not become too influential in Somali politics and (d) to preempt the rise of Islamic threat in the form of armed groups (al-Ittihaad) or a centralized authority (UIC). Ethiopia succeeded in objectives b, $c$ and d. However, centralizing state power in the hands of a friendly regime has proved to be a challenge. Therefore, Ethiopia had to settle for a suboptimal outcome, but its record demonstrates its regional power status.

Eritrea and Ethiopia formed a cordial relationship after the latter's independence in 1993 after a liberation struggle that lasted for three decades. However, they were mired in an unexpected and bitter war from 1998 to 2000 . The foreign policy objectives of Ethiopia vis-à-vis Eritrea since has been to (a) regain

control of Ethiopian territories (b) limit Eritrea's effort to undermine Ethiopia regionally by supporting Ethiopian insurgencies or groups in Somalia opposed to 
Ethiopia (c) ensure Eritrea's diplomatic isolation regionally. Akin to the goals with Somalia, Ethiopia succeeded in military victory to regain its territories and diplomatically isolate Eritrea and limit Eritrea's influence in Somalia. However, the regime in Asmara survives to this day and much of the territories Ethiopia recaptured were awarded to Eritrea by the EEBC, a ruling that has not been implemented. Similar to its Somalia efforts, Ethiopia's success in Eritrea has been qualified.

Chapter 3 extended my contention that Ethiopia is a regional power by looking into projection of interest and values, provision of public goods and perception of regional dominance. To analyze projection of interest in the region, I looked at the cases of Eritrea and Somalia mainly and, as stated above, Ethiopia's objectives have been largely successful. With regards to the export of values, Ethiopia promoted the adoption of a federal system in Somalia by using clan identity as a basis for territorial division and representation at the central level. Ethiopia had already adopted an ethnic-based federal system in 1995 and believed the formula could work in other countries in the region as well. However, certain groups saw Ethiopia's push for a federal system a ploy to weaken the central state and ensure Somalia will remain a weak and divided neighbor unable to pose a threat to Ethiopia. On the subject of provision of public goods, I discussed two elements - economic and security. No country in the region is economically preponderant enough to provide economic goods in the form of preferred access to its markets, act as a lender of last resort, or create a liberal regional economic system. 
This dissertation showed, however, that Ethiopia does have the ambition to be a hub for regional economic integration manifested in its energy diplomacy. While ambition demonstrates awareness and willingness to play prominent role in the region, it does not entail current predominance. Concerning security, Ethiopia's role is expressed through UN-PKOs. Apart being one of the largest contributors of troops and police to PKOs, Ethiopia currently has presence in Darfur, Abiyei (between South Sudan and Sudan) and Somalia. Active participation in PKOs translates into regional and? international diplomatic recognition. In addition, Ethiopia has created a sphere of influence through its troops in AMISOM deployed in areas close to the Ethiopia-Somalia border. Apart from projection of interest and provision of goods, regional powers also perceive their regional dominance. The official line of the Ethiopian government is that it does not aim to be a regional hegemon. But as documents have shown, there is a growing awareness among the ruling party and government of Ethiopia's predominant role. Like other regional powers, Ethiopia both acknowledges its regional standing, but also downplays that standing in order to reassure its neighbors of benign intent. Empirically observed behavior also substantiates the contention that Ethiopia's political class embraces as the role of regional power.

The second part of the dissertation (chapters 4, 5 and 6 ) turned the attention to identifying the explanatory factors for this phenomenon. Chapter 3 used distribution of military capability among countries in the region to probe whether Ethiopia's dominance emanates from uneven control of capabilities. Specifically, population size, economy capacity (GDP) and military force (personnel and military 
expenditure) were analyzed. Ethiopia has the second largest population in SubSaharan Africa and the largest in the Horn. Economically, 2015 data shows that Ethiopia's share of the region's GDP (28 percent) equals Sudan's and is slightly higher than that of Kenya's (24 percent). The three countries are the economic powerhouses in the region. Although Ethiopia has registered impressive economic growth tripling its GDP in a span of 10 years, its economic dominance is more potential than actual. As regards military power, Eritrea leads the region in the number of troops while Sudan has the highest military expenditure and the best weapons. Thus, Ethiopia's regional prominence does not appear to result from its superior material capabilities.

Chapter 5 therefore turns the focus to the national level. The turn towards domestic level explanation draws from neo-classical realism which accepts the realist tenet that power is central to the conduct of politics, but it should be supplemented by domestic level variables. The turn towards the domestic is particularly essential for Africa. First, sub-regional interstate systems in Africa are composed of weak states whose nation (state) building is incomplete. Second, sub-national actors including armed rebels, religious and ethnic communities, NGOs play prominent role in the conduct of foreign relations. I used historical institutionalism to identify historical inflection points in the evolution of the Ethiopian state that contributed to nation building predicated on the contention that, for decades, the region has been characterized by proxy wars and the export of internal instability by countries like Ethiopia, Somalia, and Sudan. Reversing this historical pattern requires policies that foster state cohesion. Ethiopia has become 
a regional power as a result of revolutionary changes that followed critical junctures. These changes enhanced state power by creating stronger connections between the population and the state. Centralization of the state and territorial expansion in the middle of the $19^{\text {th }}$ century augmented the resources available to the state. Distribution of land though land to the tiller proclamation in the wake of the 1974 revolution diffused ethnic tensions that imperiled the country.

More recently, the institution of ethnic federalism by the current regime has resolved a key challenge in Ethiopian nation building. The resolution of ethnic tension is exemplified by the near total control the Ethiopian state enjoys throughout the territory and the near absence of any armed opposition that challenges the central government or open chances for foreign intervention. This is in stark contrast to the final years of the Derg which faced multiple ethnonational based insurgencies (see table 12) supported by countries in the region. Faced with these armed movements the Derg could not pursue an active regional relation. The extension of state power to all parts of Ethiopian territory and the exercise of total internal control has had implications for regional policy. First, the Ethiopian regime could concentrate its resources on economic development which buttressed its regional ambitions. Economic growth could support an ambitious regional policy; it also necessitated a peaceful region and regional integration. Second, in the absence of active rebel groups, the regime was less susceptible to intervention from external challengers. This is not for lack of trying. Eritrea in particular has openly harbored armed Ethiopian rebels. Third, internal 
incorporation also meant that the Ethiopian government could pursue an ambitious policy of intervention without the risk of internal revolt?

Chapter 6 grappled with national identity, another national level factor, to explain Ethiopia's' emergence as a regional power. The main argument is that Ethiopia has a strong sense of national identity and a usable past that regimes rely on as an instrument of foreign policy. Among the many sources of Ethiopian national identity, I focused on the maintenance of the country's independence and the anti-colonial struggle embodied in the victory against Italy at Adwa in 1896 because (a) it is an aspect of international relations, (b) it ensured international recognition to Ethiopia and (c) Adwa and the survival of Ethiopia's independence is a common theme in the conduct of Ethiopia's foreign policy. The chapter concluded that different regimes deployed Ethiopia's anticolonial struggle to fit their ideological predilection. Nonetheless, appeal to national identity has remained a common feature of successive regimes and has been strategically deployed in the conduct of foreign relation as exemplified in war (with Somalia 1977 and Eritrea 1998) and in economic action (the construction of GERD).

\section{Theoretical relevance}

In the literature on regional powers, various scholars disagree on this question of how regional powers become regional powers. Is it because they simply have more (military and economic) power than all of their neighbors (as neo-realism might suggest, when applied to regional settings)? Or, is it because they have been recognized as regional powers by all of their neighbors (as constructivists might argue)? Or, is it due to domestic level variables that intervene between a state's 
material attributes and its foreign policy (as neo-classical realism argues)? In short: how is it that regional powers become regional powers?

This dissertation tests a hypothesis that might come out of neo-classical realism on this debate among scholars of regional powerhood. Neo-classical realists recognized that relative power (vis a vis the neighbors) is a key to understanding both regional political standing and foreign policy. Relative power in and of itself, however, does not fully explain the rise of a regional power. Therefore, NCR scholars insist that you must look inside of states to determine what the sources of their power vis à vis their neighbors. This is especially true in a weak-states regional system such as the Horn of Africa where national borders are contested, nation-building projects are unfinished, and cross-border intervention in support of insurgencies is prevalent. So, this dissertation looked inside of Ethiopia to try to determine why it is relatively strong compared to its neighbors. Here is what the dissertation found: (1) Institutions evolved in Ethiopia through a kind of "punctuated equilibrium" marked by a series of critical junctures; events following each of these critical junctures served to (a) expand the Ethiopian identity from an Abyssinian heartland to a larger community and (b) connect the people of Ethiopian more and more strongly with the central state over time. The 1974 revolution and subsequent land proclamation of 1975 addressed the material basis for ethnic domination. The 1991/95 ethnic federal system solved cultural oppression and paved the way for local self-administration, under tight control by a dominant party. 
This process was paradoxical in the second stage: groups outside the Abyssinian core are simultaneously enjoined to both (i) celebrate their ethnic uniqueness and exercise their community political rights but (ii) demonstrate their loyalty to the central Ethiopian state by supporting its drive for national development and supporting its foreign policy goals. (2) Ethiopian leaders have cleverly created a sense of national identity by constantly referencing Ethiopia's heroic past as the only Africa state that successfully resisted European colonialism. They have even convinced ethnic groups outside the Abyssinian core that they, too, reflect the glory of Ethiopia's victory against Italy at Adwa. Ethiopian leaders have made their state powerful by connecting all of the various ethnicities of Ethiopia to projects of the state. By looking inside of Ethiopia, I have understood the source of its regional powerhood.

The theoretical shift to national level institutional transformation and critical junctures to explain foreign policy could be extended to other sub-regional powers - actual and potential - in Africa. In the case of West Africa, Nigeria's transition from military rule to civilian democracy can be explored. In southern Africa the end of Apartheid has freed South Africa from international isolation and post-Apartheid South Africa has strong presence in continental and international fora. In Central Africa, the DRC has the attributes to emerge as a regional power - geographic and demographic size and resource endowment. However, the postindependence state has been too weak to assert control internally mush less project its power regionally. Domestic level analysis informed by neo-classical realism therefore can be a useful analytical tool for the foreign relations of Africa. 


\section{Policy Relevance}

Ethiopia's status as a regional power is based on its position relative to other neighboring countries in the Horn of Africa, its military interventions in many of those countries, its relatively large population and economy, and the historical role it has played in promoting continental unity, including acting as the headquarters for the AU. The political class of Ethiopia recognizes that regionally the Horn of Africa has gone through a different pattern of sate formation than other parts of Africa mainly due to preservation of Ethiopia's independence and territorial expansion of the Abyssinian core to the south. As a result, Ethiopia is viewed as having taken part in a scramble for Africa. Eritrean liberation movements portrayed Ethiopia as colonizer and the construction of Eritrean identity is interlinked with the liberation struggle against the colonial other. Somalia's regimes also called for the self-determination for the people of Ogaden. The conduct of Ethiopia's regional relations is consequently met with suspicion and resistance by countries in the region. Ethiopia's leaders should present regional policy, such as energy projects and regional economic initiatives, as mutually beneficial. Ethiopia needs to seize its rising responsibility and use its capability and capacity with care and with the strategic interests of the whole of the Horn of Africa in mind.

Another aspect that the Ethiopian leaders should understand is that becoming a regional power is neither irreversible nor preordained. Ethiopia's rise as a regional power is a result of focus on internal challenges of democracy (in terms of ethnic diversity) and economic development. Ethiopian leaders should understand that sustaining this emphasis on the internal challenges should 
precede external policy and strategy. Recognition of past achievements for resolution of national challenges, fostering national cohesion and boosting national power for effective foreign policy are essential. However, it should be grounded in the understanding that challenges have appeared as unintended consequences. The ethnicization of politics has democratized politics and recognized diversity as a source of power. However, concentration of power by the ruling party EPRDF belied the deconcentration of power through ethnic federalism. The perception that the EPRDF is dominated by minority group from the north would weaken the country. In fact, politicization of identity and the expression of identity and ethnicity as a mobilization factor without proper liberalization and good governance and democratization could imperil the unity and national cohesion. To that end the next should be improving good governance and democratic rule. People at the helm of power need to put a great deal of thinking on how to create a political framework that allows simultaneously the evolution a common identity and the maintenance of cultural diversity.

Global powers need to understand that the Horn of Africa is unique in Africa because conflicts in the region tend to be protracted, intractable and unmanageable. Global powers tend to favor conducting their regional objectives with the support of or through pivot states in different regions. In this regard, the USA has relied on Ethiopia in GWoT in the Horn of Africa. The emerging power of Ethiopia should offer hope for conflict resolution. Its economic project in the form of infrastructural development and energy diplomacy carries the potential to integrate almost all the countries of the region. 
This research also has theoretical relevance. IR theories tend to overgeneralize mostly drawing from European and North American experiences. State behaviors and interactions are assumed to be the same across different geographical areas. The turn towards the regional level of analysis helps to expose the limitations of this notion. Ethiopia is an important case study in IR. First, it is a rising power in a conflict-ridden region, presenting itself as a 'benevolent hegemon'. Second, due to its IR's eurocentrism there is a deficit of attention to Africa which explains inability to adequately address African experiences. Africa has often been neglected by the different theoretical approaches in IR, and more generally by the discipline itself. Third, findings of this case study can be used to investigate regional powers in other parts of Africa. A potential area is a national level study of countries such as Rwanda (Great Lakes region) South Africa (Southern Africa) and Nigeria (Nigeria) to make sense of their influence in their sub-region. Fourth, the approach building bridge between comparative politics and international relations. It is a study of national politics, a domain of comparative politics, and its implications on the conduct of foreign policy and international politics. 


\section{BIBLIOGRAPHY}

Aalen, L. \& Muriaas, R. L. (2017). Manipulating Political Decentralisation: Africa's Inclusive Autocrats. New York: Routledge.

Abbink, J. (2011). Ethnic-based Federalism and Ethnicity in Ethiopia: Reassessing the Experiment after 20 years. Journal of Modern African studies, Volume 5, issue 4 (November 2011) pp. 596-618.

(2009). The Total Somali Clan Genealogy (Second Edition). ASC Working Paper 84/2009). African Studies Center: Leiden, The Netherlands. Monograph.

(2003). Ethiopia - Eritrea: proxy wars and prospects of peace in the horn of Africa. Journal of Contemporary African Studies, 21:3, 407-426.

(1998). Briefing: The Eritrean-Ethiopian Border Dispute. African Affairs, Vol. 97, No. 389, (Oct. 1998), pp. 551-565.

(1998). An Historical-Anthropological Approach to Islam in Ethiopia: Issues of Identity and Politics. Journal of African Cultural Studies, Vol. 11, No. 2, (Dec., 1998), pp. 109-124.

Abir, M. (1970). Education and National Unity in Ethiopia. African Affairs, Vol. 69, No. 274 (Jan. 1970), pp. 44-59.

Achraya, A. (2007). The Emerging Regional Architecture of World Politics. World Politics, 59:4, pp. 629-52.

Adebajo, A. \& Landsberg, C. (2003). South Africa and Nigeria as Regional Hegemons. In Mwesiga L. B. \& C. Landsberg (eds.). From Cape to Congo: Southern Africa's Evolving Security Challenges (pp. 171-204). Boulder: Lynne Rienner.

Adhanom, T (2015). "Ethiopia's Foreign Policy: Regional Integration and International Priorities", Africa Programme Meeting Transcript, Chatham House. Available at:

Adler, E. et al (eds) (2006). The Convergence of Civilizations? Constructing a Mediterranean Region. Toronto: University of Toronto Press.

AfDB (2016). African Statistical Yearbook 2016. Available at https://www.afdb.org/fileadmin/uploads/afdb/Documents/Publications/Afric an Statistical Yearbook 2016.pdf 
(2015). AfDB Annual Report 2015. Available at https://www.afdb.org/fileadmin/uploads/afdb/Documents/GenericDocuments/Annual Report 2015 EN - Full.pdf

Africa Intelligence (1999) "Aideed Factions Ditches Eritrea", http://www.africaintelligence.com/lON/politics-power/regionaldiplomacy/1999/12/11/aideed-faction-ditches-olf,58991-ART

African Manager (2013). Ethiopia,s grand plans for regional power distribution. African Manager. 2013, October 31. Retrieved from https://linkgalecom.ezproxy.fiu.edu/apps/doc/A347717036/AONE?u=miam11506\&sid=A ONE\&xid=04f65a13

Agence France Press (1999). Somali Factions Establish New Alliance. Available at: http://reliefweb.int/report/somalia/somali-factions-establish-new-alliance [accessed December 21, 2015]

Ahmad, A. (2009). Taliban and the Islamic Courts Union: How They Changed the Game in Afghanistan and Somalia? Policy Perspectives, Vol. 6, No. 2 (July - December 2009), pp. 55-72.

Aluko, O. (1977). The determinants of the foreign policies of African states. In O. Aluko (Ed.). The Foreign Policies of African States (pp. 1-23). Toronto: Hodder \& Stoughton.

Anderson, D. M. \& Mc Knight, J. (2014). Kenya At War: Al-Shabaab And Its Enemies in Eastern Africa. African Affairs, 114/454, 1-27.

Arieff, A. (2008). De Facto Statehood? The Strange Case of Somaliland. Yale Journal of International Affairs, Volume 3, Issue 2-Spring/Summer.

(2011). The Horn of Africa Security Complex. In R. Sharamo and B. Mesfin (eds.). Regional Security in the Post-Cold War Horn of Africa. Addis Ababa: Institute for Security Studies.

Art, R. J. (2009). The Fungibility of Force. In R. J. Art and K. N. Waltz (eds.). The Use of Force: Military Power and International Politics (pp. 1-22). Lanham: Rowman \& Littlefield.

Ayele, N. (1977). The foreign policy of Ethiopia. In O. Aluko (ed). The Foreign Policies of African States. London, Hodder and Stoughton.

Ayoob, M. (ed) (1986). Regional Security in the Third World: Case Studies from Southeast Asia and the Middle East. Boulder: Westview Press. 
Baldwin, D. A. (2016). Power and International Relations: A Conceptual Approach. Princeton: Princeton University Press.

Barnes, C. and Hasan, H. (2007). The Rise and Fall of Mogadishu's Islamic Courts. Journal of Eastern African Studies, 1:2, 151-160.

BBC (2010). Somali militants threaten World Cup TV viewers. 14 June 2010. http://www.bbc.com/news/10307512

(2007). "Helicopter shot down in Somalia", Friday, 30 March 2007 http://news.bbc.co.uk/2/hi/africa/6509729.stm

(2007). Foreign minister says Ethiopia transformed to regional, continental power BBC Monitoring International Reports Section: Africa, Newswire, June 14, 2007. https://infoweb-newsbankcom.ezproxy.fiu.edu/apps/news/documentview? $\mathrm{p}=$ WORLDNEWS\&docref=news/119C9D3C117B4BC8

(2005). "Exiled MPS return home to Somalia". 2 February 2005. Available at http://news.bbc.co.uk/2/hi/africa/4229345.stm

(2000). Government in exile for Somalia? Monday 24 July 2000 http://news.bbc.co.uk/2/hi/africa/849382.stm

(1999). "Ethiopia declares victory", March 1, 1999, http://news.bbc.co.uk/2/hi/africa/287736.stm

Bodung, S. (2014). "Regions, Powers and Order: A Structural Approach to Regional Politics". A Dissertation Submitted to the Faculty of the School of Government and Public Policy in Partial Fulfilment of the Requirements for the Degree of Doctor of Philosophy in the Graduate College, The University of Arizona 2014. http://hdl.handle.net/10150/337267

Bryden, M. (2013). "Somalia Redux? Assessing the New Somali Federal Government" A Report of the CSIS Africa Program August 2013.

(1999). New Hope for Somalia? The Building Block Approach. Review of African Political Economy, Vol. 26, No. 79, Africa and the Drugs Trade (Mar., 1999), pp. 134-140.

Bekele, D. (1982). "Peasant Associations and Agrarian Reform in Ethiopia". Bulletin, 982, vol. 13 no. 4, Institute of Development Studies, Sussex. Available at https://opendocs.ids.ac.uk/opendocs/bitstream/handle/123456789/10669/1 DSB $13 \quad 4 \quad 10.1111$-j.17595436.1982.mp13004009.x.pdf?sequence $=1$ \&isAllowed $=\mathbf{y}$ 
Bereketeab, R. (2012). Intergovernmental Authority on Development (IGAD): a critical analysis. In K. Mengisteab and R. Bereketeab (Eds.) Regional integration, identity and citizenship in the Greater Horn of Africa. (pp. 17394). Rochester, NY: James Currey.

Berhe, M. G. (2017). The Ethiopian Post-Transition Security Sector Reform Experience: Building a National Army from a Revolutionary Democratic Army. African Security Review, 26:2, 161-179.

Buzan, B. and Wæver, O. (2003). Regions and Powers. The Structure of International Security. Cambridge: Cambridge University Press.

Buzan, B., Waiver, O. \& De Wilde, J. (1998). Security: A New Framework for Analysis. Boulder: Lynne Rienner Publishers.

Canada: Immigration and Refugee Board of Canada (2001). Ethiopia: Peace Agreement between Ethiopia and Eritrea signed on 12 December 2000 in Algiers including terms, amnesty for deserters/evaders and or objectors to military service during the war (1998-2000), and for ethnic Eritreans detained and/or deported from Ethiopia, 16 February 2001, http://www.refworld.org/docid/3df4be2e14.html [accessed 29 January 2016]

Castagno, A. A. (1964). The Somali-Kenyan Controversy: Implications for the Future. Journal of Modern African Studies, Vol. 2, No. 2 (Jul., 1964), pp. 165-188.

Cheru, F. and Rekisa Z. S. (2019). Ethiopia's 'economic diplomacy' and regional integration. In F. Cheru, C. Cramer, \& A. Oqubay (Eds.). The Oxford Handbook of the Ethiopian Economy. Oxford: Oxford University Press.

Cheru, F., Tronvoll, K., Gebreluel, G. \& Feyissa. D. (2017). Ethiopia: The Rise of a Regional Hegemon. London: Zed Books.

Christensen, T. J. (1996). Useful Adversaries: Grand Strategy, Domestic Mobilization and Sino-American Conflict, 1947-1958. Princeton: Princeton University Press.

Clapham, C. (2017). The Horn of Africa: State Formation and Decay. Oxford: Oxford University Press.

(2013). Why is the Horn different? Rift Valley Review, 2013, http://riftvalley.net/news/whyhorn-different\#.W08KO7gyXIU

(2009). Post-war Ethiopia: The Trajectories of Crisis. Review of African Political Economy, 36: 120, 181-192. 
(2006). Ethiopia. In C. Clapham, J. Herbst, \& G. Mills (eds.). Big African States. Johannesburg: Wits University Press.

(2004). The challenge of democratization in Ethiopia. Whitehall Papers, 62: 1, 71-82.

(1994). Ethnicity and the National Question in Ethiopia. In P. Woodward \& M. Forsyth. Conflict and Peace in the Horn of Africa: Federalism and Its Alternatives. Dartmouth: Aldershot. Pp. 27-40

(1989). The State and Revolution in Ethiopia. Review of African Political Economy, No. 44, Ethiopia: 15 Years on. (1989), pp. 4-17.

(1987). Transformation and Continuity in Revolutionary Ethiopia. Cambridge: Cambridge University Press.

(n.d). From Haile-Selassie to Meles: Government, People and the Nationalities Question in Ethiopia. In S. Pausewang (ed.). Exploring New Political Alternatives for the Oromo in Ethiopia: Report from Oromo workshop and its after-effects Christian Michelson Institute CMI (pp. 14-19).

Clapham, C., Herbst, J. and Mills, G. (eds.) (2006) Big African States. Johannesburg: Wits University Press.

Cliffe, L. et al. (2009). Conflict and Peace in the Horn of Africa. Review of African Political Economy, vol. 36, no. 120.

Cliffe, L. (2008). Eritrea 2008: The Unfinished Business of Liberation. Review of African Political Economy, 35:116, 323-330.

Ciliers, J, Schünemann, J. \& Moyer, J. D. (2015) "Power and influence in Africa: Algeria, Egypt, Ethiopia, Nigeria and South Africa". African Futures Paper. March 2015. Institute for Security Studies. Frederick S. Pardee Center for International Futures.

Cline, K. et al (2011). Identifying Regional Powers and Their Status. In T. J. Volgy et al. (Eds.). Major Powers and the Quest for Status in International Politics: Global and Regional Perspectives (pp. 133-158). New York: Palgrave Macmillan.

Cohen, G. (2006). The Development of Regional \& Local Languages in Ethiopia's Federal System. In David Turton (Ed.). Ethnic Federalism: The Ethiopian Experience (pp. 165 - 180). Ohio: James Curry.

Cooper, A. F. and Antkiewicz, A. (2008). Emerging Powers in Global Governance. Lessons from the Heiligendamm Process. Waterloo: Wilfrid Laurier University Press. 
Crisis Group (2007). Ethiopia and Eritrea: stopping the slide to war, Africa Briefing, No. 48.

(2006). Can the Somali Crisis be Contained? Africa Report No.116.

(2003). Negotiating A Blueprint for Peace in Somalia. ICG Africa Report N59, Mogadishu/Brussels. 6 March 2003.

(2004). Biting the Somali Bullet. ICG Africa Report $N^{\circ} 79$ Nairobi/Brussels. 4 May 2004.

(2006). Somalia Conflict Risk Alert, 27 November 2006.

Cuesta-Fernández, I. (2015). Mammoth Dams, Lean Neighours: Assessing the Bid to Turn Ethiopia into East Africa's Powerhouse. In S. Scholvin (ed.). A New Scramble for Africa? (pp. 93-110). Farnham: Ashgate, 2015.

De Waal, A. (2015). The real politics of the Horn of Africa: Money, War, and the Business of Power. Cambridge: Polity Press.

(2004). The Politics of Destabilization in the Horn, 1989-2001. In Alex de Waal (ed.) Islamism and its Enemies in the Horn of Africa. Addis Ababa: Shama Books.

Dehez, D. (2008). Ethiopia - A Hegemon in the Horn of Africa Region? Paper for BISA Annual Conference, 15-17 December 2008. University of Exeter, UK.

Denden (nd). "AU High Level Delegation Proposals for a Framework Agreement For a Peaceful Settlement of the Dispute between Eritrea and Ethiopia", http://www.denden.com/Conflict/un-oau/oau-framework-11-98.htm

Dersso, S. A. (2013). Contributor Profile: Ethiopia. Brief for the Institute for Security Studies, Addis Ababa Office.

Destradi, S. (2008). Empire, Hegemony, and Leadership: Developing a Research Framework for the Study of Regional Powers. German Institute of Global and Area Studies Working Paper no. 79.

(2010). Regional Powers and Their Strategies: Empire, Hegemony, and Leadership. Review of International Studies, 36, pp 903-930.

Doornbos, M. (2002). Somalia: Alternative Scenarios for Political Reconstruction. African Affairs, Vol. 101, No. 402 (Jan., 2002), pp. 93-107.

Dowden R. (2012). Meles Zenawi interview excerpts: Unlike all previous governments our writ runs in every village. African Arguments. MAY 25, 2012. Available at https://africanarguments.org/2012/05/25/unlike-all- 
previous-governments-our-writ-runs-in-every-village-excerpts-from-aninterview-with-meles-zenawi-by-richard-dowden/

The Economist. (2016). 'Ethiopia Opens Africa's Tallest and most Controversial Dam.' The Economist, 21 December. https://www.economist.com/middleeast-and-africa/2016/12/21/217thiopia-opens-africastallest-and-mostcontroversial-dam.

EEBC (nd). "Decision Regarding Delimitation of the Border between The State of Eritrea and The Federal Democratic Republic of Ethiopia", http://www.refworld.org/pdfid/4a54bbec0.pdf

Elliot, A \& Holzer, G. S. (2009). The invention of 'terrorism' in Somalia: paradigms and policy in US foreign relations. South African Journal of International Affairs, 16:2, 215-244.

Fawn, R. (2009). Regions' and their study: wherefrom, what for and where to? Review of International Studies, 35:1, pp. 5-34.

Federal Democratic Republic of Ethiopia (1995). The Constitution of the Federal Democratic Republic of Ethiopia, Federal Negarit Gazetta, $2^{\text {nd }}$ year, no. 27.

(2002). The Federal Democratic Republic of Ethiopia Foreign Affairs and National Security Policy and Strategy. Addis Ababa: Ministry of Information.

http://www.erca.gov.et/images/Documents/Declaration Forms/Policy Doc uments/Foreign-English-Policy.pdf

(2003). A Proclamation to Provide for the Establishment of the Ethiopian National Security Council, Federal Negarit Gazetta, $7^{\text {th }}$ Year, no. 257, Addis Ababa.

Feyissa, D. (2008). "The Ethnic Self and the National Other: Anywaa Identity Politics in Reference to the Ethiopian State System." In Bahru Zewde (Ed.) Society State and Identity in African History (pp. 123-154) Addis Ababa: Association of African Historians/ Forum for Social Studies.

Fick, M. (2019). "Ethiopia's surveillance network crumbles, meaning less fear and less control". Reuters, UK - Special Reports. December 17, 2019. https://uk.reuters.com/article/uk-ethiopia-politics-surveillanceinsigh/ethiopias-surveillance-network-crumbles-meaning-less-fear-andless-control-idUKKBN1YL1BS

Fiseha, A. (2007). Federalism and the Accommodation of Diversity in Ethiopia: A Comparative Study. Wolf Legal Publishers: Nijmegen - Netherlands. 
Fiseha, A. \& Gebresilassie, F. H. (2019). The Interface between Federalism and Development in Ethiopia. In F. Cheru, C. Cramer, and A. Oqubay (Eds.). The Oxford Handbook of the Ethiopian Economy. Oxford: Oxford University Press.

Flemes, D. (2007). Conceptualizing Regional Power in International Relations: Lessons from the South African Case. German Institute of Global and Area Studies Working Paper no. 53.

Flemes, D. (ed.) (2010). Regional Leadership in the Global System: Ideas, Interests and Strategies of Regional Powers. Aldershot: Ashgate.

Flemes, D. \& Nolte, D. (2010). Introduction. In D. Flemes (ed.). Regional Leadership in the Global System: Ideas, Interests and Strategies of Regional Powers (pp. 1-14). Ashgate: Surrey/Burlington.

Firsing, Scott (2014). Thinking through the role of Africa's militaries in peacekeeping: the cases of Nigeria, Ethiopia and Rwanda. South African Journal of International Affairs, 21: 1, 45-67.

Fry, J. D. (2017). Ethiopian Exceptionalism and the Eritrea-Ethiopia Boundary Commission. African Journal of International and Comparative Law, 25(2), 135-157.

Furtig, H. (20144) Regional Powers in the Middle East: New Constellations after the Arab Revolt. New York: Palgrave McMillan.

Gebissa, E. (2002). The Italian Invasion, the Ethiopian Empire, and Oromo Nationalism: The Significance of the Western Oromo Confederation of 1936. Northeast African Studies, New Series, Vol. 9, No. 3, Special Issue: The Oromo in Ethiopian Studies: Confronting Challenges to Politically Engaged Scholarship (2002), 75 - 96.

Gebrekidan, F. (2012). From Adwa to OAU: Ethiopia and the Politics of PanAfricanism, 1896-1963. International Journal of Ethiopian Studies, Vol. 6, No. $1 / 2$ (2012), 71-86.

Gebreleul, G. (2014). Ethiopia's Grand Renaissance Dam: Ending Africa's Oldest Geopolitical Rivalry? The Washington Quarterly (Summer 2014) 37(2), 2537.

Gebrewold, B. (2014). Legitimate Regional Powers? A Failed Test for Ethiopia, Nigeria, and South Africa. African Security 7 (1), 1-23.

Gibert, Marie (2006) "The European Union in the IGAD-Sub region: Insights from Sudan and Somalia", Review of African Political Economy, vol. 33, no. 107. 
Gilkes, P. (2000). "Deception and Deceit- media coverage and comment on the Ethio- Eritrean conflict 1998 - 2000", Paper presented to the $14^{\text {th }}$ International Conference of Ethiopian Studies, Addis Ababa, November 2000.

(1998). Why? The Eritrean-Ethiopian conflict. Review of African Political Economy, 25:77, 508-526.

(1989). Somalia: Conflicts within and against the Military Regime. Review of African Political Economy, No. 44, Ethiopia: 15 Years on (1989), 53-58.

Gilkes, Patrick \& Martin Plaut (2000) "War in the Horn", Discussion Paper 82, London: Royal Institute of International Affairs.

Gray, G. (2006). The Eritrea/Ethiopia Claims Commission Oversteps Its Boundaries: A Partial Award? The European Journal of International Law Vol. 17 no.4., 699-721.

Guglielmo, M. (2006). Eritrea: What Regional Policy? Journal of Middle Eastern Geopolitics, Vol. 1, no. 5-6.

Godehardt, N. \& Nabers, D. (2011). Regional Powers and Regional Orders. London and New York: Routledge.

Hailemariam, Dessalegn (2016). The Speech of H.E. Prime Minister Hailemariam Dessalegn at the $71^{\text {st }}$ session of the United Nations General Assembly. https://www.ethioembassy.org.u.k/prime-minister-hailemariam-desalegnspeaking-at-the- $71^{\text {st-un-general-assembly/ }}$

Halliday, F. \& Molyneux, M. (1981). The Ethiopian Revolution. London, Verso.

Hansen, J. (2012). The Changing Political and Security Situation in Somalia: AlShabaab and Al-Qaeda. A paper commissioned by the Institute for Near East and Gulf Military Analysis (INEGMA).

Harbeson, J. W. (1988). The Ethiopian Transformation; The Quest for the PostImperial State. Boulder and London; Westview Press.

Healy, S. (2011a) "Hostage to Conflict Prospects for Building Regional Economic Cooperation in the Horn of Africa", A Chatham House Report. October 2011.

(2011b). "Seeking Peace and Security in the Horn of Africa: The Contribution of the Role of Regional Powers in the Field of Peace and Security: The Case of Ethiopia 36 German Institute of Global and Area Studies in Hamburg, Germany. 
(2008). Lost Opportunities in the Horn of Africa: How Conflicts Connect and Peace Agreements Unravel. London: Chatham House.

(2007). "Conflict in the Ogaden and Its Regional Dimension", A Horn of Africa Group, Chatham House Friday 31 August 2007

Hentz, J. J., and Boas, M. (eds) (2003). New and Critical Security and Regionalism: Beyond the Nation State. Hampshire, UK: Ashgate.

Henze, P. (2000). Layers of Time: A History of Ethiopia. New York: Palgrave.

(1994). The Economic Dimensions of Federalism in the Horn of Africa. In P. Woodward and M. Forsyth (Eds.). Conflict and Peace in the Horn of Africa: Federalism and Its Alternatives (pp. 124-130). Dartmouth: Aldershot.

Herbst, J. (2000). Western and African Peacekeepers: Motives and Opportunities. J. W. Harbeson and D. Rothchild (Eds.). Africa in World Politics. The African State System in Flux (pp. 308-328). Oxford, Westview.

Hiwet, A. (1984). Analysing the Ethiopian Revolution. Review of African Political Economy, No. 30, Conflict in the Horn of Africa. (Sep., 1984), 32-47.

Hobson, J. (2003). The State and International Relations. New York: Cambridge University Press.

Howard, M. (1979). War and the Nation-State. Daedalus, 108(4), 101-110.

Hull C. B. and Sahal A. (2007). Ethiopian troops to stay in Somalia weeks, Reuters - AlertNet. 02 Jan 2007. http://reliefweb.int/report/somalia/ethiopian-troopsstay-somalia-weeks.

Human Rights Watch (2008). "So Much to Fear: War Crimes and the Devastation of Somalia", December 8, 2008, https://www.hrw.org/report/2008/12/08/somuch-fear/war-crimes-and-devastation-somalia

Hurrell, A. (2007). One world? Many worlds? The place of regions in the study of international society. International Affairs, 83:1, 127-46.

(2006). Hegemony, liberalism and global order: what space for wouldbe great powers? International Affairs, 82:1, 1-19.

IGAD (2002). Proceedings of the $9^{\text {th }}$ Summit of the Assembly of Heads of State and Government of the Intergovernmental Authority on Development (IGAD), 10-11 January 2002, Khartoum, Republic of Sudan. https://www.issafrica.org/uploads/9THSUMMITFINALREPORT.PDF 
(1999). The Proceedings of the $7^{\text {th }}$ summit of IGAD Assembly Heads of State and Government Djibouti, Republic of Djibouti, 26 November 1999. https://www.issafrica.org/uploads/7THSUMMI.PDF)

IISS (2017). Chapter Nine: Sub-Saharan Africa. The Military Balance, 117:1, 479548.

(2016). Chapter Nine: Sub-Saharan Africa. The Military Balance, 116:1, 421480.

(2016). Chapter Ten: Country comparisons - commitments, force levels and economics. The Military Balance, 116:1, 481-492,

(2015). Chapter Nine: Sub-Saharan Africa. The Military Balance, 115:1, 421480.

(2015). Chapter Ten Country comparisons - commitments, force levels and economics. The Military Balance, 115:1, 481-492.

(2014). Chapter Ten: Country comparisons - commitments, force levels and economics". The Military Balance, 114:1, 471-492.

IMF (2017). "World Economic Outlook - 1980 - 2020". http://www.imf.org/external/pubs/ft/weo/2017/01/weodata/index.aspx

Mohamed H. I. (2018). From Al-Itihaad to Al-Shabaab: how the Ethiopian intervention and the 'War on Terror' exacerbated the conflict in Somalia. Third World Quarterly, 39(11), 2033-2052.

IRIN (2008). "Urgent need for dialogue after departure of UNMEE, says analyst" 1 August 2008. http://www.irinnews.org/report/79573/ethiopia-eritrea-urgentneed-dialogue-after-departure-unmee-says-analyst

(2004). "Gov't welcomes US statement, but calls for positive action", $28 \quad$ January 2004, https://www.thenewhumanitarian.org/report/48309/eritrea-govt-welcomesus-statement-calls-positive-action

(2004). "End the impasse, British envoy urges", 20 January 2004, https://www.thenewhumanitarian.org/news/2004/01/20-0

(2004). "Security Council re-affirms full support for peace process", 22 November 2004. http://www.irinnews.org/fr/node/219799

(2003). "Interview with President Ismail Omar Guelleh" (http://www.irinnews.org/report/46957/djibouti-interviewpresident-ismail-omar-guelleh) 
(2003). Ethiopia says Djibouti Pull out will have I impact. 29 September 2003. http://www.irinnews.org/fr/node/214339

(2003). "Horn anti-terror axis formed", 29 December 2003, https://www.thenewhumanitarian.org/report/47826/ethiopia-horn-antiterror-axis-formed

(2002). Reconciliation conference set for April, NAIROBI, 15 February 2002. Available at http://www.irinnews.org/report/30280/somaliareconciliation-conference-set-april [Accessed on February 13, 2016]

(2002). "Boundary Commission rejects Ethiopian review request" 1 July 2002.http://www.irinnews.org/report/32746/eritrea-ethiopia-boundarycommission-rejects-ethiopian-review-request

(2002). "Reconciliation conference set for April". 15 February 2002. http://www.irinnews.org/report/30280/somalia-reconciliation-conferenceset-april

(2001). "Ethiopia - Somalia: An uneasy relationship https://www.thenewhumanitarian.org/report/16449/ethiopia-somaliauneasy-relationship

(2000). A regional power 27 July 2000 https://www.thenewhumanitarian.org/report/3305/ethiopia-regional-power

(1999). “Are Building Blocks the Solution?"News 17 July 1999. https://www.thenewhumanitarian.org/news/1999/07/17/are-buildingblocks-solution

lyob, R. (2000). The Ethiopian-Eritrean Conflict: Diasporic vs. Hegemonic States in the Horn of Africa, 1991-2000. The Journal of Modern African Studies, 38(4), 659-682.

(1993). Regional Hegemony: Domination and Resistance in the Horn of Africa. Journal of Modern African Studies, vol. 31, no. 2.

Jackson, D. R. (2010). The Ogaden War and the Demise of Détente. The Annals of the American Academy of Political and Social Science Vol. 632, Perspectives on Africa and the World (November 2010), 26-40.

Jhazbhay, I. (2009). "Somaliland: The Journey of Resistance, Reconciliation and Peace" African Safety and Peace Journal. http://www.unisa.ac.za/contents/faculties/humanities/sosw/docs/ASPJ2009/ASPJ2009-7-1-04-Somaliland-The-journey-of-resistancereconciliation-and-peace.pdf 
Kappel, R. (2011). On the Economics of Regional Powers. In N. Godehardt \& D. Nabers (eds.). Regional Powers and Regional Orders (pp. 68-92). New York: Routledge.

Katzenstein, P. J. (2005). A World of Regions: Asia and Europe in the American Imperium. Ithaca, NY: Cornell University Press.

Keller, E. (1998). Regime Change and Ethno-regionalism in Ethiopia - the Case of the Oromo. In Asafa Jalata (Ed.). Oromo Nationalism and the Ethiopian Discourse (pp. 109 - 124). Red Sea Press: Lawrencevillee NJ.

Keller, E. J., And Rothchild, D. (eds) (1996). Africa in the New International Order: Rethinking State Sovereignty and Regional Security. Boulder: Lynne Rienner Publishers.

Kornprobst M. (2002). The management of border disputes in African regional subsystems: comparing West Africa and the Horn of Africa. Journal of Modern African Studies, 40:3, 369-393.

Kugler, J. and Arbetman M. (1989). Choosing among measures of power: A review of the empirical record". In R. J. Stoll and M. D. Ward (eds.) Power in World Politics. Boulder, CO: Lynn Rienner.

Lacey, M. (2005). Eritrea Expels U.N. Peacekeepers, Increasing Tension with Ethiopia. The New York Time. DEC. 8, 2005. http://www.nytimes.com/2005/12/08/world/africa/eritrea-expels-unpeacekeepers-increasing-tension-with-ethiopia.html? $\mathrm{r}=1$

Lake, D. A. (2009). Regional Hierarchy: Authority and Local International Order. Review of International Studies, 35, 35-58.

Lake, D. and Morgan, P. (eds) (1997). Regional Orders: Building Security in a New World. University Park: Pennsylvania State University Press.

Le Gouriellec, S. (2018). Regional power and contested hierarchy: Ethiopia, an 'imperfect hegemon' in the Horn of Africa. International Affairs, Volume 94, Issue 5, September 2018, 1059-1075.

Le Sage, A. (2001). Prospects for Al-Itihaad \& Islamist Radicalism in Somalia. Review of African Political Economy, Vol. 28, No. 89, State of the Union: Africa in 2001 (Sep., 2001), 472-477.

Lefort, R. (1983). Ethiopia: An Heretical Revolution. London: Zed Books.

Lemke, D. (2010). Dimensions of Hard Power: Regional Leadership and Material Capabilities. In Flemes, Daniel (ed). Regional Leadership in the Global 
System: Ideas, Interests and Strategies of Regional Powers (pp. 1-14). Ashgate: Surrey/Burlington.

(2002). Regions of War and Peace. Cambridge: University of Cambridge Press.

Levine, D. N. (2011). Ethiopia's nationhood reconsidered. Análise Social, Vol. 46, No. 199 (2011), 311-327.

Lewis, I.M (2008). Understanding Somalia and Somaliland: Culture, History and Society. London: Hurst and Company.

(1999). A Pastoral Democracy: A Study of Pastoralism and Politics Among the Northern Somali of the Horn of Africa. Münster: LIT Verlag.

(1989). The Ogaden and the Fragility of Somali Segmentary Nationalism. African Affairs, Vol. 88, No. 353 (Oct., 1989), 573-579.

(1982). "Somalia: Nationalism Turned inside out". MERIP Reports, No. 106, Horn of Africa: The Coming Storm (Jun., 1982), pp. 16-21.

(1967). Recent Developments in the Somali Dispute. African Affairs Vol. 66, No. 263 (Apr., 1967), 104-112.

Lobell S. E. et al (2009). Neoclassical Realism, the State and Foreign Policy. Cambridge: Cambridge University Press.

Lyons, T. (2009). The Ethiopia-Eritrea Conflict and the Search for Peace in the Horn of Africa. Review of African Political Economy, 36: 120, 167-180.

Mahoney, J and Thelen, K. (2010). Explaining Institutional Change: Ambiguity, Agency and Power. New York: Cambridge University Press.

Mahoney, J. (2000). Path Dependency in Historical Institutionalism. Theory and Society, 29: $507-548$.

Makonnen, T. and Lulie H. (2014). "Ethiopia, Regional Integration and the COMESA Free Trade Area". South African Institute of International Affairs, Occasional Paper 198, Economic Diplomacy Programme, August 2014.

Manson, K. (2014). Energy exports drive Ethiopia regional power hopes. Financial Times, p. 4 . Retrieved from https://link-galecom.ezproxy.fiu.edu/apps/doc/A358806081/AONE?u=miam11506\&sid=A ONE\&xid=fc502e0a 
Marchal, R. (2004). "Islamic Political Dynamics in the Somali Civil War: Before and After September 11". Alex de Waal (ed.). Islamism and its Enemies in the Horn of Africa. Addis Ababa: Shama Books.

Marcus, H. (1974). The Life and Times of Menelik: Ethiopia 1844 - 1913. Oxford: Clarendon Press.

Markakis, J. (2011). Ethiopia: The Last Two Frontiers. Woodbridge, Suffolk; Rochester, NY: Boydell \& Brewer.

(2020). The Legacy of the Past on Ethiopia's Modern Political Life. Review of African Political Economy. http://roape.net/2020/03/12/thelegacy-of-the-past-on-ethiopias-modern-political-life/

Mennasemay, M. (1997). Adwa: A Dialogue between the Past and the Present. Northeast African Studies, New Series, Vol. 4, No. 2 (1997), 43-89.

Mengisteab, K. (2019). Federalism in Ethiopia's transformation. In F. Cheru, C. Cramer, and A. Oqubay (Eds.) The Oxford Handbook of the Ethiopian Economy. Oxford: Oxford University Press.

(2009). What has gone wrong with Eritrea's foreign policy. In R Reid (ed). Eritrea's External Relations. London: Royal Institute of International Affairs.

Menkhaus, K. (2006/2007). Governance without Government in Somalia Spoilers, State Building, and the Politics of Coping. International Security, Vol. 31, No. 3 (Winter, 2006/2007), 74-106.

(2007) The Crisis in Somalia: Tragedy in Five Acts. African Affairs, Vol. 106, No. 424 (Jul., 2007), 357-390.

Mesfin, B. (2012) Ethiopia's Role and Foreign Policy in the Horn of Africa. International Journal of Ethiopian Studies, Vol. 6, No. 1/2 (2012), 87-113.

Mulugeta, K. (2014). "The Role of Regional Powers in the Field of Peace and Security: The Case of Ethiopia." July 2014 Horn of Africa Security Dialogue, Frederich Eibert Stiftung https://library.fes.de/pdffiles/bueros/aethiopien/10879.pdf

Myers, D. J. (1991). Regional Hegemons: Threat Perception and Strategic Response. Boulder: Westview Press.

Mohammed, A. (2007). Ethiopia's Strategic Dilemma in the Horn of Africa; available at: http://hornofafrica.ssrc.org/Abdul Mohammed [accessed on January 23, 2016]. 
Moller, B. (2009). The Somali Conflict: The Role of External Actors. Copenhagen: Danish Institute for International Studies Report.

Mosley, J (2015). "Somalia's Federal Future Layered Agendas, Risks and Opportunities," Chatham House Africa Program, September 2015.

Murithi, T. (2009). Inter-governmental Authority on Development on the Ground: Comparing Interventions in Sudan and Somalia. African Security, 2:2-3, 136-157.

Nasr, H, and Neef, A. (2016). Ethiopia's Challenge to Egyptian Hegemony in the Nile River Basin: The Case of the Grand Ethiopian Renaissance Dam. Geopolitics, Vol. 21, No. 4, 969-989.

Negash, T. \& Tronvoll, K. (2000). Brothers at war: Making sense of the EritreanEthiopian war. Oxford: James Currey.

Nelson, M. B. (2016). Africa's Regional Powers and Climate Change Negotiations. Global Environmental Politics, 16:2, May 2016.

Neumann, I. B. (ed.) (1992). Regional Great Powers in International Politics. Basingstoke: St. Martin's Press.

New York Times (2000). “Warlords Won't Accept Somali Leader”. Sept. 32000 available at https://www.nytimes.com/2000/09/03/world/4-warlords-won-taccept-somali-leader.html

Nichiporuk, B (2000). The Security Dynamics of Demographic Factors. Washington DC: RAND Organization. http://www.rand.org/pubs/monograph reports/MR1088.html

Nolte, D (2010). How to Compare Regional Powers: Analytical Concepts and Research Topics. Review of International Studies, 36, 881-901.

(2007). How to Compare Regional Powers: Analytical Concepts and Research Topics. Presented at ECPR Joint Session of Workshops, Helsinki, 7-12 May.

Organization of African Unity Secretariat (1964). Resolutions Adopted by the First Ordinary Session of the Assembly of Heads of State and Government Held in Cairo, United Arab Republic, from 17 To 21 July 1964. Available at: https://www.issafrica.org/AF/RegOrg/unity to union/pdfs/oau/hog/bHoGA ssembly1964.pdf 
Ottaway, M. (1999). Africa. Foreign Policy, No. 114 (Spring, 1999), 13-25.

(1987). State power consolidation in Ethiopia. Afro-Marxist Regimes: Ideology and Public Policy. Boulder, Colorado, Lynne Rienner.

Ottaway, M. (Ed.) (1990). The Political Economy of Ethiopia. New York, Praeger.

Ottaway, M. and D. Ottaway (1978). Ethiopia: Empire in Revolution. New York, Africana Publishing Company.

Pasusewang, S. (1990) 'Meret Learashu'. In S. Pausewang et al. (Eds.) Ethiopia: Options for Rural Development (pp. 38-49). London and New Jersey: Zed Books.

Plaut, M. (2005) The Eritrean Opposition Moves toward Unity. Review of African Political Economy, 32, (106), 638-643.

(2001). Towards a Cold Peace? The Outcome of the Ethiopia-Eritrea War of 1988-2000. Review of African Political Economy, Vol. 28, No. 87, Civil Society, Kleptocracy \& Donor Agendas: What Future for Africa? (Mar., 2001), 125-129.

(1998). 'Yemen and Eritrea: Friends once more?', Review of African Political Economy, 78, (1998).

Poulha, E. (2004). The Power of Continuity: Ethiopia through the Eyes of its Children. Stockholm: Nordiska Afrikaninstitutet.

Pratt, M. (2006). "A terminal crisis? Examining the breakdown of the EritreaEthiopia boundary dispute resolution process", Conflict Management and Peace Science, 23, pp. 329-341.

Prys, M. (2010). The variability of regional powers; Paper presented at the SGIR $7^{\text {th }}$ Pan-European Conference on International Relations, Stockholm, 9-11 September 2010.

(2010). "Hegemony, Domination, Detachment: Differences in Regional Powerhood", International Studies Review (2010) 12, Analytical Essays: Evaluation, Synthesis, Reflection, 479-504. Regassa, Tsegaye (2010) "Comparative Relevance of the Ethiopian Federal System to other African Polities of the Horn: First Thoughts on the Possibility of "Exporting" Multiethnic Federalism", Bahir Dar University Journal of Law, Vol.1 No.1, 5- 48.

Reid, R. (2005). Caught in the Headlights of History: Eritrea, the EPLF, and the post-war nation-state. Journal of Modern African Studies, 43, 467-488.

Reuters (2008). "Somalia is worst humanitarian crisis- UN official", World Crises News, JANUARY 29, 2008, http://www.reuters.com/article/idUSL29531512. CH .2400 
Rice, X. (2009). Ethiopia ends Somalia occupation. The Guardian. Monday 26 January 2009.2 Available at: http://www.theguardian.com/world/2009/jan/26/ethiopia-ends-somaliaoccupation [Accessed on March 2, 2016]

Rose, G. (1998). Neoclassical Realism and Theories of Foreign Policy. World Politics 51:144-172.

Rosenthal, B. (2001). Ethiopia shows its hand in Somalia crisis. Agence FrancePresse. $\quad$ http://reliefweb.int/report/somalia/ethiopia-shows-its-handsomalia-crisis

Samatar, A. I. (2007). Ethiopian Invasion of Somalia, US Warlordism \& AU Shame. Review of African Political Economy, Vol. 34, No. 111, Debates on the Left in Southern Africa (Mar., 2007), 155-165.

Schlovin, S. (2014). The Geopolitics of Regional Power: Geography, Economics and Politics in Southern Africa. Surrey/Burlington: Ashgate.

Schweller, R. L. (2006). Unanswered Threats: Political Constraints on the Balance of Power. Princeton University Press.

(1998) Deadly Imbalances: Tripolarity and Hitler's Strategy of World Conquest. New York: Columbia University Press.

Shehim, K. (1985). Ethiopia, Revolution, and the Question of Nationalities: The Case of the Afar. The Journal of Modern African Studies, Vol. 23, No. 2 (Jun., 1985), 331-348.

SIPRI (2019). UN arms embargo on Somalia, SIPRI databases / Arms embargoes, https://www.sipri.org/databases/embargoes/un arms embargoes/somalia $\underline{2019}$

(2017). SIPRI Military Expenditure Database https://www.sipri.org/databases/milex

Skocpol, T. (1985). Bringing the state back in: strategies of analysis in current research. In P. B. Evans, D. Rueschemeyer, \& T. Skocpol (Eds). Bringing the State Back In (pp. 3-43). Cambridge: Cambridge University Press.

Smith, L. (2013). Making Citizens in Africa: Ethnicity, Gender and National Identity in Ethiopia. New York: Cambridge university press.

Spears, I. S. (2013). The Ethiopian Crisis and the Emergence of Ethiopia in a changing State System. In G. B. Strang (Ed.). Collision of Empires: Italy's Invasion of Ethiopia and its International Impact. Surrey/Burlington: Ashgate. pp. 33-52. 
Stewart-Ingersoll, R. and Frazier, D. (2012). Regional Powers and Security Orders: A Theoretical Framework. London: Routledge.

Sufi, M. A. (2003). The Future Political Order for the Federal States of Somalia. Northeast African Studies, Vol. 10, No. 3, The Horn of Africa between History, Law, and Politics, 281-288.

Tadesse, K. (1993). The Generation: The History of the Ethiopian People's Revolutionary Party. Trenton, N.J.: Red Sea Press.

Tadesse, M. (2015) Making sense of Ethiopia's regional influence. In G. Prunier and E. Ficquet (Eds). Understanding contemporary Ethiopia: monarchy, revolution and the legacy of Meles Zenawi. London: Hurst.

(2002). Al-Ittihad: Political Islam and Black Economy in Somalia. Addis Ababa: Mega Printing Enterprise.

(1999). The Eritrean-Ethiopia War: Retrospect and Prospect. Addis Ababa: Mega Printing Enterprise.

Tadesse, M. \& Young, J. (2003). TPLF: reform or decline? Review of African Political Economy, 30:97. 389-403.

Tafirenyika, M. (2015). The Changing Face of Ethiopia: An Assertive Nation Flexes its Economic Muscle. Africa Renewal, August 2015, https://www.un.org/africarenewal/magazine/august-2015/changing-faceethiopia

Tareke, G. (2011). The Ethiopian Revolution: War in the Horn of Africa. New Haven: Yale University Press.

(2000). The Ethiopia-Somalia War of 1977 Revisited, The International Journal of African Historical Studies, Vol. 33, No. 3 (2000), pp. 635-667.

(1991) Ethiopia: Power and Protest: Peasant Revolts in the 20 $0^{\text {th }}$ Century. Lawrenceville-New Jersey: Red Sea Press.

Tekalign, Y. (2019). Regional security dilemma for Ethiopia's quest for access to the sea. African Security Review, 28:3-4, 189-206.

Tekle, A. (1996). International Relations in the Horn of Africa (1991-96). Review of African Political Economy, Dec., 1996, Vol. 23, No. 70 (Dec., 1996), 499509.

Tellis, A. J. et al (2000). Measuring National Power in the Postindustrial Age: An Analysts Handbook. RAND Corporation Washington DC January 1, 2000. 
Thelen, K. (1999). Historical Institutionalism in Comparative Perspective. Annual Review of Political Science, 2: 369-404.

Tibebu, T. (1996). Ethiopia: The "Anomaly" and "Paradox" of Africa. Journal of Black Studies, Vol. 26, No. 4 (Mar., 1996), 414-430.

Tiruneh, A. (1993) The Ethiopian Revolution 1974 - 1987: A Transformation from an Aristocratic to a Totalitarian Autocracy. Cambridge: Cambridge University Press.

Tran, M. (2000). Ethiopia declares victory over Eritrea. Thursday 25 May 2000. Available at: http://www.theguardian.com/world/2000/may/25/ethiopia [Accessed on January 25, 2016]

Triulzi, A. (2008). "Adwa". In Prem Poddar et al (Eds.). A Historical Companion to Postcolonial Literatures - Continental Europe and its Empires. Edinburgh University Press.

Tronvoll, K. (2009). War and the Politics of Identity in Ethiopia: The Making of Enemies and Allies in the Horn of Africa. James Curry.

United Nations (2020). "United Nations Peacekeeping: Troops and Police Contribution", $\quad$ https://peacekeeping.un.org/en/troop-and-policecontributors

(2012). "Horn of Africa", Map No. 4188 Rev. 5, March 2012, Department of Field Support Cartographic Section, https://www.un.org/Depts/Cartographic/map/profile/horne.pdf

(2011). "Somalia", Map No. 3690 Rev. 10, December 2011, Department of Field Support Cartographic Section, https://www.un.org/Depts/Cartographic/map/profile/somalia.pdf

(2006). Security Council Approves African Protection, Training Mission in Somalia, Unanimously Adopting Resolution 1725 (2006) 6 December 2006, https://www.un.org/Press/en/2006/sc8887.doc.htm

(2000). Report of the Secretary-General on the situation in Somalia to the United Nations Security Council, http://www.un.org/en/ga/search/view doc.asp?symbol=S/2000/1211

(2000). Agreement on Cessation of Hostilities Between the Government of the Federal Democratic Republic of Ethiopia and the Government of the State of Eritrea, 18 August 2000, UN Treaty Series Volume 2138, I-37273, http://www, refworld.org/docid/4a54bbecd.html 
United Nations Conference on Trade and Development (2016). Merchandise: Intra-trade and extra-trade of country groups by product, annual 1995-2015. Available at http://unctadstat.unctad.org/wds/TableViewer/tableView.aspx

United Nations Development Programme (2015). Human Development Report 2015: Work for Human Development. Available at http://hdr.undp.org/sites/default/files/2015 human development report.pd f

United Nations Economic Commission for Africa (2016). The Demographic Profile of African Countries. March 2016. Available at http://www.uneca.org/sites/default/files/PublicationFiles/demographic profi le rev april 25.pdf

US Department of State (2008). Country Reports on Terrorism, Washington, DC: US Department of State.

Verhoeven, H. (2015). Africa's Next Hegemon: Behind Ethiopia's Power Plays. Foreign Affairs, April 2015, https://www.foreignaffairs.com/articles/ethiopia/2015-04-12/africas-next$\underline{\text { hegemon }}$

(2014). South Sudan Conflict Destabilizes Ethiopia's Regional Strategy. By: Verhoeven, Harry, World Politics Review http://eds.a.ebscohost.com.ezproxy.fiu.edu/eds/detail/detail?vid= 0\&sid=b96636af-cd01-454f-a15fc9e6463ca265\%40sessionmgr4008\&bdata $=$ JnNpdGU9ZWRzLWxpdmU\% $\underline{3 d \# A N=96289487 \& d b=e d o}$

(2013). The politics of African energy development: Ethiopia's hydroagricultural state-building strategy and clashing paradigms of water security. Philosophical Transactions, 2013, 1-16.

(2011). "Black Gold for Blue Gold? Sudan's Oil, Ethiopia's Water and Regional Integration" Chatham House: Africa Programme, Briefing Paper, June 2011.

Vinci, A. (2006). An analysis and comparison of armed groups in Somalia. African Security Review, 15:1, 75-90.

Walls, M. (2009). The Emergence of a Somali State: Building Peace from Civil War in Somaliland. African Affairs, 108(432), 1-19.

Waltz, K. (1979). Theory of International Politics. Reading/Massachusetts: Addison-Wesley. 
Warner, J. (2013). Eritrea's military unprofessionalism and US security assistance in the Horn of Africa. Small Wars \& Insurgencies, 24:4, 696-711.

Wax, E. and de Young, K. (2006). U.S. Secretly Backing Warlords in Somalia Washington Post Foreign Service Wednesday, May 17, 2006. http://www.washingtonpost.com/wpdyn/content/article/2006/05/16/AR2006051601625.html [Accessed on March 3, 2016]

Woldemariam, M. (1964). The Background of the Ethio-Somalian Boundary Dispute. The Journal of Modern African Studies, Vol. 2, No. 2 (Jul., 1964), 189-219.

Woldemariam M. (2018). Regional Powers, Great Power Allies, and International Institutions: The Case of Ethiopia. In J. Warner \& T. Shaw (Eds). African Foreign Policies in International Institutions. Contemporary African Political Economy. Palgrave Macmillan, New York.

Wohlforth, W. C. (1993). The Elusive Balance: Power and Perceptions during the Cold War. New York, Ithaca: Cornell University Press.

Woodward, P. (2012). Crisis in The Horn of Africa: Politics, Piracy and the Threat of Terror. London: I. B. Tauris.

World Bank (2017). Sudan. http://www.worldbank.org/en/country/sudan/overview

(2015). World Integrated Trade Solutions (http://wits.worldbank.org/CountryProfile/en/Country/ETH/Year/2015/Sum $\underline{\text { mary) }}$

Woubshet, D. (2010). Gleaning Ethiopia. Callaloo, 33(1), 199-202.

Yasin, M. Y. (2008). Political History of the Afar in Ethiopia and Eritrea. Africa Spectrum, Vol. 43, No. 1, Horn of Africa (2008), 39-65.

Yihun, B. B. (2014) Black Ethiopia: A Glimpse into African Diplomacy 1956- 1991. Los Angeles: Tsehai Publishers.

Young, J. (2007). Armed Groups Along Sudan's Eastern Frontier: An Overview and Analysis. Small Arms Survey, HSBA Working Paper 9. GenevaSwitzerland, The Small Arms Survey Graduate Institute of International Studies.

http://citeseerx.ist.psu.edu/viewdoc/download?doi=10.1.1.470.9395\&rep=r ep1\&type=pdf 
(1999). Along Ethiopia's Western Frontier: Gambella and Benishangul in Transition. The Journal of Modern African Studies, Vol. 37, No. 2 (Jun., 1999), pp. 321-346

(1997). Peasant Revolution in Ethiopia. Cambridge: Cambridge University Press.

(1996a) Ethnicity and Power in Ethiopia. Review of African Political Economy, Vol. 23, No. 70 (Dec., 1996), 531-542.

(1996b) The Tigray and Eritrean People's Liberation Fronts: a History of Tensions and Pragmatism. Journal of Modern African Studies, 34(1).

Záhořík, J. (2014). Ethiopia's Hegemony in the Horn of Africa: Internal Tensions and External Challenges Before and After Meles Zenawi. The Journal of the Middle East and Africa, 5:1, 23-38.

Zakaria, F. (1998). From Wealth to Power: The Unusual Origins of America's World Role. Princeton: Princeton University Press.

Zewde, B. (2014) A quest for socialist Ethiopia: The Ethiopian Student Movement c. 1960-1974. Melton, Suffolk, UK: James Currey.

Zimmerman, W. (1972) Hierarchical Regional Systems and the Politics of System Boundaries. International Organization, Vol. 26, No. 1 (Winter, 1972), 1836. 
VITA

YONAS MULAT

December 2020

December 2015

June 2010 - March 2011

April 2010 - March 2011

December 2000 - November 2009

January 2006 - December 2007

September 2004 - November 2006

December 2003

July 2000
Doctor of Philosophy (Political Science); Florida International University; Miami, FL. Expected.

Master of Arts (Political Science); Florida International University; Miami, FL.

Program Specialist - New African Research and Development Agency (NARDA); Monrovia, Liberia. Lecturer - University of Liberia Monrovia, Liberia.

Lecturer/Assistant Lecturer - Addis Ababa University; Addis Ababa, Ethiopia. Lecturer - Ethiopian Defense Command and Staff College; Addis Ababa, Ethiopia. Assistant Dean - College of Social Sciences, Addis Ababa University; Addis Ababa, Ethiopia.

Master of Arts (Development Studies); Erasmus University - Institute of Social Studies; The Hague, Netherlands. Bachelor of Arts (Political Science and International Relations); Addis Ababa University; Addis Ababa, Ethiopia.

\section{PUBLICATIONS AND PRESENTATIONS}

Mulat, Y. (2016) Domestic Sources of International Action: Ethiopia and the Global War on Terrorism. African Journal of Political Science and International Relations, Vol. 10(11), 131-144.

(2016) "Ethiopia: A Regional Power in the Making", Paper Presented at the $74^{\text {th }}$ Annual Midwestern Political Science Association (MPSA) Conference, Chicago, IL, April 7 - 10, 2016.

(2014) "Domestic Sources of International Action: Ethiopia and the Global War on Terrorism", Paper Presented at the Seventh Annual Conference of the Association for the Study of the Middle East and Africa (ASMEA) Washington DC, October 31 - November 1, 2014.

(2014) "The Domestic - International Nexus in Ethiopia's Role in the War on Terrorism", Paper presented at the 68th Annual Conference of the New York State Political Science Association (NYSPSA), New York City, April 25-26, 2014. 
(2006) Ethiopia: Politics, Policy and Development Issues. in Kassahun Berhanu et al (Eds). Attendant Issues in Agricultural Extension in Ethiopia. Addis Ababa: Addis Ababa University Press.

(2006) Post 1991 Agricultural Polices in Ethiopia. In Alexander Attilio et.al (eds.). Ethiopia: Politics, Policy Making and Rural development. Addis Ababa: Addis Ababa University Press. 